\title{
Highlighting the gaps in hazard and risk assessment of unregulated Endocrine Active Substances in surface waters: retinoids as a European case study
}

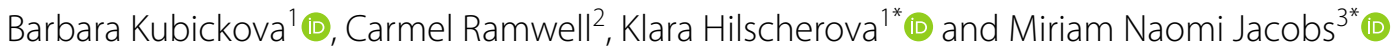

\begin{abstract}
Regulatory hazard and risk assessment of endocrine-active substances currently specifies four modes of action: interference with sex hormone (oestrogen, androgen) pathways, steroidogenesis, and thyroid hormone signalling. This does not encompass the full complexity of the endocrine system and its extended interfaces with environmental pollutants that can potentially disrupt the carefully maintained balance. Here we take the retinoid signalling pathway as a European case study for both, under- and unregulated endocrine pathways and outline the different levels of interference, discuss their adversity, and indicate crosstalk to other signalling pathways. Retinoid compounds already exist in drinking water sources, occur naturally in cyanobacterial blooms and/or enter surface waters via wastewater discharge, where they pose a potential hazard to the environment and human health - a situation that can be expected to worsen due to water shortages induced by climate-change and population growth. We briefly review relevant aspects of current endocrine disruptor (ED) testing for regulatory purposes and then expand upon the needs for inclusion of disruption of retinoid signalling in (ED) regulatory safety assessment contributing to adverse health outcomes that include cognitive function and neurological disease. An overview of developmental effects of retinoid signalling disruption across species highlights critical processes and potential crosstalk with other signalling pathways. A focused weight of evidence-based evaluation of the biologically plausible associations between neurological disorders and altered retinoid signalling highlights the evidence gaps. We show that monitoring only a limited number of anthropogenic priority chemicals in water is insufficient to address the environmental risks of retinoid signalling disruption. To comprehensively assess impacts on the endpoints, processes, and pathways of the endocrine system that are most vulnerable to chemical interference we need further investigation of the true mixture composition in environmental matrices. On a weight of evidence-basis this information can then be integrated into a reliable, inclusive, quantitative approach that ultimately accommodates all the critical pathways. By focusing on the retinoid signalling pathway, we intend to improve the scope and relevance of an integrated approach for the risk assessment of endocrine disruptors.
\end{abstract}

\footnotetext{
*Correspondence: klara.hilscherova@recetox.muni.cz; Miriam.Jacobs@phe.

gov.uk

${ }^{1}$ Masaryk University, Faculty of Science, RECETOX, Kamenice 753/5,

62500 Brno, Czech Republic

${ }^{3}$ Department of Toxicology, Centre for Radiation, Chemical

and Environmental, Hazards Public Health England, Chilton, Oxfordshire,

UK

Full list of author information is available at the end of the article
}

SpringerOpen

(c) The Author(s) 2021. This article is licensed under a Creative Commons Attribution 4.0 International License, which permits use, sharing, adaptation, distribution and reproduction in any medium or format, as long as you give appropriate credit to the original author(s) and the source, provide a link to the Creative Commons licence, and indicate if changes were made. The images or other third party material in this article are included in the article's Creative Commons licence, unless indicated otherwise in a credit line to the material. If material is not included in the article's Creative Commons licence and your intended use is not permitted by statutory regulation or exceeds the permitted use, you will need to obtain permission directly from the copyright holder. To view a copy of this licence, visit http://creativeco mmons.org/licenses/by/4.0/. 
Keywords: Endocrine disruptors, Retinoid signalling pathway, RAR, RXR, Neurological disorder, Learning impairment, Teratogenicity, Cyanobacteria, Hazard and risk assessment, Natural toxin

\section{Introduction}

Internationally, chemical substances are currently screened for endocrine activity in regulatory risk assessments (as for example in the European Union's Biocides regulation $[1,2]$ ), utilizing standard test methods that refer to chemical substances as endocrine active when interfering with sex hormone (oestrogen, androgen) receptors, steroidogenesis, or thyroid hormone signalling (EATS; the available tests are introduced in the "infobox" below) [3]. It is recognized that the endocrine system, however, is a complex interplay of different, often evolutionary highly conserved, mechanisms that by far exceed the above-mentioned four modes of action. It includes all hormone signalling pathways, interlinking and regulating an extensive set of functions, including development, growth, reproduction and metabolism [4-8], and this is being actively examined at inter-governmental levels [8-16]. The endocrine system is highly sensitive and circulating hormone levels are in the $\mathrm{pM}-\mu \mathrm{M}$ range, making it highly susceptible to interfering compounds [17, 18]. Interference of exogenous chemicals with the tightly regulated endocrine system may result in adverse health effects, that, especially when encountered during development, may have sustained and life-long [12 and references therein, 19] or even transgenerational impacts on individuals or contribute to non-communicable diseases like metabolic disorders and cancer [4, 18, 20-29].

To allow an assessment of risks related to chemicals in the environment, information on the ecological or human health hazard of these chemicals is needed $[2,3]$ together with information on exposure to these chemicals and/or mixtures, i.e. their levels and fate in the environment, to conclude as to whether there is a risk of adverse outcomes or not [30,31].

Despite the progress in the development of test methods screening for endocrine disrupting activity, endocrine pathways other than EATS remain under-investigated. Whilst currently there are no specific test methods available with respect to other endocrine mechanisms, these are being actively explored at the European level (https:// eurion-cluster.eu/), and internationally, for retinoids [13, reviewed in 14]. Such comprehensive reviews together with identification of relevant assays with reference and test chemicals are needed to address regulatory needs, prior to the development of the test method tools that can be included into legislative mechanisms.

In surface waters, endocrine disruption gained public attention when altered sex ratios, genital malformations, and reproductive impairment were discovered in aquatic vertebrates [6,33-38]. Most strikingly, feminization of male fish occurred at oestrogen levels below the limit of detection by analytical methods available at that time and also led to the collapse of a fish population in a Canadian experimental lake [39]. The oestrogen levels in the respective water bodies have been frequently attributed to poor treatment of communal wastewaters, containing high levels of human contraceptives [40]. More recently progesterone has been detected in UK shores in molluscs at concentrations equivalent to those used in contraceptives and hormone replacement therapy [41]. The striking impact of compounds interfering with the oestrogen hormone system has expanded the field of environmental endocrine disruption and enabled investigation of other endocrine pathways sensitive to environmental interference [42].

It is intended that this review provides a useful contribution to the discussion of under- and unregulated endocrine pathways, particularly in relation to the gap in hazard and risk assessment approaches to address anthropogenic and naturally occurring toxic retinoid substances for water quality. We focus on two key aspects of environmental chemicals' potential to interfere with retinoid signalling: (1) with respect to the presence of chemicals that elicit retinoid-like activity via retinoid receptors, and (2) the potential of the endogenous retinoid system to be a target for an expanded range of chemicals which could disrupt this system. In addition to retinoid signalling pathway-related developmental and reproductive endpoints [reviewed in 13, 14], here we facilitate the addition of the less well studied endpoints of cognitive function and neurological disease. We thereby intend to contribute to the evidence base needed for the development of the tools and approaches to address endocrine adverse outcomes related to disruption of retinoid signalling pathway. 


\begin{abstract}
Infobox: Available OECD standardized test methods for the hazard assessment of Endocrine Active Substances

OECD Guidance document 150 [3] provides detailed information and guidance on standardised test methods for Endocrine Active Substance (EAS) and endocrine disruptor (ED) testing, and the EFSA/ECHA have developed ED guidance for the use of these test methods in relation to current EU regulatory needs [2]. While EAS refers to the endocrine activity of the substance it does not necessarily result in an adverse health outcome. If the observed effect is irreversible then the substance is considered an ED with adverse health outcome $[3,43,44]$.
\end{abstract}

Oestrogen receptor (ER) binding can be measured using the ER binding assays in OECD Test Guideline 493 [45], and ER agonist and antagonist activity can be screened using in vitro reporter-gene assays [46]. In the OECD Endocrine Disrupter Conceptual Framework for testing, (anti) oestrogenic activity can be confirmed by the in vivo uterotrophic bioassay in rodents $[47,48]$.

In vitro and in vivo assays for the assessment of (anti) androgenic activity are also standardised and available [49-52]. The in vitro assay for androgen receptor (AR) activation [49] uses the same principle of reporter gene assays as the ERa assay. Although not adopted as a Test Guideline, the validated in vivo method to test for and/or confirm (anti) androgenic activity in aquatic animals is, for example, the androgenised female stickleback screen (AFSS [50, 53]), where a species-specific biomarker, spiggin, can be measured as an indicator of androgenic activity in the three-spine stickleback (Gasterosteus aculeatus) [54, 55]. For mammals, higher-tier testing for (anti)androgenic endocrine disruption relies on the Hershberger bioassay in rats, which is still used since its approval in the 1960s [51].

\section{Hazard characterization of retinoid substances - from molecular interactions to developmental and neurological outcomes in vivo}

Retinoid substances are chemically related to retinol (vitamin A). They are small organic molecules biosynthesized from isoprenoid precursors, mostly by photosynthetic organisms like phytoplankton and plants [69]. Retinoids, generally obtained from the diet [70-72], particularly retinoic acid, play a pivotal role during early development, driving anterior-posterior patterning in developing embryos and development of the vertebrate brain [73-77]. At the same time, retinoic acids are classified as teratogenic, due to the pronounced dependence on the spatio-temporal distribution of retinoids in the tissues of developing organisms [73, 78-81]. The
For both oestrogenic and androgenic activity, there are further whole animal (fish and amphibian) systems currently under validation, under the auspices of the OECD and specifically transgenic models are now on the OECD workplan that are intended to address the gap between in vitro and in vivo test methods. These include the "Rapid Estrogen ACTivity In Vivo" [56, REACTiV; 57, 58], the "Endocrine Active Substance, acting through estrogen receptors, using transgenic cyp19a1bGFP Zebrafish embrYos" [EASZY; 59] and the "Rapid Androgen Disruption Adverse outcome Reporter" [RADAR; 60, 61] assays. Whilst the in vitro ER test methods correlate well with in vivo models $[2,62]$, in vitro AR assay data do not correlate well with the Hershberger assay [63]. So in terms of refinement, it is expected that the RADAR assay will potentially be a great improvement on the Hershberger method.

Interference of chemicals with the steroidogenesis pathway, and therefore also with the biosynthesis of sex hormones, is covered by the Test Guideline 456 [64]. Similar to the ER and AR transactivation assays, this in vitro screening test provides mechanistic data on the potential of a substance to interfere with the production of corticosteroids and sex steroids, such as $17 \beta$-estradiol or testosterone.

In vitro screening tests for interference with the mammalian thyroid hormone system are currently under development [32] and those documented in the OECD thyroid scoping document [10] are being validated by EURL ECVAM $[65,66]$. For amphibians, eleutheroembryos of transgenic Xenopus laevis can be utilized to obtain qualitative information about interference with thyroid hormone signalling [67]. The recorded response is the expression of green fluorescent protein, that is governed by a thyroid hormone receptor sensitive promoter $[67,68]$.

developmental processes in which retinoids are involved are further discussed in "Phenotypic patterns of interference with retinoid signalling during development" section. Besides the tissue distribution and metabolization of retinoid isomers, also the expression pattern of retinoic acid receptor (RAR) and retinoid $X$ receptor (RXR) isoforms and variants in tissues determines retinoid effects $[78,82]$.

The endogenous ligand for RAR is all-trans retinoic acid (atRA; Fig. 1); for RXR it appears to be either 9,13-di-cis retinoic acid or 9-cis retinoic acid (9cRA; Fig. 1). Additional retinoids that have been shown to activate retinoid receptors include 9-cis didehydro retinoic acid, all-trans 5,6 epoxy retinoic acid, all-trans 4-oxo retinoic acid, and all-trans 4-oxo retinal [83-88]. In humans, 


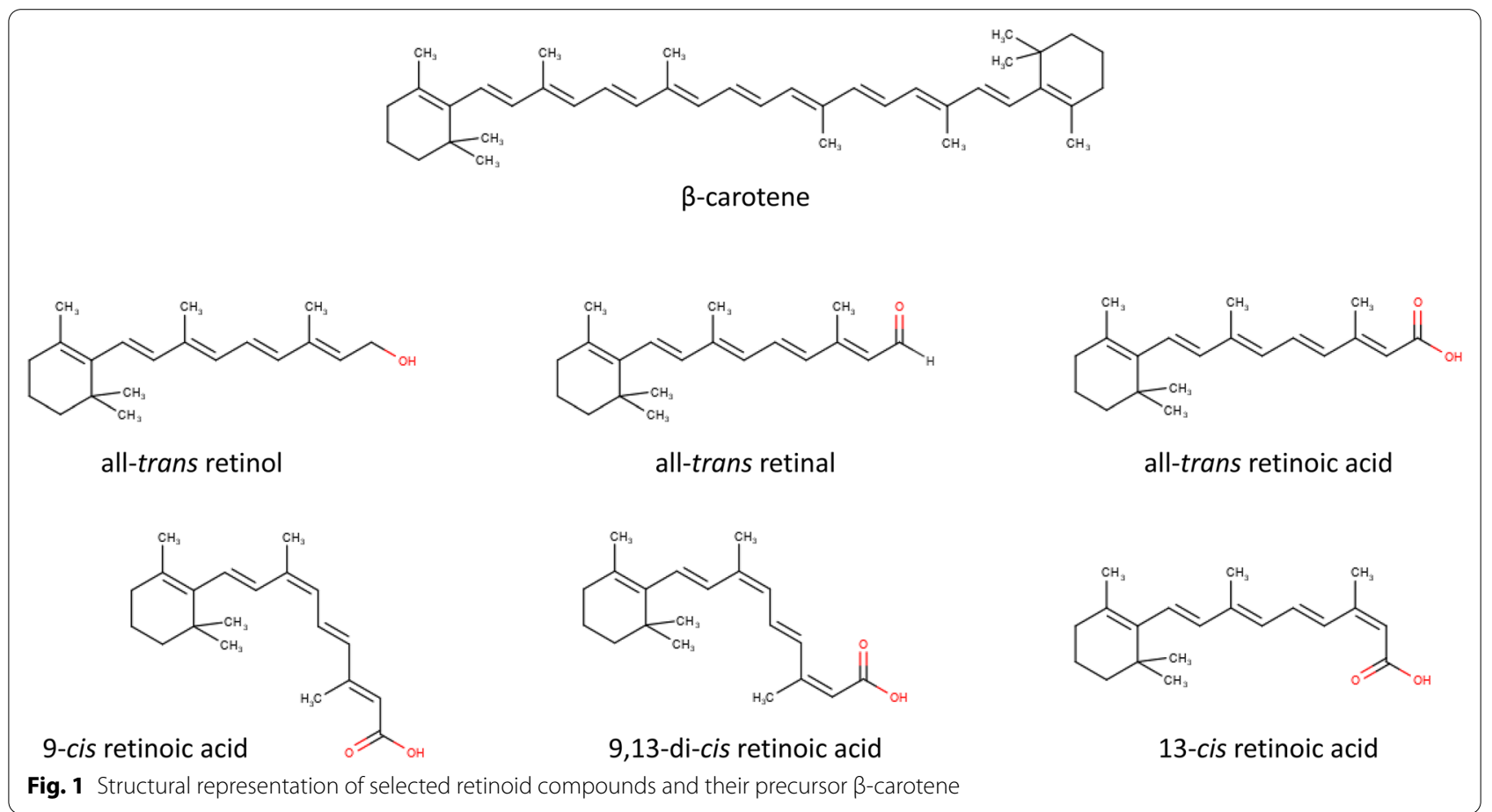

the biologically active and most potent atRA is obtained by sequential oxidation from all-trans retinol (vitamin A; Fig. 1) via alcohol dehydrogenases (esp. retinol dehydrogenase 10) [89] and retinal dehydrogenases (RALDHs, mainly RALDH2 in mammals) [90, 91]. Retinol is stored in the liver as retinyl esters [92-94]. atRA cannot be synthetized de novo in vertebrates and requires nutritional sources, which can be in the easily metabolized precursor forms such as $\beta$-carotene [80, 94-96]. The Population Reference Intake ranges between $250 \mu \mathrm{g}$ retinol equivalent/day in infants below the age of 1 year and up to $750 \mu \mathrm{g}$ retinol equivalent/day in children and adults [97] and is within the same range as the daily vitamin A intake recommended by Public Health England [72].

Binding of retinoids, primarily atRA, to RAR results in their heterodimerization with RXR and subsequent transcriptional activation of retinoic acid-responsive elements (RAREs), which govern a number of crucial cellular processes, including inflammation, proliferation, differentiation and carcinogenesis [28, 98, 99]. RARRXR heterodimers furthermore can recruit co-repressor complexes and, depending on the presence of natural or synthetic ligands, modulate or suppress gene expression [100-102].

While RARs show a higher specificity towards retinoid compounds binding and are the main driver in retinoid-mediated patterning and teratogenicity [e.g. recently reviewed by 103], the role of RXRs is broader.
One of the reasons is the molecular promiscuity of RXR. Type II nuclear receptors, characterized by forming heterodimers with RXR, govern the transcription of a large variety of target genes [104]. They are involved in the biological responses to many endogenous ligands, anthropogenic and natural chemicals and therapeutic drugs. The affected functions include lipid metabolism (peroxisome-proliferator activated receptor, PPAR), steroidogenesis, xenobiotic response (pregnane $\mathrm{X}$ receptor, PXR; constitutive androstane receptor, CAR), vitamin D receptor (VDR), liver functions (FXR, LXR), orphan nuclear receptors (Nurs), and thyroid hormone signalling (thyroid hormone receptor, TR [67]; Fig. 2) [7, 85, 88, 105-107]. Whilst the receptors TR, VDR, and RAR form non-permissive heterodimers, the others (Fig. 2) form permissive heterodimers with RXR, where the transcriptional activity is regulated by a ligand binding to one of the dimerization partners $[85,104,106]$. Dimerization is achieved via the asymmetrical so-called identity box - a small region within the ligand binding domain, which, in the case of RXR $\alpha$, consists of 40 amino acids $[108,109]$. This subdomain shows a very high degree of conservation. Especially, the two amino acids A416 and R421 have been shown crucial for dimerization of RXR $\alpha$ with RAR [108, 109]. The high conservation of the RXR identity box even across animal phyla underlines the evolutionary importance of RXR [110, 111]. 


\section{Non-permissive heterodimers}

Primary function: hormone receptors

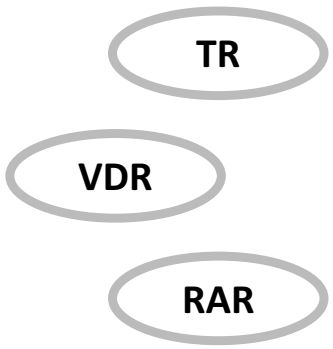

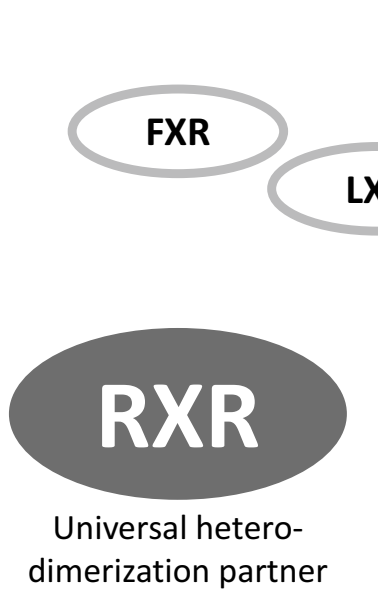

Nur77
Permissive heterodimers

Response to dietary substances (e.g. fatty acids, steroids), xenobiotics and pharmaceuticals

\section{LXR}

\section{PPAR}

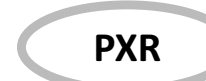

\section{CAR}

Nurr1

Fig. 2 Heterodimerization partners of the retinoid $\mathbf{X}$ receptor (RXR). Non-permissive heterodimers require ligand binding to the non-RXR monomer to elicit transcriptional activity, while monomers of the permissive heterodimers act in a cooperative synergistic fashion. This can greatly amplify the response to certain ligands in presence of synergistic RXR ligands and exaggerate the transcriptional response. CAR: constitutive androstane receptor, FXR: farnesoid X receptor, LXR: lipid X receptor, Nur77: nuclear receptor subfamily 4 variant 77, Nurr1: nuclear receptor related 1 protein, PPAR: peroxisome proliferator-activated receptor, PXR: pregnane X receptor, RAR: retinoic acid receptor, TR: thyroid hormone receptor, VDR: vitamin D receptor

\section{Molecular crosstalk in the RXR signalling pathway}

The fact that nuclear receptors share the common heterodimerization partner, RXR, indicates the potential for molecular crosstalk between signalling pathways dependent on RXR heterodimerization. The sequestration of ligand-bound RXR from the pool of active RXR monomers with downstream modulating activities is indicated [7], and also direct ligand activation of, e.g. the PPAR family by retinoic acids [112, 113] has been reported in addition to activation of retinoid receptors. Additionally, there is evidence of crosstalk to the thyroid hormone signalling pathway by heterodimers of TR with RXR in vitro [114] and augmentation of thyroid hormone-related effects by RXR activation in vivo [67]. Most often, the ubiquitous $\mathrm{RXR} \alpha$ isoform is involved in heterodimerization and it is essential for xenobiotic metabolism [7, 13, 115]. Competitive decrease of effect due to RXR $\alpha$ sequestration by retinoic acid/RAR has been reported for CAR [116], LXR, FXR, PPAR $\alpha$ [106], and PPARY [117] and may be implied in the metabolization and detoxification capacity mediated via activation of, e.g. PPARs. The capacity of RXRs to form heterodimers with several dimerization partners allows integration of signals from simultaneous and independent signalling pathways that can be further modulated by transcription co-factors [13, reviewed in 87]. The importance of allosteric modulators has been also stressed in a recent study on nuclear receptor binding to DNA target sequences (direct repeats and half-sites), where in vitro binding was predictive of in vivo binding, but not of in vivo function [104].

The importance of co-evolution of nuclear receptors and overlapping cis-regulatory elements also becomes apparent at the intersection of RAR/RXR and ER $\alpha$ signalling pathways. RAR/RXR signalling has been demonstrated several times to antagonize ER binding to respective DNA target sequences [118-121]. Besides the therapeutic use of this observation particularly in ERresponsive breast cancer [121], ERs play a critical role in organogenesis and maturation processes that, thus, can be affected by dietary and environmental factors.

Steroidogenesis critically influences the production and subsequently the circulating amount of the prototype sex steroids oestrogen and testosterone [13]. RAR/RXR play a pivotal role at the beginning of the steroidogenesis pathway, but RXR also as the essential dimerization partner for adjacent and subsequent steps interlinked with lipid metabolism (PPARs, LXR) and xenobiotic response (CAR, PXR) [13, 106]. At this interface, delivery of retinoic acid to the various nuclear receptors (RAR, PPAR or VDR) can have different consequences with respect to adiposity, such that, for example VDR activation in fibroblasts induces non-adipogenic gene transcription, whilst PPAR $\gamma /$ RXR heterodimers contribute to adipogenic processes $[7,122]$. 
Whilst the therapeutic potential of the interdependency amongst many pathways and retinoid signalling via RXR has already been discovered and drugs specific to RXR, so-called "rexinoids" (e.g. bexarotene) are available to treat certain types of cancers [123], the implications of unintentional deregulation of retinoid signalling remain to be elucidated.

\section{Phenotypic patterns of interference with retinoid signalling during development}

Interference with retinoic acid signalling has the highest impact on humans during development and was first observed in vitamin A (retinol) deficiency. This has been understood since the early twentieth century from studies that investigated the teratogenic effects of both excess and a lack of retinoid activity [124-130]. To date, vitamin A deficiency is still a concern, especially in developing countries where one-third (33.3\%) of pre-school age children and $15.3 \%$ of pregnant women have serum retinol levels below $0.7 \mu \mathrm{M}$ [131], resulting in severe risk of vitamin A-preventable blindness that has a fatality rate in children of 50\% within one year [131-133]. Without nutritional supplementation within the first year of life, this can be considered as irreversible retinoid disruption and interpreted as an example of an (irreversible) adverse outcome in humans justifying classification as an endocrine disruption pathway.

Retinoic acid gradients determine the dorso-ventral and anterior-posterior patterning of the embryo in the first trimester [73, 75, 78, 82]. Furthermore, the differential expression and activation of retinoid receptor variants and isoforms, together with the spatio-temporal regulation of RA synthesis and metabolism, drives organogenesis and elongation of the spinal axis [74, 76, 78, 134]. It also determines progenitor cells to the neural lineage, thus initiating the formation of the neural system including the spinal cord and the brain [73, 76, 82]. Notably, retinoid signalling drives the formation and segmentation of the hindbrain and neural network formation even before thyroid receptors are being expressed [73, 135, 136], and is involved in the correct development and positioning of other vital internal organs [137], including the heart [138-140], the lungs [139, 141-143], (male) genitals [13, 144-147], and the kidney [148, 149]. Overall, RA governs a multitude of developmental effects and also influences processes in adults, namely neuronal plasticity in the brain [150-153], peripheral neural regeneration [154-156], immune function [157-159], epithelial function $[139,160]$, and reproduction [13]. An overview on the processes sensitive to or dependent on retinoic signalling is outlined in Table 1 .

The most critical elements for interference in the retinoid signalling pathways, beyond RARs and RXRs, are the metabolizing enzymes of the cytochrome P450 subfamily 26 (CYP26) CYP26A1, CYP26B1, and CYP26C1 [94, 161, 162], the retinol-converting alcohol dehydrogenase $(\mathrm{ADH})$, and retinal-oxidizing dehydrogenases (RALDHs) [90, 94, 163, 164]. Efforts to identify key players and switches in the hierarchical signalling network and sort them into adverse outcome pathways (AOPs) continue to be undertaken with respect to vertebrate axial and neural tube development $[14,165,166]$, as well as mammalian reproduction [reviewed in 13].

Besides retinoids themselves, other environmental contaminants, such as pharmaceuticals (e.g. valproic acid), flame retardants (e.g. polybrominated diphenyl ethers), plasticizers (phthalate esters), and pesticides (triazole fungicides) have been reported to alter retinoid signalling biomarkers and induce retinoid-like teratogenic effects [111, 167-170] (see also Table 1). Exposure assessment of pharmaceuticals with the retinoid mode of action may require different regulatory approaches, depending upon the route of exposure, i.e. whether there is oral intake/ dermal application, as opposed to their occurrence and potency in (waste)waters.

\section{Contribution of retinoids to chronic neurological disorders}

The contribution of endocrine disruptors to neurological disorders is receiving more attention, and increasing resources are being put into funding such research [e.g. $32,171]$. In addition to known adverse teratogenic effects during development, particularly, brain and neurodegenerative conditions such as Alzheimer's and Parkinson's disease, or depression may be linked to altered retinoid signalling $[172,173]$.

While retinoid compounds are well described as early morphogens of the central nervous system (CNS) during development, their role in postnatal development of the brain is less investigated. Retinoid signalling is implied in neural plasticity, required for the formation of new memories and for learning [151, 174-176], in affective disorders [177], and in ageing - namely in Alzheimer's disease and dementia [178].

To date, neurodegenerative diseases such as dementia, Parkinson's, Alzheimer's, and Huntington's disease, are the $6^{\text {th }}$ leading cause of deaths in adults in the US $[179,180]$. Unlike mortality due to heart disease, stroke, or HIV, deaths linked to Alzheimer's disease have more than doubled between 2000 and 2018 [179]. Even more severe is the situation regarding neurological disorders in general, which are the second leading cause of death after heart disease and the leading cause of disability worldwide $[181,182]$. To date, there is no cure for dementia and treatment focuses on ameliorating the symptoms of 


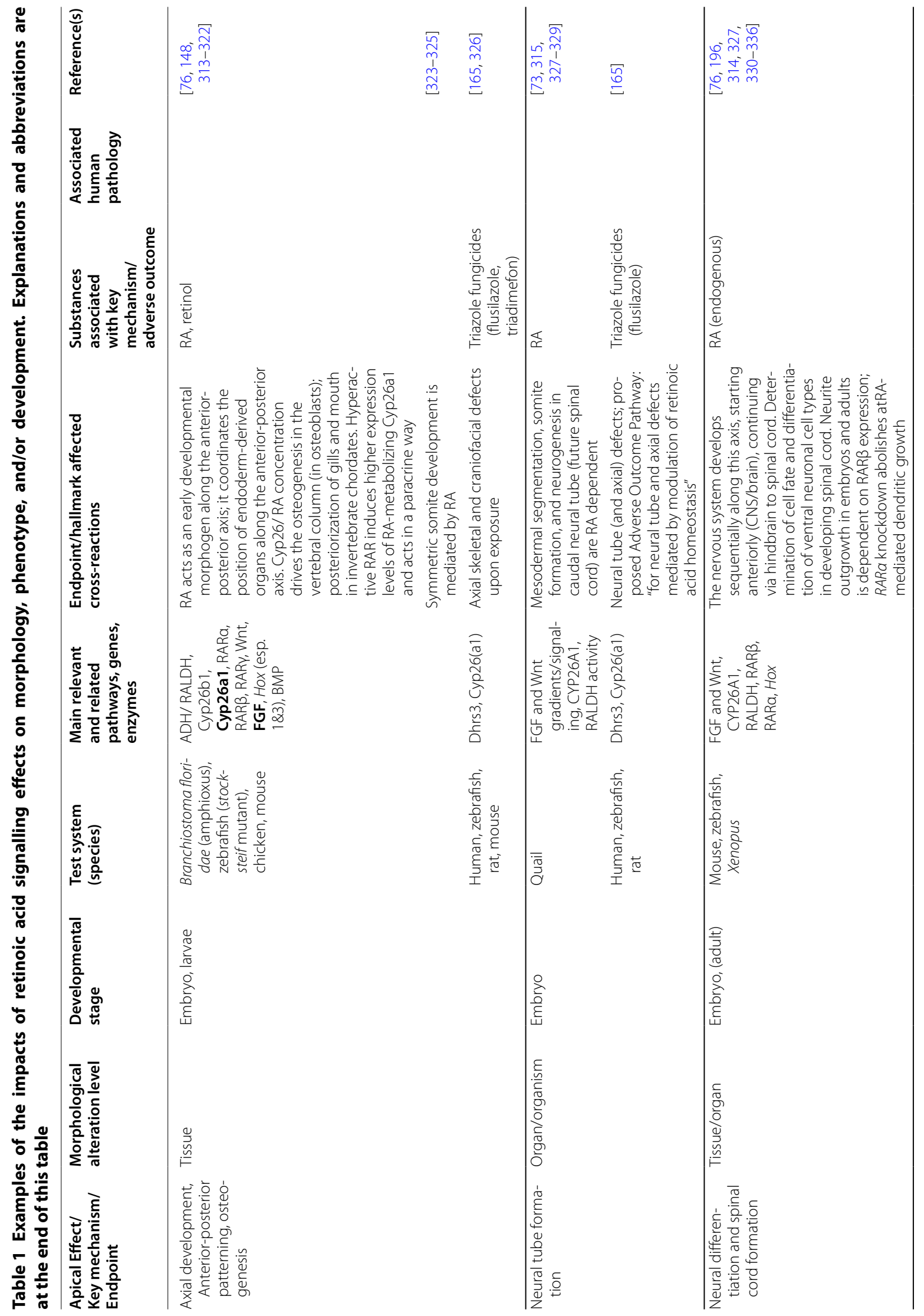




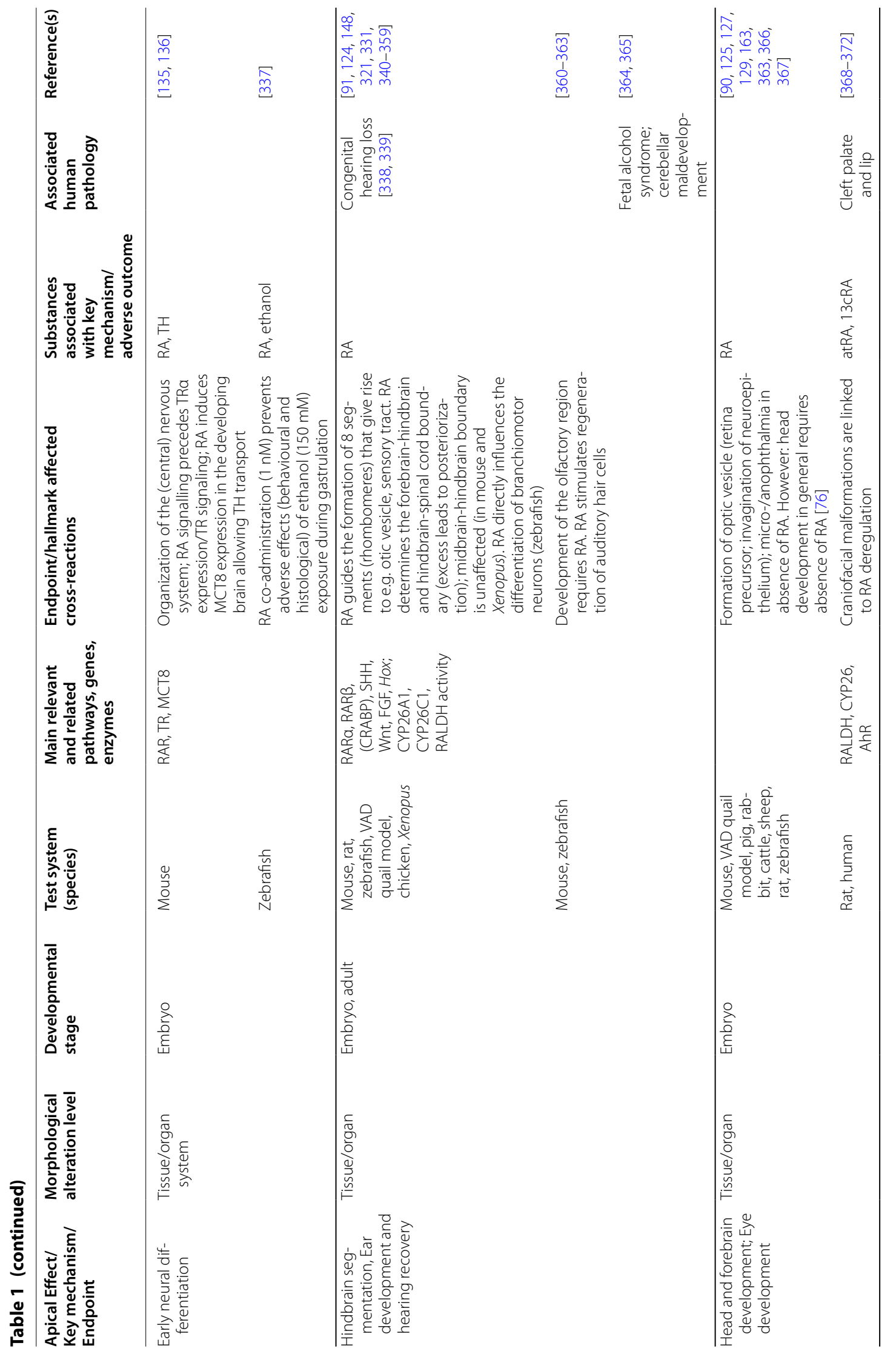




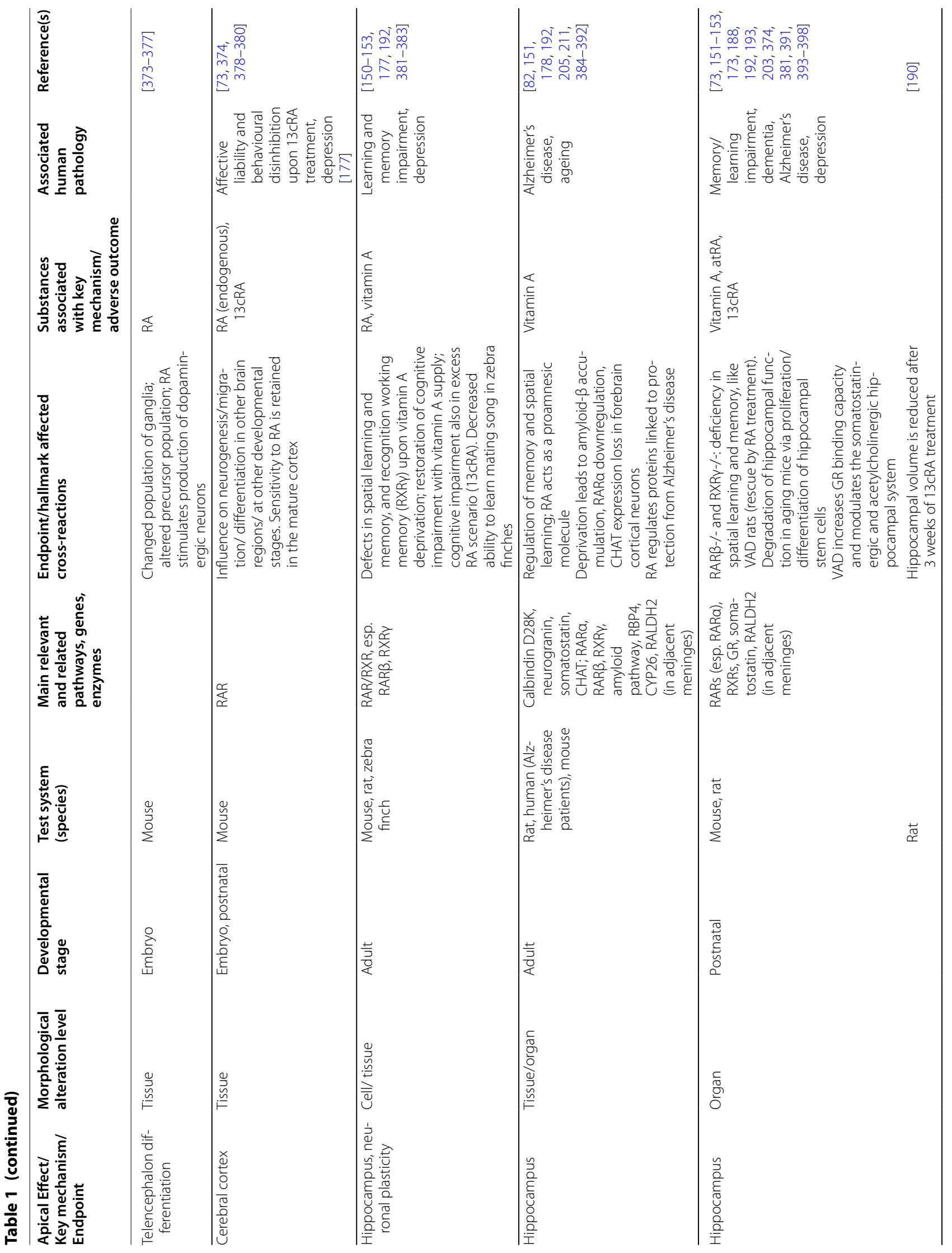




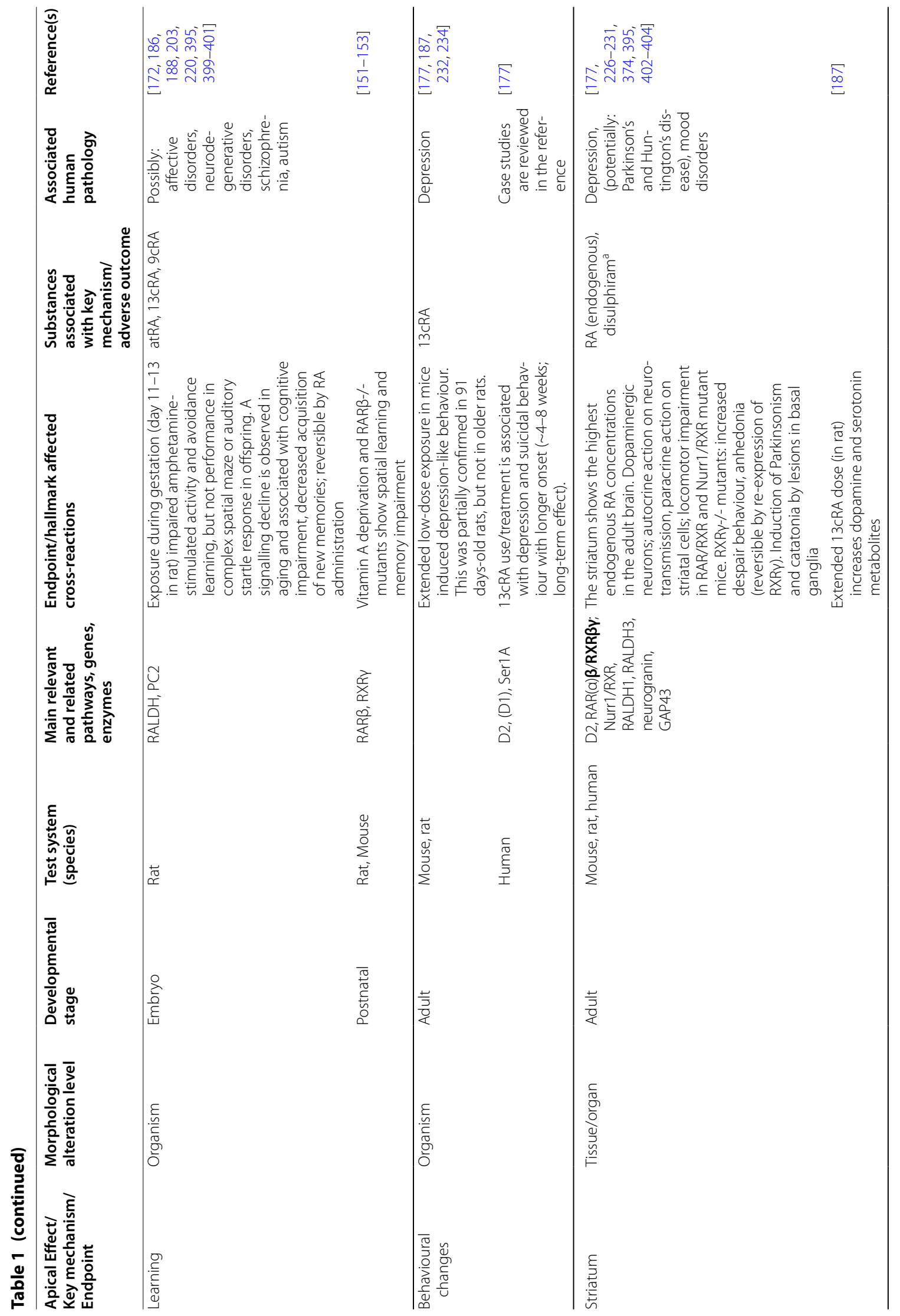




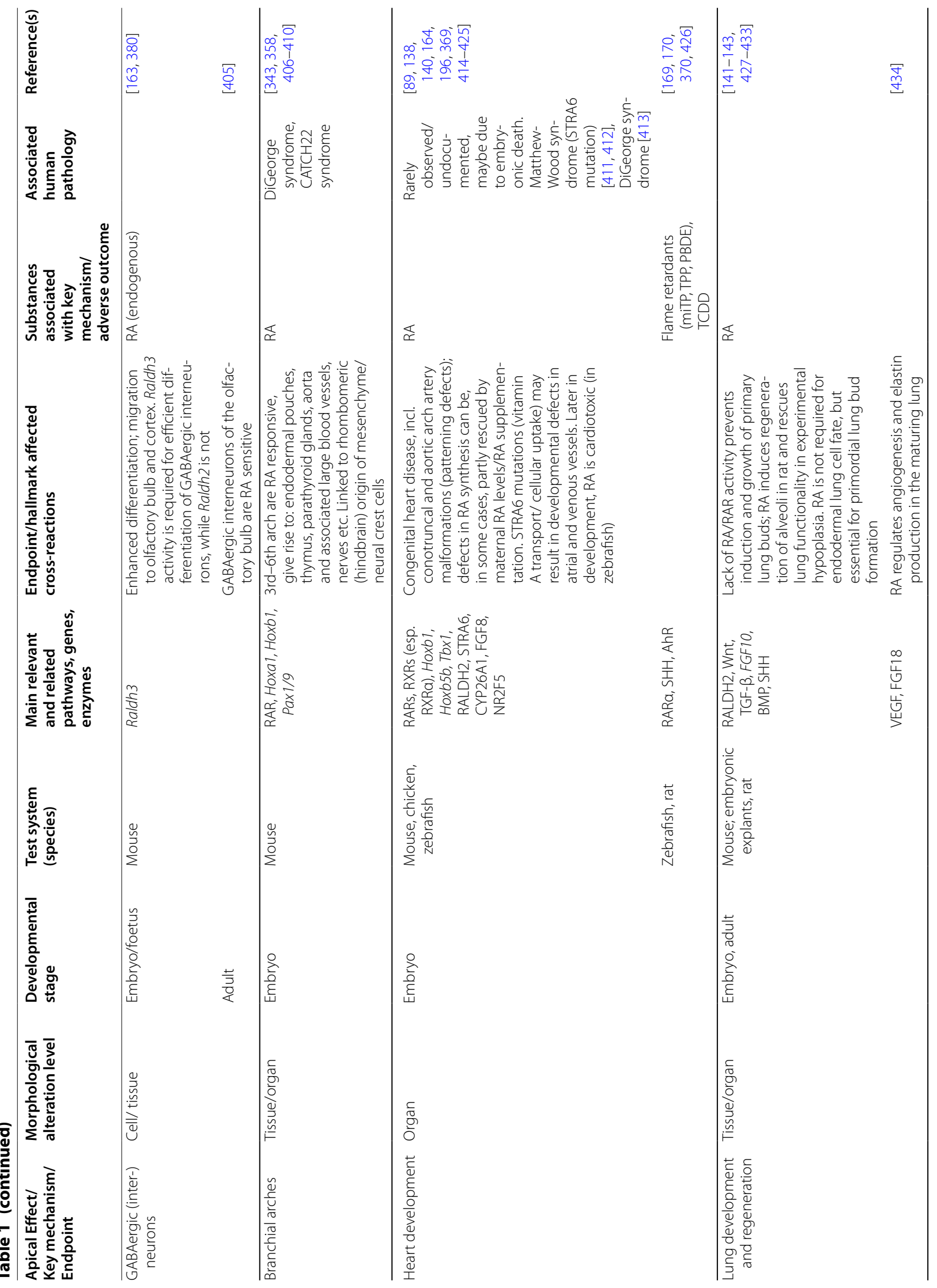




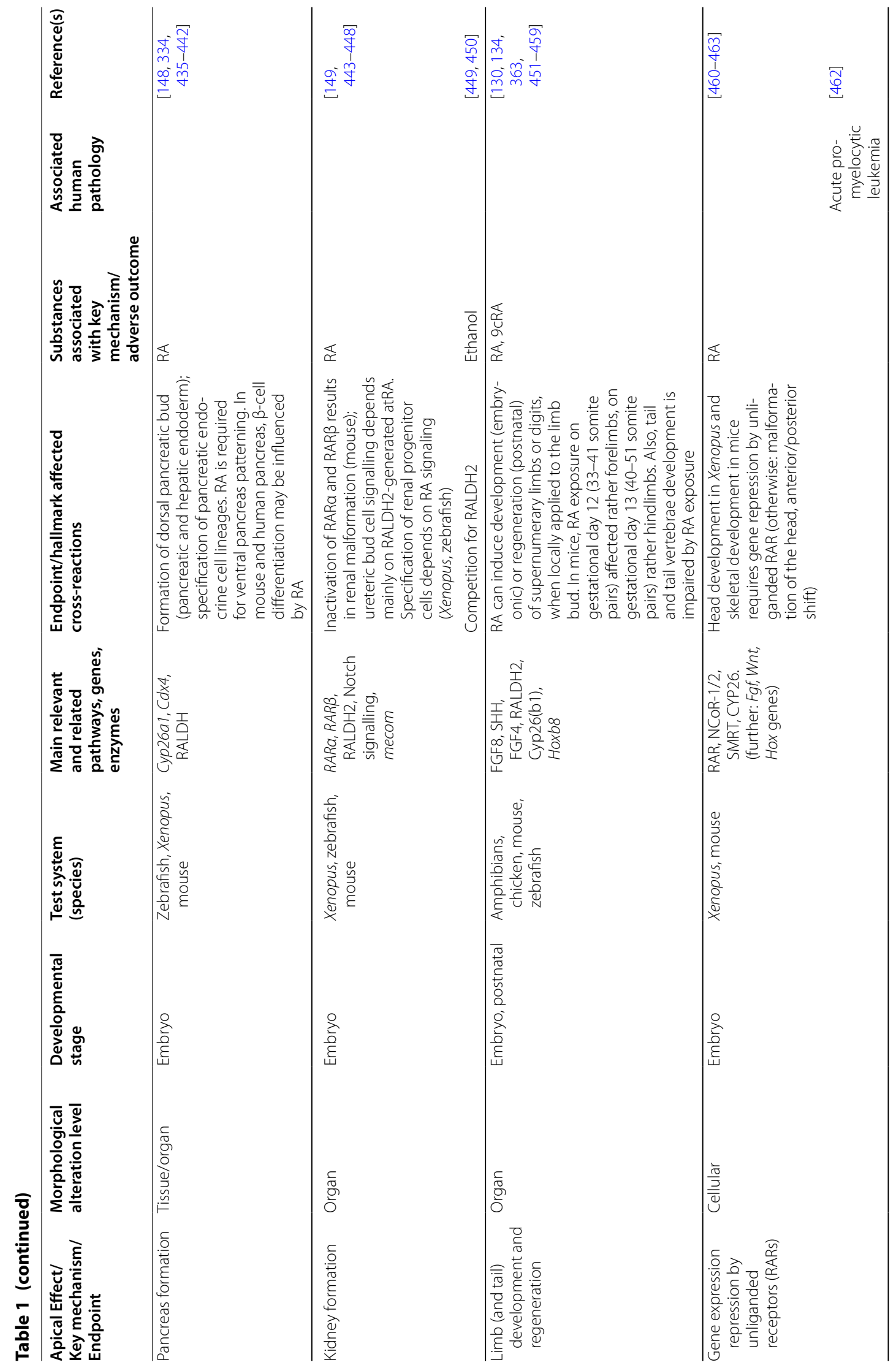




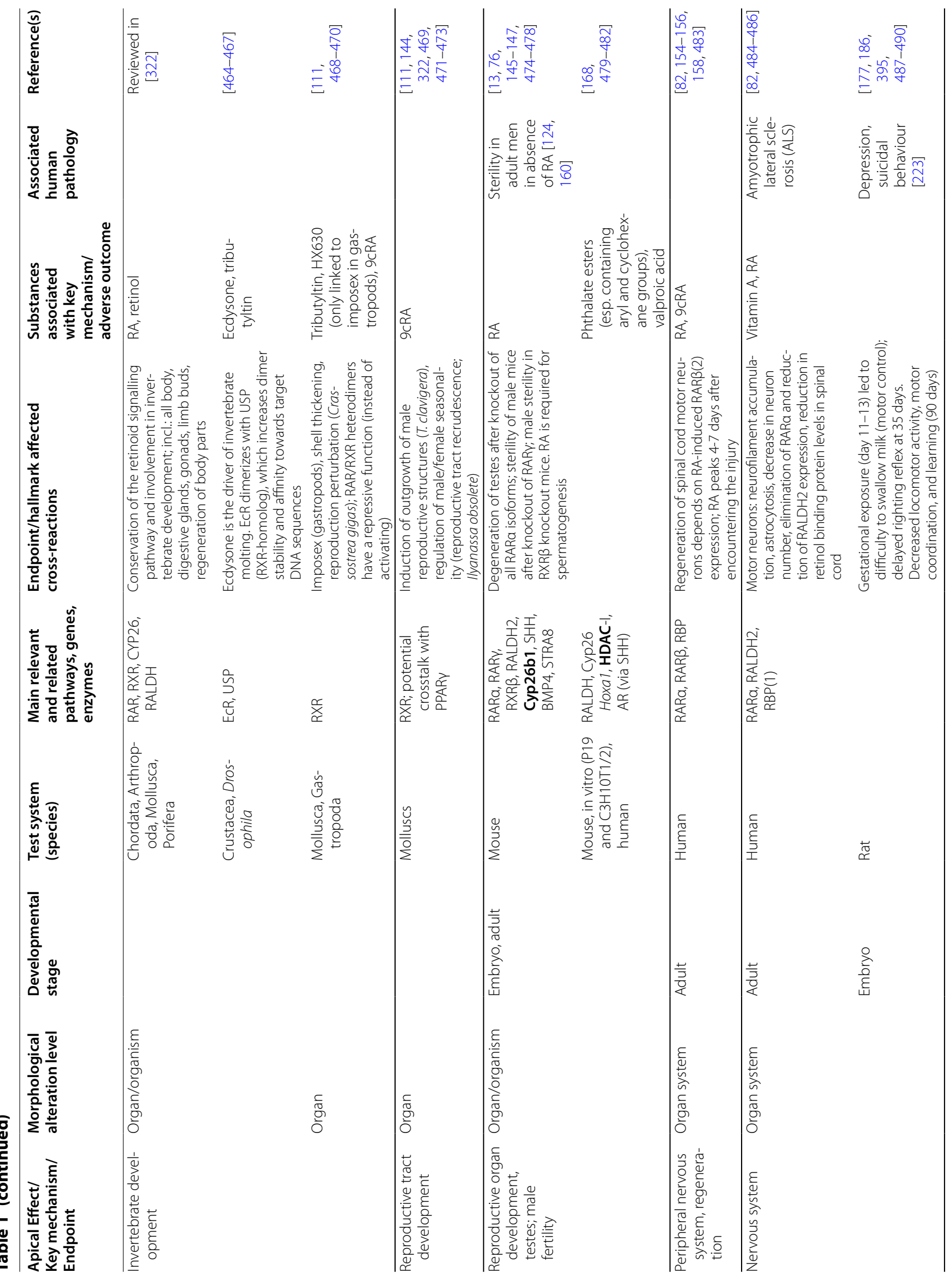




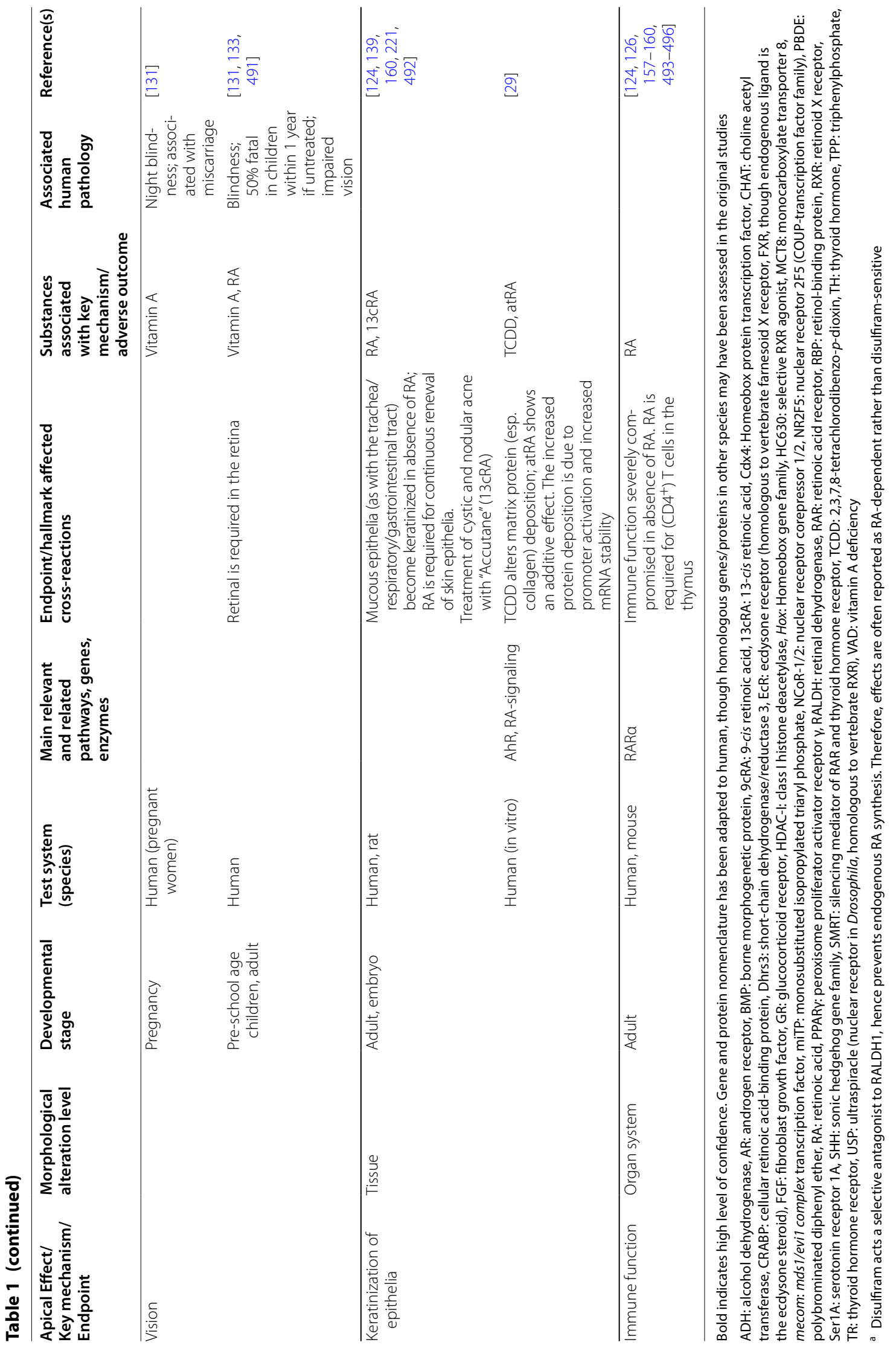


cognitive decline and increasing or maintaining quality of life [179].

While risk factors associated with dementia are mostly age, genetic predisposition (family history of dementia), or life-style related (high BMI, non-healthy diet, lack of physical and cognitive exercise) $[179,182]$, the contribution of environmental exposure has also been considered [183-185].

Most observations regarding retinoid signalling and adverse health outcomes in adolescents and adults have been derived from human intervention and clinical studies together with animal in vivo modelling. Of particular relevance are studies with pharmacological application of $13 \mathrm{cRA}$ for the treatment of acne or cancer [177, 186, 187].

Retinoic acid signalling is necessary for the differentiation and speciation of cell types, particularly in neurons [82]. While the differentiation of neurons is often perceived as restricted to early developmental stages, in fact many postnatal processes, including memory and learning, are dependent on neural differentiation and speciation (also known as neural plasticity) throughout life [174, 188-190].

\section{Cognitive function, memory, learning, and dementia}

Postnatal disturbance of RAR/RXR signalling impairs cognitive functions, especially in the forebrain and hippocampus [191]. Indeed the hippocampus region retains high postnatal RAR expression, and so is most susceptible to RA signalling interference [192-194]. One potential role of RA signalling in the adult brain is the modulation of synaptic plasticity, that is required for learning and the formation of memories [173, 174, 188]. In a mouse model, functional expression of retinoid receptors has been shown to be critical for long-term potentiation (RAR $\beta$ ) and long-term depression (RAR $\beta$ and RXR $\gamma$ ) [151]. The same study linked the decreased synaptic plasticity with a substantial performance loss in spatial learning and memory tasks in mice. While Chiang et al. [151] did not study the role of RAR $\alpha$, Aoto et al. [195] observed a rapid increase in synaptic strength upon treatment of primary rat neurons in vitro with $1 \mu \mathrm{M}$ atRA or increased endogenous atRA synthesis due to decreased neuronal activity. The homeostatic modulation of synaptic strength was mediated by atRA via dendritic, i.e. non-nuclear, RAR $\alpha$ and upregulated postsynaptic glutamate receptor 1 (GluR1) expression in a transcriptionindependent fashion [195]. Membrane-bound RAR $\alpha$ was also shown to be involved in the differentiation of spine neurons from the hippocampus [196], suggesting a nontranscriptional role of RARs and perhaps of RA as a paracrine signalling molecule.
Interestingly, the involvement of RA signalling in learning processes in vertebrates is not limited to mammals and may even play a role in invertebrate learning [197]. It has been shown that RA is critical for learning and song maturation in songbirds (zebra finches) [198, 199]. Unlike vocalization in mice, song maturation involves a learning aspect similar to that in human speech [200]. Convergent signalling mechanisms of forkhead box protein P2 and RA have been hypothesized to play a role in learned vocalization in both, birds and humans [200].

Involvement of RA signalling in these key cognitive functions raises the questions of its role in neurodegenerative diseases. Age-related cognitive decline with impaired spatial learning and memory is associated with decreased RA signalling in elderly vertebrates (human and mice) $[201,202]$. In elderly mice with impaired cognitive function, the administration of 13cRA re-established RA signalling and hippocampal RAR $\beta$ and RXR $\beta / \gamma$ expression and rescued the cognitive impairment [153, 201, 203].

\section{Therapeutic applications}

As a specific form of dementia, Alzheimer's disease (AD) is characterized by formation of amyloid- $\beta$ plaques in the CNS, which leads to inflammation and subsequent neurodegeneration $[179,204]$. Due to a reported decrease in RA signalling in AD patients' brains, particularly in the hippocampus region responsible for the formation of memories [201, 202], retinoids, especially 13cRA, are proposed for AD treatment as neuroprotectants [123, 205-209]. Furthermore, specific synthetic agonists of $\mathrm{RAR} \alpha / \beta$, such as tamibarotene, that are in use for cancer treatment, have been explored for AD treatment [209], but the clinical trials seem not to have progressed since [210]. For $A D$, disruption of RA signalling was linked to increased amyloid- $\beta$ deposition in rats [211], and RAR-agonism was effective to act both preventively and therapeutically to decrease amyloid- $\beta$-induced damage to human cell cultures in vitro and to mice in vivo [212-218]. Besides RARs, also RXRs are being explored for their pharmacological potential in neurodegenerative and inflammatory disease treatment, though the results are not conclusive so far $[123,219]$.

In contrast to the recovery of learning and memory abilities in elderly mice, longer-term (6 week) administration of $13 \mathrm{cRA}$ at a therapeutic dose $(1 \mathrm{mg} / \mathrm{kg} / \mathrm{day}$, i.p.) during young adulthood decreased cell proliferation in the murine hippocampus and was associated with impaired learning and memory formation [192]. The authors consider this result to be due to an insufficient growth factor supply to maintain a large differentiating neuron population, leading to premature neuronal death and longer-term decreased performance in RA-sensitive 
tasks. However, the impaired cognitive functions could also be linked to affective depression disorders, as reported in humans after extended periods of RA treatment [177].

Affective disorders - altered mood, depression, and suicide RA was first linked to altered behaviour in rats in 1986 [220]. Later a link between affective disorders and RA in humans was proposed after 13cRA was approved for medical use as a treatment of severe cystic and recalcitrant acne in 1982, leading to the inclusion of a warning on the label [221, 222]. A systematic review conducted by Marqueling and Zane [223] and an almost parallel review of studies by Strahan and Raimer [224] concluded that the current data available neither confirm nor disprove the association. The latter however noted that changes in mood can be accounted to 13cRA [224]. Further case studies and reports on the involvement of retinoid exposure in affective disorders have been summarized by Bremner et al. [225].

Here, we briefly introduce mechanistic data generated from animal models, with respect to the involvement of RA signalling in the dopaminergic system, as this is of particular interest with respect to the development and manifestation of affective disorders, as well as schizophrenia.

In the late 1990s, mutation and knockout of RAR $\beta$, $\operatorname{RXR} \beta$, and RXR $\gamma$ in mice were observed to be linked to impaired locomotion and decreased signalling via dopamine receptors 1 and 2 (D1R and D2R) [226, 227]. Also, the involvement of the orphan nuclear retinoid receptor 1 (Nurr1) in the differentiation and/ or maturation of dopaminergic neurons was hypothesized [226, 228]. Consecutively, the involvement of RA signalling in the development of the dopaminergic system, particularly in the expression of D2R, was confirmed in mice [229] and rats [227, 230, 231]. Of interest are also studies of chronic 13cRA administration in mice that better reflect an extended exposure to retinoids. Administration of therapeutic doses $(1 \mathrm{mg} / \mathrm{kg} /$ day) to young adult mice over 6 weeks did not alter general locomotor activity, but increased depression-like behaviour in the forced swim test and tail suspension test [232]. A follow-up literature review to this study proposed alterations to the serotonin neurotransmitter system rather than dopamine [233]. This is in line with an extended 13cRA exposure study in rats, which affected the serotonin rather than the dopamine neurotransmitter system [187]. Interestingly, a parallel study with chronic exposure to 13cRA or atRA in rats did not confirm the observed behavioural despair (forced swim test) observed by O'Reilly et al. [232], indicating species differences in sensitivity to RA [234].

Another parallel between depression in (elderly) human and in mice was drawn rather recently, when Qi et al. [235] observed post-mortem a decrease in mRNA levels of brain-derived neurotropic factor (BDNF) and RA signalling pathway elements in the brain of depressed patients and were able to confirm this observation in mice (BDNF is a biomarker also considered for inclusion in AOPs for developmental neurotoxicity and learning impairment [236-238]). Additionally, they identified a RA-responsive element in the tropomyosin receptor kinase $\mathrm{B}$ (TrkB; receptor for BDNF) promoter region specifically targeted by RAR $\alpha$ and thereby confirmed crosstalk between the RA and BDNF signalling pathways [235].

\section{Schizophrenia}

While the multifactorial aetiology of schizophrenia includes genetic and environmental risk factors, critical areas are early neurodevelopment, social behaviour and cognitive ability [239, 240]. In fact, genetic predisposition by itself is not necessary nor sufficient for the development of schizophrenia and the developmental cascade leading to the disease should include interactions with the environment [241]. Whilst no discrete substance has been proven to cause schizophrenia, it has been hypothesized that the neurochemical processes affected by some recreational drugs play a role in the development of schizophrenia and psychoses [summarized in 241]. These processes are signal transduction via dopaminergic [242] and glutamergic synapses [243], the endocannabinoid system [244], and (neuro-)inflammation [245].

Twenty years ago retinoid signalling was postulated to be involved in the development of schizophrenia [246], and whilst further mechanistic evidence is present, it is not sufficient for confirmation. The link has been established based on a predisposition for schizophrenia in children with congenital anomalies similar to RA signalling disturbance, convergent gene loci of schizophrenia risk factors and the RA signalling cascade (esp. CYP26B1) [240, 247], and the already mentioned sensitivity of the dopamine neurotransmitter system, particularly D2R, to RA interference (see "Affective disorders - altered mood, depression, and suicide" section) [outlined in 246]. Besides the dopamine system, also $\gamma$-amino butyric acid (GABA)-ergic interneurons in the prefrontal cortex, whose aberrant development is associated with neurological disorders including schizophrenia, have been shown to be sensitive to RA [248].

Although a considerable number of studies address the biologically plausible link between retinoid signalling and 
neurological diseases, on balance, the evidence supporting the link is currently insufficient to attribute causation (see Table 2).

Whilst the causal link between aberrant retinoid signalling and neurological disease is currently weak, the biological plausibility of the association is high: RA is a morphogen during early development and is strongly involved in shaping the CNS, including differentiation and maturation of neurons. Despite the significant role during development, the role of RA signalling in the adult or postnatal brain is less clear. Still, the conserved mechanisms of RA signalling are most likely to act also in the adult brain, though the effects may be less evident due to the multitude of parallel processes and potential influencing factors. Also, it is difficult to simulate and assess the many hues of neurological disease in animal models that are distinctly different from humans and it is not possible to assess behavioural changes in in vitro systems.

The "Cognitive function, memory, learning, and dementia"-"Schizophrenia" sections introduced several neurological conditions that share common affected personality traits due to changed connections in the CNS and altered neural plasticity. While modified RA signalling is not the single cause of adverse psychological and neurological outcomes, it is a strong candidate for connecting environmental exposure to neurological and/or neurodegenerative disease by modulating neurotransmitter systems (i.e. the dopaminergic system) and altering the base-line population of (non-) differentiated cells in the CNS. The role of the retinoid signalling pathways is especially pronounced, because interference of environmental chemicals does not have to be mediated via the molecular initiating events of the nuclear receptors (RARs and RXRs) directly, but could interfere with the endogenous retinoid homeostasis, e.g. by altering RA degradation (via CYP26 enzymes) or its biosynthesis (via ALDH and/or RALDH).

\section{Sources of retinoids in surface water - exposure}

Whilst retinoids are an intrinsic part of the diet for terrestrial animals and humans, aquatic animals in particular may be susceptible to involuntary exposure to excess retinoids at critically sensitive early-life stages [79] due to the prevalence of retinoid sources, both natural - cyanobacteria (blue-green algae) in eutrophic (fresh)water ecosystems [249-252] - and/or anthropogenic - wastewater discharge [253].

Retinoid-like activities in environmental matrices mediated via RAR or RXR can be measured by in vitro receptor transactivation assays, similar to ER and AR (see "Infobox"). In fact, ligand binding to specific nuclear receptors that leads to the transcription of target genes which, in the case of reporter assays, govern the expression of an easily detectable (e.g. luciferase) product, has become the method-of-choice for recent screening programmes targeted at uncovering endocrine activities of chemicals in a high-throughput manner [254-256]. The signal reflecting the extent of receptor transactivation can be quantified relative to the reference ligand (atRA for RAR, 9cRA for RXR) [257-259]. Detected retinoid-like activity for the different types of samples is expressed as equivalent concentration of the reference ligand that would cause the same response. These retinoic acid equivalent concentrations integrate the potential of a given mixture to activate the transcriptional response of the receptor and are more informative than targeted analyses for a limited set of compounds.

\section{Cyanobacteria}

An important source of retinoids to surface waters is cyanobacterial blooms in eutrophic freshwater ecosystems. Anthropogenic eutrophication of water bodies is driven by agricultural activities and insufficient removal of nutrients (mainly nitrogen and phosphorous) from communal wastewaters $[260,261]$. The ability of cyanobacteria to fix dissolved carbon dioxide $\left(\mathrm{HCO}_{3}{ }^{-}\right)$by photosynthesis makes their occurrence independent of bioavailable carbon [262]. Together with global climate change, these are the biggest factors enhancing cyanobacterial blooms in (fresh-)water environments [260, 263]. As a result, the main limiting nutrients are bioavailable inorganic nitrogen (nitrate, $\mathrm{NO}_{3}{ }^{-}$) and phosphorous (phosphate, $\mathrm{PO}_{4}{ }^{3-}$ ) [261]. These nutrients are further concentrated in long, dry warm periods in summer, that are increasing with, and exacerbated by, global climate change. Evaporation and increased abstraction from surface water bodies leads to increasing water temperatures especially in shallow surface waters, further fuelling the development of cyanobacterial blooms [264266]. Greater abstraction will also be expected with the growth in human population. In addition, climate change increases the frequency and size of flooding events which, in turn, (a) increase sediment loss to surface water (which is a key mechanism via which phosphorus enters water [267]) and (b) promote resuspension of nutrientladen benthic sediment, both of which further exacerbate cyanobacterial blooms [268]. Besides being an integral part of the aquatic ecosystem, cyanobacteria produce a large variety of secondary metabolites, many of which show bioactive or even toxic properties [269, reviewed in 270]. Amongst others, cyanobacterial bloom biomass and affected waters were shown to contain retinoids, elicit retinoid-like activity in vitro, and to cause in vivo 
teratogenic effects in Xenopus laevis tadpoles and Danio rerio embryos, which implies relevance towards wildlife populations [79, 249, 251, 252, 271-275]. Although algae contain retinoids at comparable levels in their biomass to cyanobacteria [251, 271, 274], it is the latter that are major contributors to retinoids in surface waters due to their proliferation. While the occurrence of cyanobacteria themselves is natural, their hazardous massive blooming events are strongly driven by human actions making it an "anthropo-natural" phenomenon.

\section{European and Asian environmental case examples}

The chemical assessment of environmentally occurring retinoids or a quantification of retinoid-like activity is a monitoring data gap. However, the few studies systematically analysing water samples reveal highly concerning levels of retinoids or their activity.

Measured in Czech lake waters, retinoid-like activities reached up to $263 \mathrm{ng}$ atRA equivalent $(\mathrm{REQ}) \times \mathrm{L}^{-1}$ [249]. While this concentration does not exceed the nominal EC20 of atRA in zebrafish embryos, total bloom biomass extracts did cause teratogenic effects at these concentrations [272]. This indicates that environmental retinoids extend beyond atRA and 9cRA. Indeed, a broad spectrum of retinoids has been detected in field samples of cyanobacterial blooms and their surrounding water, as well as in laboratory cultures and their exudates [84, 249, 251-253, 271, 275, 276]. Among the retinoids detected are retinoic acids (atRA, 9cRA, 11cRA, 13cRA), RA derivatives (5,6-epoxy atRA, 7-hydroxy atRA, 4-oxo atRA, 4-oxo 9cRA, 4-oxo 13cRA), retinal and its derivatives (all-trans retinal, all-trans 4-oxo retinal) [249, 251253, 271, 272, 276]. However, the chemical analysis of retinoids could not entirely explain the retinoid-like bioactivity observed in the biological assays, hence it underestimates the endocrine active potential arising from these waters.

Besides occurring in cyanobacterial blooms, retinoids also enter the environment via wastewater effluents [reviewed in 253]. Humans, as well as animals, excrete retinoids most often as 4-oxo derivatives [277-279]. Even though retinoids are sensitive to oxidation and isomerization processes that significantly alter their bioactivity, in municipal wastewater treatment plants the treatment efficiency may not be sufficient for their complete removal and, consequently, retinoids can be released to the receiving water bodies at concentrations of up to $11.5 \mathrm{ng} \mathrm{REQ} \times \mathrm{L}^{-1}$ [253, 271, 280-283]. Amongst the detected isomers, oxidized (i.e. 4-oxo-) derivatives of retinoic acids dominate over the parent compounds. Besides dietary excreted retinoids, pharmaceutical retinoids (tretinoin (atRA), alitretinoin (9cRA), isotretinoin
(13cRA), bexarotene, and others; pharmaceutical use: cancer, acne $(\geq 0.5 \mathrm{mg}$ isotretinoin $/ \mathrm{kg} /$ days $)$, eczema treatment $[222,284,285])$ and cosmetically used retinoids (retinol, retinyl palmitate, retinyl acetate; cosmetic use: body lotion ( $\leq 0.05 \%$ retinol equivalent), hand/face cream or rinse-off products $(\leq 0.3 \%$ retinol equivalent) $[279,286])$ can be excreted into wastewaters or washedoff after topical application. The use of retinoic acid in cosmetics is restricted within the EU and Norway [70, 286, 287], recommendations are provided by the European Medical Agency, with respect to oral use of the retinoid containing medicinal products in pregnancy, and also for those suffering from neuropsychiatric disorders [222]. The potential contribution routes to retinoid compounds in surface waters are also summarized in Fig. 3.

\section{Anthropogenic and natural endocrine-active substances}

The presence of unregulated endocrine-active substances (EAS), like retinoids, in waters raises the questions: to what extent do they contribute to mixture effects? Do we need to update the assessment of water safety for human consumption? To date, EAS in the environment are managed by regulating their commercial release: the manufacturer is responsible for correct labelling of the product and has to assure an acceptable risk of the active ingredient, or the preparation, to the environment. While this management scheme covers anthropogenic releases of chemicals, it cannot capture natural sources that contribute to the cumulative effects observed in the environment in situ. Hence, it does not reflect the need to tackle mixture effects in the environment directly or just before release of complex mixtures like waste water effluents into the environment [288-291].

The European Union's visionary concept of water legislation, encompassed in the Water Framework Directive (WFD, [291]), the Urban Waste Water Treatment Directive [288, 292], the Nitrates Directive [293], and the Drinking Water Directive [DWD, 294], aims to secure safe drinking water now and for future generations. However, the demand for water, for nutritional, recreational and agricultural purposes, increasingly challenges water supply managers and may require switching to lessfavourable water sources to provide the consumers with the desired supply [295, 296].

To meet the high expectations for surface and drinking water safety, a holistic assessment at the point of abstraction for drinking water, including sub-acute and/ or longer-term effects of EAS and putative endocrine disruptors, rather than managing only anthropogenic inputs of active substances (e.g. pesticides, fertilizers, pharmaceuticals) to the environment would be beneficial for risk assessment and more reflective of the true burden of EAS exposure via drinking water [44, 290, 297, 298]. 


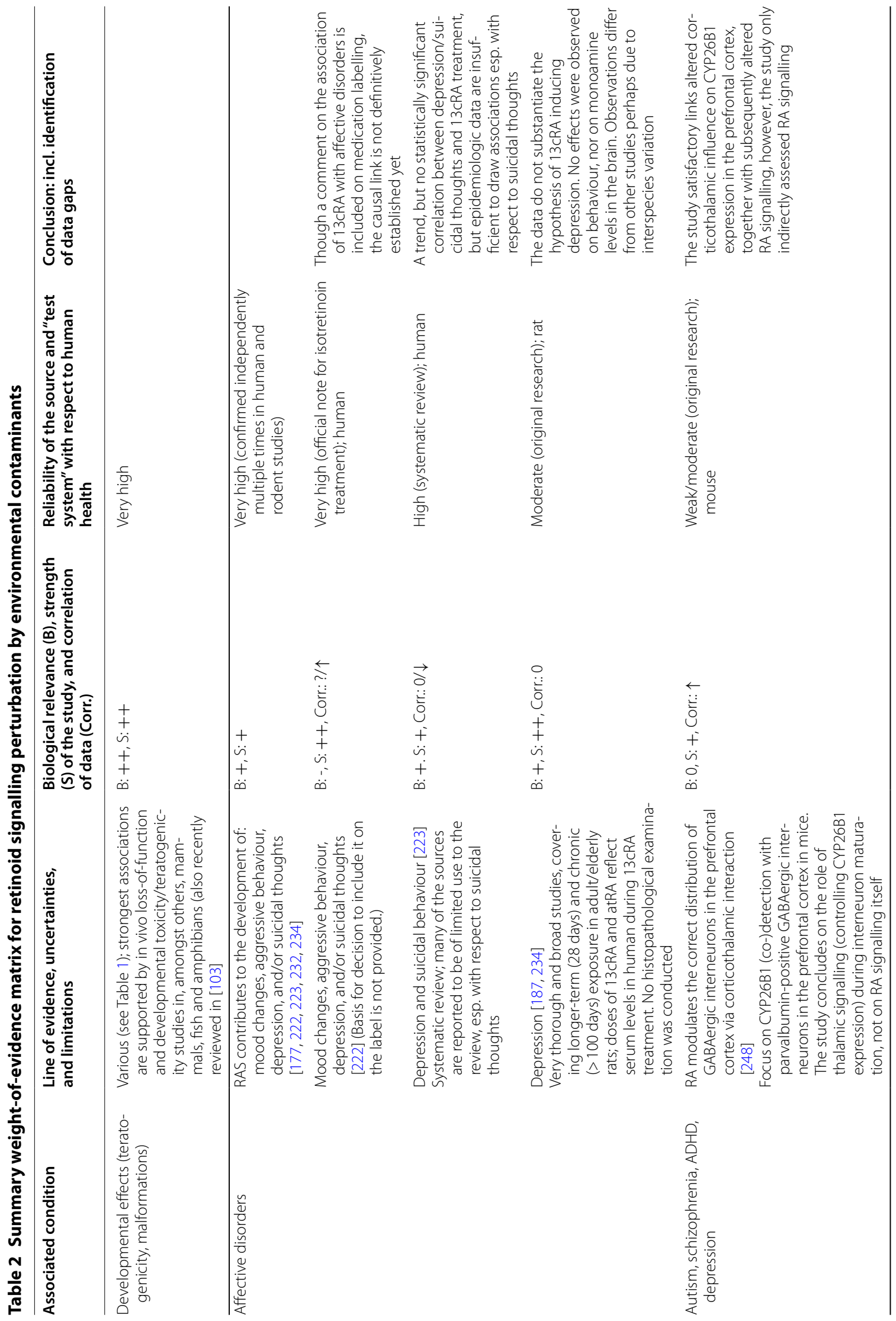




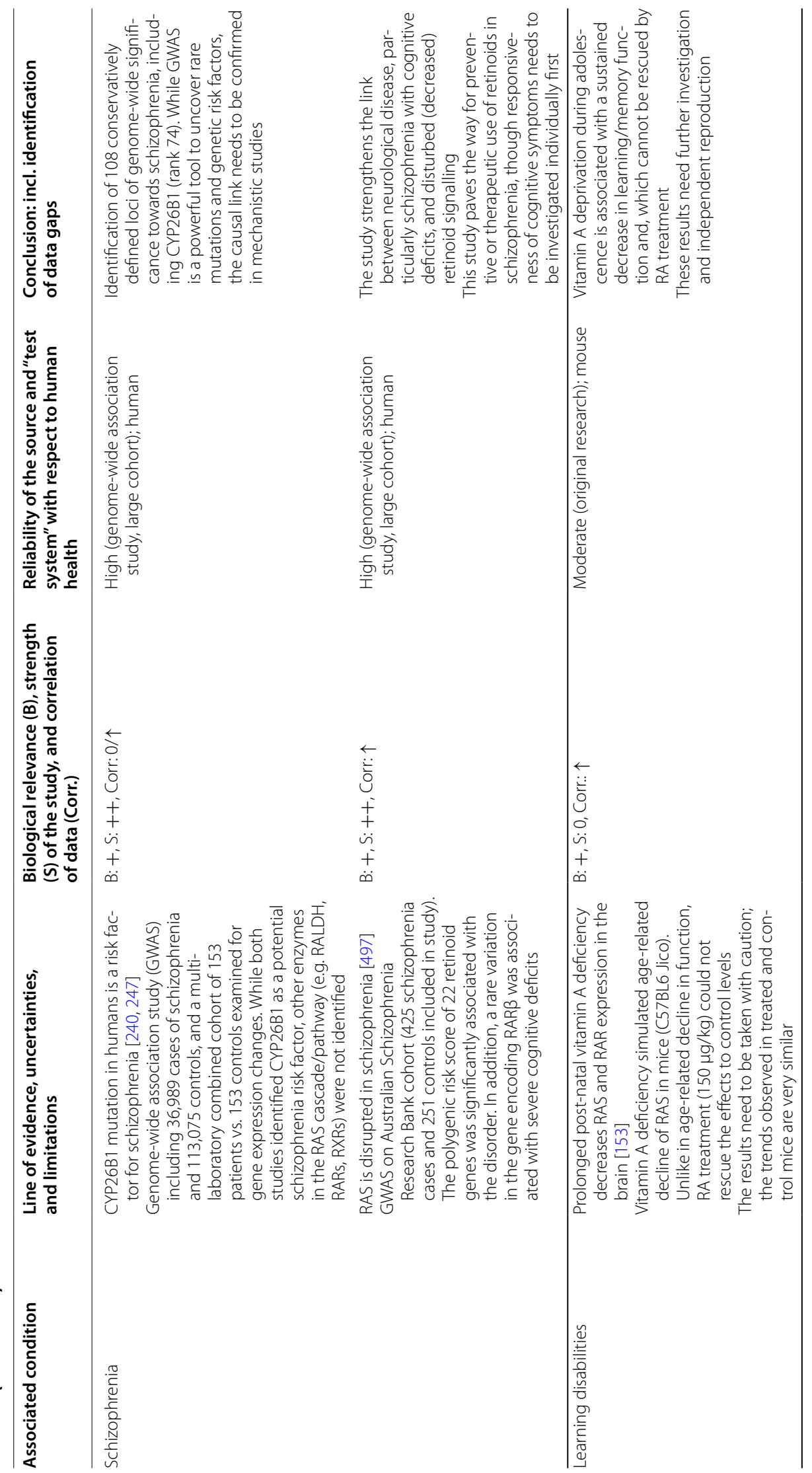




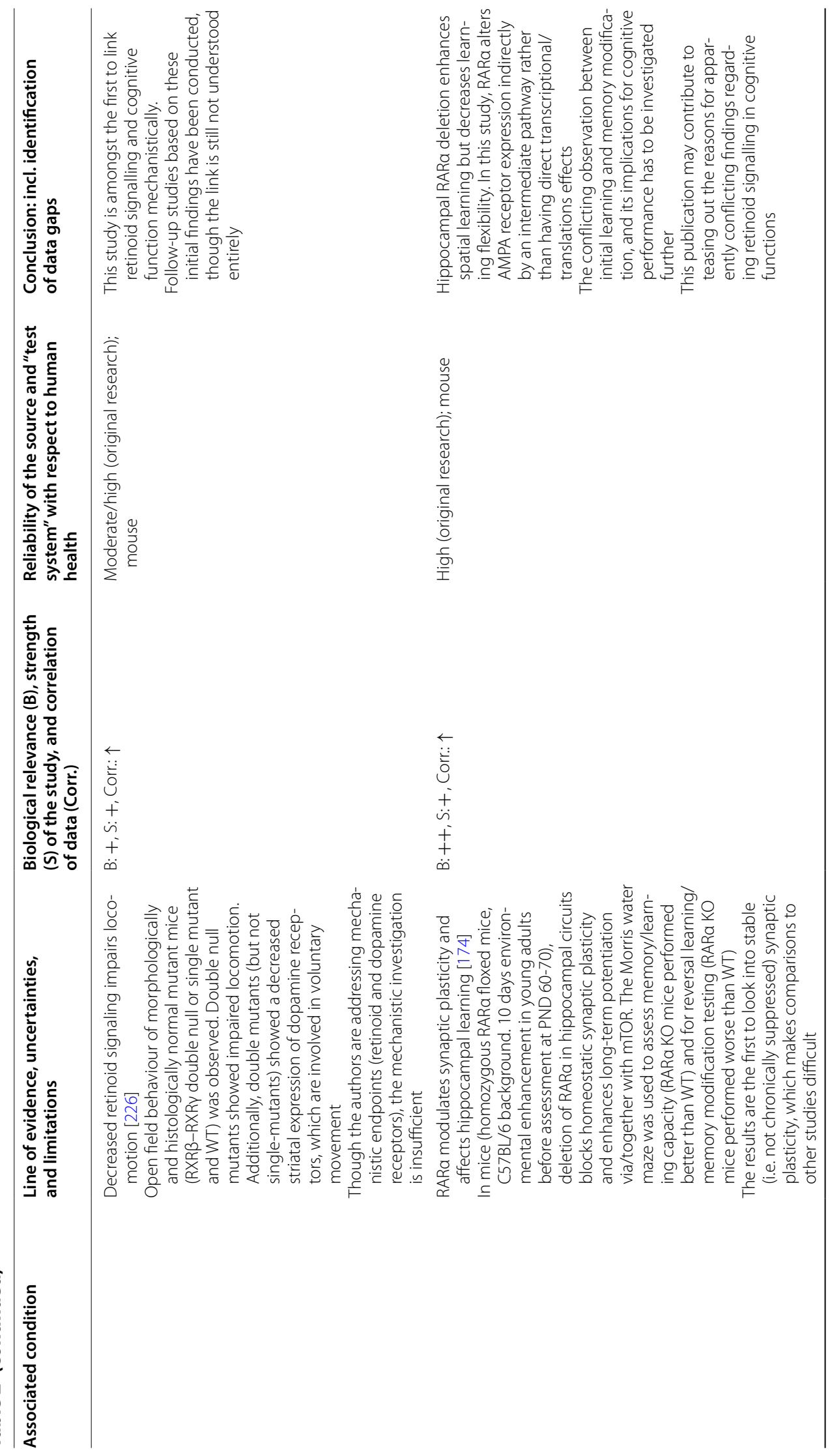




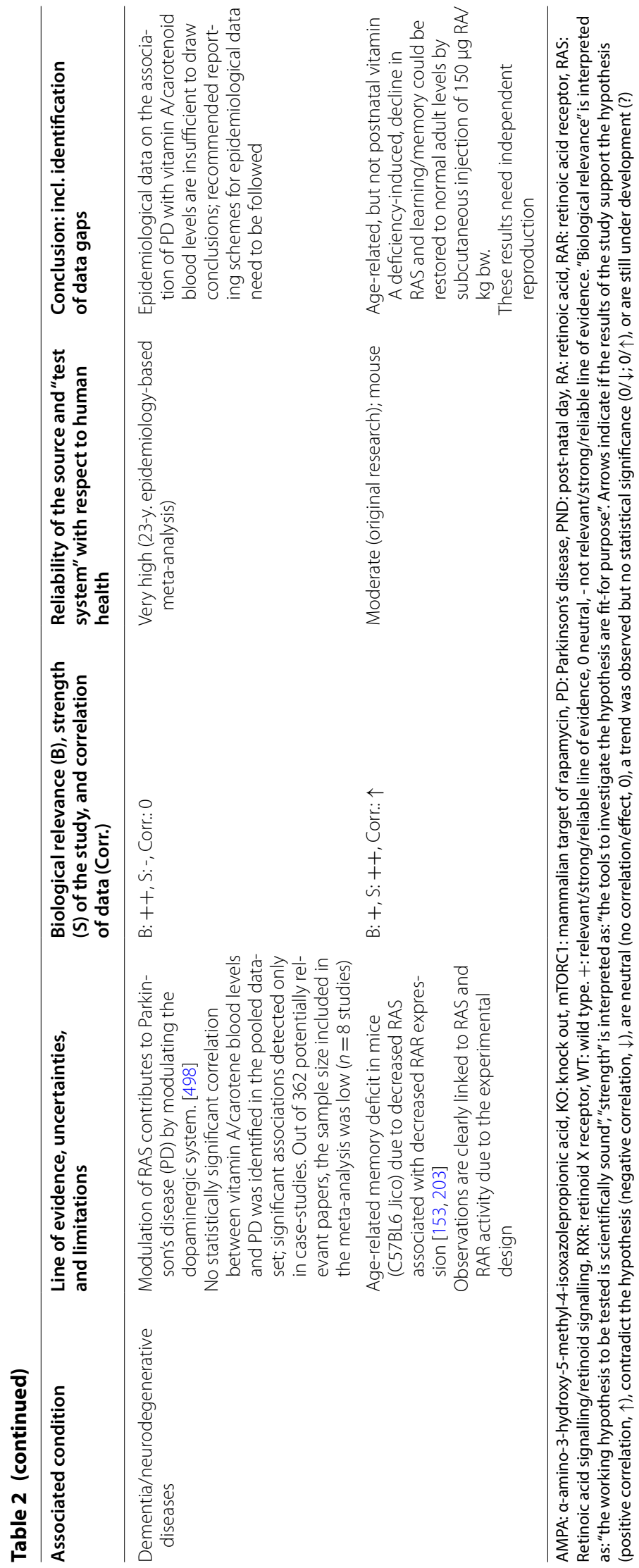


The impact of substances such as pesticides, fertilizers, and pharmaceuticals upon the growth of cyanobacterial blooms causing increased "anthropo-natural" retinoid production is also a critical factor to include in the hazard and risk assessment process.

\section{Discussion - implications for risk assessment}

We have presented evidence here indicating that altered endogenous retinoid signalling is plausibly implicated in a variety of major public health areas of concern. In particular these include brain and neurodegenerative conditions such as Parkinson's disease, dementia, schizophrenia, and depression (see sections "Contribution of retinoids to chronic neurological disorders"-"Schizophrenia", Tables 1 and 2), as well as developmental effects. However, the available evidence causally linking these diseases with aberrant retinoid signalling is currently weak - particularly with respect to environmental exposure.

Retinoids in the form of vitamin A and its precursors are essential nutritional requirements, and it is well established that too little or too much can lead to adverse health outcomes. Whilst vitamin A dietary reference values are clearly specified [70, 72, 97], these are advisory and on the whole are not controlled by regulatory bodies, with the exception of fortified functional/novel foods, where fortification can impact upon vulnerable populations, as for example, with infant formula [71]. Retinoid-based orally administered pharmaceuticals can also contribute to the daily exposure, while not being accounted for by nutritional reference values [222]. Critical limitations in attributing altered retinoid signalling to environmental exposure are the lack of monitoring of retinoid compounds and virtual absence of effect-based screenings for retinoid-like activity, even though monitoring reports from the Czech Republic and Asia indicate significant (anthropo-)natural sources of retinoids [249$252,271]$. This data gap is aggravated by the retinoid signalling pathway not (yet) being included as a contributory pathway that can be adequately assessed by standardized test methods, as part of endocrine disruption hazard assessment and by the unknown hazards related to environmental mixtures of anthropogenic contaminants and (anthropo-)natural compounds adversely interfering with this pathway. Retinoid signalling is directly involved (via RAR) in a multitude of developmental, neurological and repair processes as well as indirectly via the universal heterodimerization partner RXR. This contributes to the non-linear intercommunication web of cause-effect relationships that are observed upon disturbed retinoid signalling and additionally allows pleiotropic effects through crosstalk with other pathways such as TR [114], or PPAR $\beta / \delta$ signalling [113] and steroidogenesis [7]. In addition, the substantial evidence for the teratogenicity of retinoids is usually addressed under developmental toxicity hazard assessment, rather than endocrine disruption per se (see Table 1), whilst the proposed adverse outcomes in relation to spermatogenesis and male reproduction [summarized in 13], fall under reproductive toxicity, and the biologically plausible hypothesis of involvement in the development and manifestation of neurological disease, under (developmental) neurotoxicity (see Table 2). Furthermore, the elucidation of the link between neurological disease and altered RA signalling also requires more basic investigation into the role of retinoid signalling in the brain (using experimental models and clinical investigations) together with populationbased studies - as has been done, e.g. for polychlorinated biphenyls [299, 300]. This would need a characterization of the exposure to compounds with potential retinoid signalling disruptive effects - as depicted in Table 2.

In addition to hazard assessment, the characterization and quantification of environmental levels of retinoid compounds and retinoid-like activity is key for the exposure evidence base needed to assess whether they are likely to pose a risk to the environment and human health. This needs to include a consideration of exceedance of vitamin A nutritional requirements and dietary sources of exposure. (Anthropo-)natural sources of EAS such as cyanobacterial blooms often exhibit pronounced cyclic recurrent (i.e. seasonal, non-continuous) patterns [270, 301]. Consequently, derived exposure limits should consider intermediate longer-term values in addition to lifetime-daily exposure, such as seasonal, monthly, or weekly exposure. This has been recently proposed and conducted by the WHO for a few selected cyanobacterial toxins [270]. In surface waters, wastewater treatment effluents are a constant contributor of anthropogenic bioactive compounds including retinoids [253]. To address transformation of pharmaceutically and cosmetically used retinoids, it is suggested that work being initiated at the OECD to develop a test guideline on anaerobic transformation of veterinary pharmaceuticals, organic compounds and biocides in liquid farmyard manure [302] could include retinoid-like monitoring endpoints. This would contribute to filling the assessment data gap of retinoid-like activity originating from farmyard manure and its fate in the environment. This could also be a tool of potential value in addressing subsequent monitoring of retinoid removal in urban wastewater effluents.

Besides recognizing the occurrence of endocrine disruptors in the environment, it is also critical to develop more accurate tools to assess their potential impact and hence any associated risk. In the case of interference with retinoid signalling, this means mainly to direct research efforts into the augmentation of already existing test 


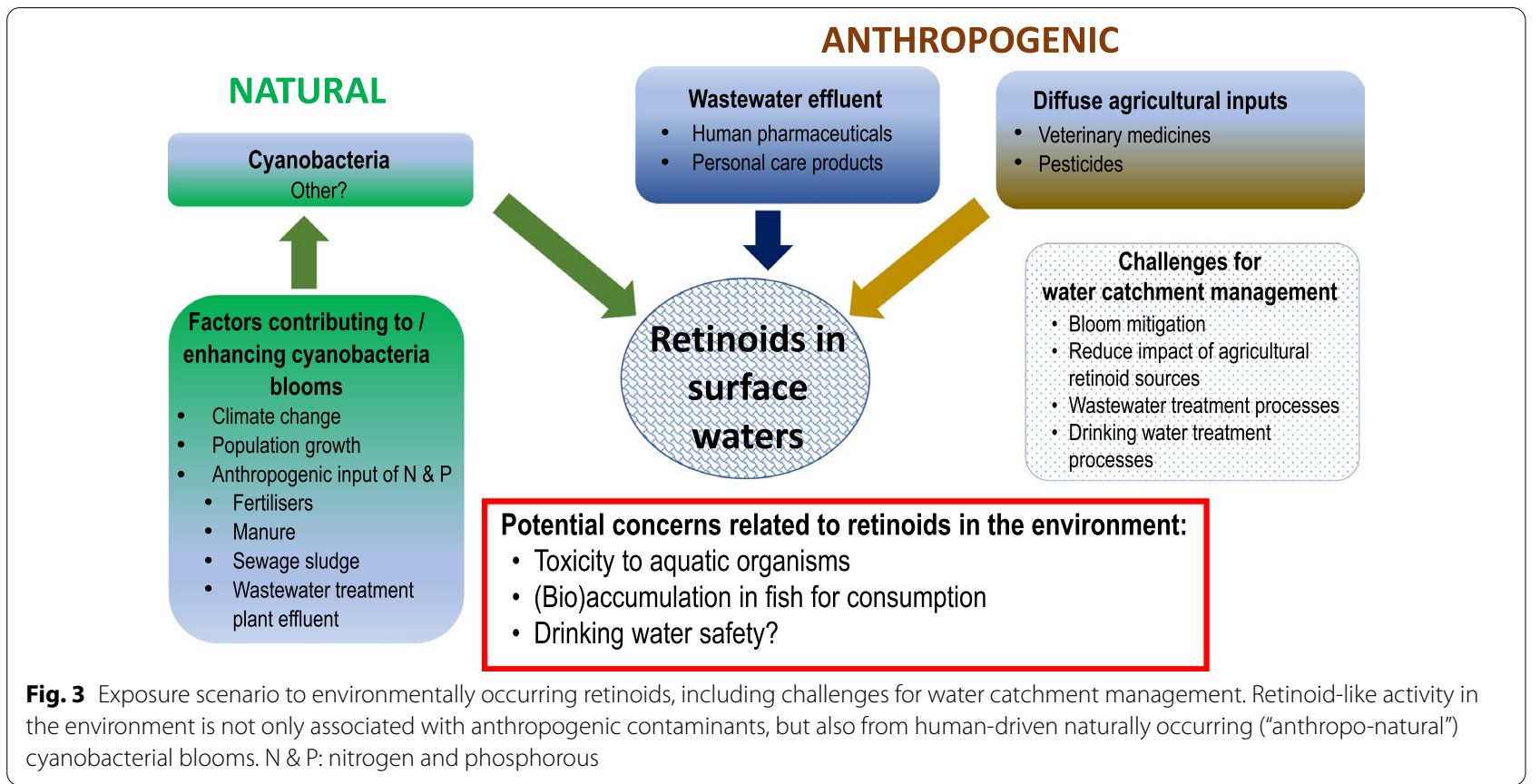

guidelines and the validation of (non-animal alternative) methods for regulatory testing of retinoid signalling pathway disruption, which is already initiated at international intergovernmental levels (see "Introduction" section).

In addition to distinct test methods, AOPs are being developed with the intention of regulatory applications, to convey biologically plausible hierarchical structures of causes, effects, and outcomes from basic research to regulatory actions. It is important to refine and strengthen AOPs under development for retinoid signalling disturbance $[13,303]$. Besides only linking the sequential "event-train", recent efforts to define tipping points for transition between key events could make AOPs become quantitative, thus more useful for computational predictive approaches [21, 303, 304]. An analogous approach to AOPs has also been taken in exposure science with aggregate exposure pathways (AEPs). They aim to summarize exposure from different sources, and integrate target site exposure, e.g. at a receptor in the tissue [305]. AEPs take into account potential environmental or metabolic transformation of a substance or cumulative effects of structurally similar substances in mixtures and are inclusive to substances of natural origin that may contribute to target site effects $[305,306]$. The integration of exposure and effect assessment is also called for by European partnerships to achieve the ambitious goals laid out in the WFD [307].

Substances of emerging concern often show endocrine activity and/or are candidate endocrine disruptors [308, 309]. Although not intended, these substances often find their way into the environment, and, most importantly their environmental occurrence is augmented by human actions [309]. For the sustainable development of society, we need to recognize our environmental impact and try to retain or re-establish the delicate balance of maintaining and protecting landscapes and ecosystems (see Fig. 3). Only then will we be able to achieve the visionary milestones identified and articulated, e.g. by the United Nations Organization as the "Sustainable Development Goals" [310, Goal 6: "Clean water and sanitation"], by the European Commission in water-related directives (e.g. WFD [291], DWD [294]) and, most recently, by the European Green Deal, which aims at ensuring a "toxicfree environment", including a zero pollution approach and the development of an action plan regarding endocrine disruptors in the environment and circular economies [311]. With respect to mixtures in the environment, it was recently proposed to combine all EU chemicalrelated legislation, independent of the use scenario, in order to allow an inclusive mixture impact assessment [312]. A further proposal is to formulate "human health protection goals", similar to the protection goals defined in the WFD for aquatic environments, with respect to involuntary and cumulative exposure to chemicals [312].

\section{Conclusion}

Here, we have presented the (anthropo-)natural occurrence of retinoids in freshwater environments as a case study example to highlight the importance of regulatory recognition of non-EATS endocrine disruption pathways, 
specifically the retinoid signalling pathway. Elaborating on diffuse and especially (anthropo-)natural sources of these teratogenic EAS, we highlight the necessity of including exposure to mixtures from different environmental media and evaluating environmental and human health impacts of compounds, irrespective of and independent to their initial use, e.g. biocide/plant protection product; environmental matrices like water or soil are indifferent to the use-case of a product.

The (anthropo-)natural occurrence and production of retinoids in water bodies in addition to anthropogenic sources suggests a human health hazard. However, due to insufficient data on environmental levels of retinoids, especially spatio-temporal screening data, an adequate risk assessment cannot be conducted to date. Future monitoring studies need to take into account both point sources such as wastewater treatment plants and diffuse (anthropo-)natural sources of EAS that include retinoids.

The retinoid signalling pathway is conserved at least across vertebrates and plays a pivotal role during prenatal development, such that its disturbance can cause teratogenic effects that range from mild malformations to lethality. Phenotypically similar developmental defects were observed in aquatic vertebrates exposed to environmental cyanobacterial bloom extracts with retinoid-like activity.

Postnatal roles of retinoids include epithelial integrity and spermatogenesis, and retinoid signalling disruption may play a role in the epidemic of neurological and neurodegenerative disease. A preliminary weight-ofevidence matrix for the association of disturbed retinoid signalling with neurological disease was presented to flag uncertainties in the experimental design or the biological link, however despite biological plausibility, the weight of evidence to date is insufficient to support the causality of retinoid signalling disturbance in neurological diseases.

Also, agonistic/antagonistic and additive actions that are not covered by the current assessment methods may occur due to the high degree of molecular crosstalk between different endocrine signalling pathways, as depicted for example for RXR.

To strengthen the retinoid relevant AOPs for regulatory applications, future toxicological studies need to further address and elucidate the toxicological tipping points from one key event to the next. Understanding the adaptive stress response in a concentration and timedependent manner is crucial to derive not only acute and chronic (i.e. life-time daily) exposure limits, but also more realistic prolonged-short time exposure limits that, for example, reflect seasonal variations in exposure scenarios as recently conducted by WHO [270], although retinoids are not currently included in this proposed approach. It may also lead to a better understanding of life-stage and gender differences in toxic effects. The development of high-throughput methods and an increasing number of validated non-animal methods will enable more rapid and efficient understanding of these differences that could ultimately contribute to safer waters in the future for humans and ecosystems.

\begin{abstract}
Abbreviations
9CRA: 9-cis Retinoic acid, alitretinoin; 13cRA: 13-cis Retinoic acid, isotretinoin; AD: Alzheimer's disease; AEP: Aggregate exposure pathway; AOP: Adverse outcome pathway; AR: Androgen receptor; atRA: All-trans retinoic acid, tretinoin; BDNF: Brain-derived neurotropic factor; CAR: Constitutive androstane receptor; CNS: Central nervous system; CYP26: Cytochrome P450 monooxygenase subfamily 26 (detoxifying enzyme); D1R, D2R: Dopamine receptors 1 and 2; DWD: Drinking Water Directive; EAS: Endocrine-active substances; EATS: Sex hormone (oestrogen, androgen) receptors, steroidogenesis, and thyroid hormone signalling; EC: European Commission; EC20: Effective concentration affecting $20 \%$ of the tested population; ER: Oestrogen receptor; GABA: $y$-Amino butyric acid; OECD: Organisation for Economic Co-operation and Development; PPAR: Peroxisome-proliferator activated receptor; PXR: Pregnane X receptor; RA: Retinoic acid; RALDH: Retinal dehydrogenase; RAR: Retinoic acid receptor; RARE: Retinoic acid-responsive element; REQ: atRA equivalent; RXR: Retinoid $X$ receptor; TG: Test guideline; TH: Thyroid hormone; TR: Thyroid hormone receptor; VAD: Vitamin A (retinol) deficiency; VDR: Vitamin D receptor; WFD: Water Framework Directive; WHO: World Health Organization.
\end{abstract}

\section{Acknowledgements}

Not applicable.

\section{Disclaimer}

The opinions are those of the authors' and not necessarily the organisations' involved. The European Union's Research Executive Agency cannot be held responsible for any use that may be made of the information it contains.

\section{Authors' contributions}

Conceptualization: BK, CR, KH, MNJ. Methodology: BK, MNJ. Writing - original draft preparation, BK. Writing - review and editing: $M N J, K H, C R$, and BK. Supervision: MNJ and KH. Funding acquisition: KH, CR. All authors read and approved the final manuscript.

\section{Funding}

The research has received funding from the Czech Science Foundation, Czechia, project No. 18-15199S, the RECETOX Research Infrastructure (Projects LM2018121 and the CETOCOEN EXCELLENCE Teaming 2 project supported by European Union's Horizon 2020 (857560) and the Czech Ministry of Education, Youth and Sports (02.1.01/0.0/0.0/18_046/0015975)), the European Union's Horizon 2020 research and innovation program under the Marie SkłodowskaCurie grant agreement No. $722493 \mathrm{NaToxAq}$ (BK), and grant agreement No. 825,753 ERGO (KH). MNJ was supported by Public Health England, CR did not receive specific funding for this study. The European Union's Research Executive Agency was not involved in any step of the study design.

Availability of data and materials

Not applicable.

Ethics approval and consent to participate

Not applicable.

\section{Consent for publication}

Not applicable.

\section{Competing interests}

The authors declare no conflict of interest. MNJ is on the Scientific Advisory Board of ERGO.

\section{Author details}

${ }^{1}$ Masaryk University, Faculty of Science, RECETOX, Kamenice 753/5, 62500 Brno, Czech Republic. ${ }^{2}$ Fera Science Ltd. (Fera), Sand Hutton, York, UK. 
${ }^{3}$ Department of Toxicology, Centre for Radiation, Chemical and Environmental, Hazards Public Health England, Chilton, Oxfordshire, UK.

Received: 4 August 2020 Accepted: 30 October 2020 Published online: 13 February 2021

\section{References}

1. European Commission (2018) Commission Regulation (EU) 2018/605 amending Annex II to Regulation (EC) No 1107/2009 by setting out scientific criteria for the determination of endocrine disrupting properties. https://doi.org/10.2903/j.efsa.2013.3132

2. EFSA, ECHA, with the technical support of the JRC, et al (2018) Guidance for the identification of endocrine disruptors in the context of Regulations (EU) No 528/2012 and (EC) No 1107/2009. EFSA J 16:e05311. https://doi.org/10.2903/j.efsa.2018.5311

3. OECD GD 150 (2018) Revised Guidance Document 150 on Standardised Test Guidelines for Evaluating Chemicals for Endocrine Disruption

4. La Merrill MA, Vandenberg LN, Smith MT et al (2020) Consensus on the key characteristics of endocrine-disrupting chemicals as a basis for hazard identification. Nat Rev Endocrinol 16:45-57. https://doi. org/10.1038/s41574-019-0273-8

5. Crain DA, Rooney AA, Orlando E, Guillette LJ (2000) Endocrine disrupting contaminants and hormone dynamics: lessons from wildlife. In: Guillette LJ, Crain DA (eds) Environmental endocrine disrupters: an evolutionary perspective. Taylor \& Francis, New York, p 355

6. Schug TT, Johnson AF, Birnbaum LS et al (2016) Minireview: endocrine Disruptors: Past Lessons and Future Directions. Mol Endocrinol 30:833-847. https://doi.org/10.1210/me.2016-1096

7. Jacobs MN (2005) Nutrients and cell signaling. CRC Press, New York

8. OECD DRP 97 (2008) Detailed Review Paper on the use of metabolising systems for in vitro testing of endocrine disruptors. In: OECD Series on Testing and Assessment. OECD, p 213

9. OECD DRP 178 (2014) Detailed Review Paper on the state of the science on novel in vitro and in vivo screening and testing methods and endpoints for evaluating endocrine disruptors. In: OECD Series on Testing and Assessment. OECD

10. OECD (2017) New scoping document on in vitro and ex vivo assays for the identification of modulators of thyroid hormone signalling. In: OECD Series on Testing and Assessment, No. 207

11. Greally JM, Jacobs MN (2013) In vitro and in vivo testing methods of epigenomic endpoints for evaluating endocrine disruptors. Altex 30:445-471. https://doi.org/10.14573/altex.2013.4.445

12. Jacobs MN, Marczylo EL, Guerrero-Bosagna C, Uegg JR (2017) Marked for life: epigenetic effects of endocrine disrupting chemicals. Annu Rev Environ Resour 42:1-23. https://doi.org/10.1146/annurev-environ

13. Nilsson C (2020) Retinoids in Mammalian Reproduction, with an Initial Scoping Effort to Identify Regulatory Methods. TemaNord 2020:507. Nordic Council of Ministers

14. Grignard E, Hakansson H, Munn S (2020) Regulatory needs and activities to address the retinoid system in the context of endocrine disruption: the European viewpoint. Reprod Toxicol 93:250-258. https://doi. org/10.1016/j.reprotox.2020.03.002

15. Jacobs MN, Laws SC, Willett K, et al (2013) In vitro metabolism and bioavailability tests for endocrine active substances: What is needed next for regulatory purposes? Altex 30:331-351. https://doi.org/10.14573/ altex.2013.3.331

16. Jacobs M, Janssens W, Bernauer $U$ et al (2008) The use of metabolising systems for in vitro testing of endocrine disruptors. Curr Drug Metab 9:796-826. https://doi.org/10.2174/138920008786049294

17. Vandenberg LN, Colborn T, Hayes TB et al (2012) Hormones and endocrine-disrupting chemicals: low-dose effects and nonmonotonic dose responses. Endocr Rev 33:378-455

18. Bergman $\AA$, Heindel JJ, Jobling S et al (2013) Endocrine disruptors and metabolic disorders. State Sci Endocr Disrupt Chem 2012:296

19. Marczylo EL, Jacobs MN, Gant TW (2016) Environmentally induced epigenetic toxicity: potential public health concerns. Crit Rev Toxicol 46:676-700
20. Legler J, Zalko D, Jourdan F et al (2020) The GOLIATH project: towards an internationally harmonised approach for testing metabolism disrupting compounds. Int J Mol Sci 21:3480. https://doi.org/10.3390/ ijms 21103480

21. Jacobs MN, Colacci A, Corvi R et al (2020) Chemical carcinogen safety testing: OECD expert group international consensus on the development of an integrated approach for the testing and assessment of chemical non-genotoxic carcinogens. Arch Toxicol 1:3. https://doi. org/10.1007/s00204-020-02784-5

22. Bergman $\AA$, Heindel JJ, Kasten T et al (2013) The impact of endocrine disruption: a consensus statement on the state of the science. Environ Health Perspect. https://doi.org/10.1289/ehp.1205448

23. Schug TT, Janesick A, Blumberg B, Heindel JJ (2011) Endocrine disrupting chemicals and disease susceptibility. J Steroid Biochem Mol Biol 127:204-215

24. Li M, Sun Y, Guan X et al (2014) Advanced progress on the relationship between RA and its receptors and malignant tumors. Crit Rev Oncol Hematol 91:271-282

25. Stel J, Legler J (2015) The role of epigenetics in the latent effects of early life exposure to obesogenic endocrine disrupting chemicals. Endocrinology 156:3466-3472. https://doi.org/10.1210/en.2015-1434

26. Heindel JJ, Blumberg B, Cave M et al (2017) Metabolism disrupting chemicals and metabolic disorders. Reprod Toxicol 68:3-33. https://doi. org/10.1016/j.reprotox.2016.10.001

27. Trasande L, Blumberg B (2018) Endocrine disruptors as obesogens. In: Contemporary Endocrinology. Humana Press Inc., pp 243-253

28. Jacobs MN, Colacci A, Louekari K, et al (2016) International regulatory needs for development of an IATA for non-genotoxic carcinogenic chemical substances. Altex 33:359-392. https://doi.org/10.14573/altex .1601201

29. Murphy KA, Villano CM, Dorn R, White LA (2004) Interaction between the aryl hydrocarbon receptor and retinoic acid pathways increases matrix metalloproteinase-1 expression in keratinocytes. J Biol Chem 279:25284-25293. https://doi.org/10.1074/jbc.M402168200

30. Gormley Á, Pollard S, Rocks S, Black E (2011) Guidelines for Environmental Risk Assessment and Management - Green Leaves III

31. Scientific Committee EFSA, More SJ, Bampidis V et al (2019) Guidance on harmonised methodologies for human health, animal health and ecological risk assessment of combined exposure to multiple chemicals. EFSA J 17:77. https://doi.org/10.2903/j.efsa.2019.5634

32. EURION (2018) Improving Identification of Endocrine Disruptors. https //eurion-cluster.eu/. Accessed 24 Feb 2020

33. Jobling S, Beresford N, Nolan M et al (2002) Altered Sexual Maturation and Gamete Production in Wild Roach (Rutilus rutilus) Living in Rivers That Receive Treated Sewage Effluents1. Biol Reprod 66:272-281. https ://doi.org/10.1095/biolreprod66.2.272

34. Tyler CR, Jobling S, Sumpter JP (1998) Endocrine disruption in wildlife: a critical review of the evidence. Crit Rev Toxicol 28:319-361

35. Semenza JC, Tolbert PE, Rubin CH et al (1997) Reproductive toxins and alligator abnormalities at Lake Apopka, Florida. Environ Health Perspect 105:1030-1032

36. Purdom CE, Hardiman PA, Bye VJ et al (1994) Estrogenic Effects of Effluents from Sewage Treatment Works. Chemistry and Ecology 8:275-285. https://doi.org/10.1080/02757549408038554

37. Harris CA, Hamilton PB, Runnalls TJ et al (2011) The consequences of feminization in Breeding groups of wild fish. Environ Health Perspect 119:306-311. https://doi.org/10.1289/ehp.1002555

38. Jobling S, Nolan M, Tyler CR et al (1998) Widespread sexual disruption in wild fish. Environ Sci Technol 32:2498-2506. https://doi.org/10.1021/ es9710870

39. Kidd KA, Blanchfield PJ, Mills KH et al (2007) Collapse of a fish population after exposure to a synthetic estrogen. Proc Natl Acad Sci USA 104:8897-8901. https://doi.org/10.1073/pnas.0609568104

40. Shore LS, Gurevitz M, Shemesh M (1993) Estrogen as an environmental pollutant. Bull Environ Contam Toxicol 51:361-366. https://doi. org/10.1007/BF00201753

41. Schwarz TI, Katsiadaki I, Maskrey BH, Scott AP (2018) Uptake and metabolism of water-borne progesterone by the mussel, Mytilus spp. (Mollusca). J Steroid Biochem Mol Biol 178:13-21. https://doi. org/10.1016/j.jsbmb.2017.10.016 
42. Marty MS, Carney EW, Rowlands JC (2011) Endocrine disruption: historical perspectives and its impact on the future of toxicology testing. Toxicol Sci 120:S93-S108. https://doi.org/10.1093/toxsci/kfa329

43. WHO/UNEP (2013) State of the science of endocrine disrupting chemicals - 2012. An assessment of the state of the science of endocrine disruptors prepared by a group of experts for the United Nations Environment Programme (UNEP) and WHO. ISBN: 9789241505031

44. Solecki R, Kortenkamp A, Bergman Å et al (2017) Scientific principles for the identification of endocrine-disrupting chemicals: a consensus statement. Arch Toxicol 91:1001-1006. https://doi.org/10.1007/s0020 4-016-1866-9

45. OECD (2015) Test No. 493: Performance-Based Test Guideline for Human Recombinant Estrogen Receptor (hrER) In Vitro Assays to Detect Chemicals with ER Binding Affinity, OECD Guidelines for the Testing of Chemicals, Section 4, OECD Publishing, Paris. https://doi. org/10.1787/9789264242623-en

46. OECD (2015) Test No. 455: Performance-Based Test Guideline for Stably Transfected Transactivation In Vitro Assays to Detect Estrogen Receptor Agonists and Antagonists, OECD Publishing, Paris. https://doi. org/10.1787/9789264243040-en

47. OECD (2007) Test No. 440: Uterotrophic Bioassay in Rodents: A shortterm screening test for oestrogenic properties, OECD Guidelines for the Testing of Chemicals, Section 4, OECD Publishing, Paris. https://doi. org/10.1787/9789264067417-en

48. OECD (2007) Guidance Document on the uterotrophic bioassay procedure to test for Antioestrogenicity. ENV/JM/MONO(2007)15. JT03230411. In: OECD Series on Testing and Assessment. OECD Publishing, Paris. http://www.oecd.org/officialdocuments/publicdisplaydo cumentpdf/?cote $=$ env $/ \mathrm{jm} / \mathrm{mono}(2007) 15 \&$ doclanguage $=e n$

49. OECD (2020) Test No. 458: Stably Transfected Human Androgen Receptor Transcriptional Activation Assay for Detection of Androgenic Agonist and Antagonist Activity of Chemicals, OECD Guidelines for the Testing of Chemicals, Section 4, OECD Publishing, Paris. https://doi. org/10.1787/9789264264366-en

50. OECD (2011) Guidance document on the androgenised female stickleback screen. JT03305970. ENV/JM/MONO(2011)29. In: OECD Series on Testing and Assessment: Testing for Endocrine Disrupters No. 148. OECD Publishing, Paris. http://www.oecd.org/officialdocuments/publi cdisplaydocumentpdf/?cote=ENV/JM/MONO(2011)29\&doclanguag $\mathrm{e}=\mathrm{en}$

51. OECD (2009) Test No. 441: Hershberger Bioassay in Rats: A Short-term Screening Assay for (Anti)Androgenic Properties, OECD Guidelines for the Testing of Chemicals, Section 4, OECD Publishing, Paris. https://doi. org/10.1787/9789264076334-en

52. OECD (2009) Test No. 230: 21-day Fish Assay: A Short-Term Screening for Oestrogenic and Androgenic Activity, and Aromatase Inhibition, OECD Guidelines for the Testing of Chemicals, Section 2, OECD Publishing, Paris. https://doi.org/10.1787/9789264076228-en

53. OECD (2010) Validation report on the 21-day androgenised female stickleback screening assay. In: Series on Testing and Assessment: Testing for Endocrine Disrupters No. 128. ENV/JM/MONO(2010)19. OECD Publishing, Paris. http://www.oecd.org/officialdocuments/publicdisp laydocumentpdf/?cote $=$ env/jm/mono(2010) $19 \&$ doclanguage $=e n$

54. Jolly C, Katsiadaki I, Morris S et al (2009) Detection of the anti-androgenic effect of endocrine disrupting environmental contaminants using in vivo and in vitro assays in the three-spined stickleback. Aquat Toxicol 92:228-239. https://doi.org/10.1016/j.aquatox.2009.02.006

55. Katsiadaki I, Morris S, Squires C et al (2006) Use of the three-spined stickleback (Gasterosteus aculeatus) as a sensitive in vivo test for detection of environmental antiandrogens. Environ Health Perspect 114:115-121. https://doi.org/10.1289/ehp.8063

56. Kurauchi K, Hirata T, Kinoshita M (2008) Characteristics of ChgH-GFP transgenic medaka lines, an in vivo estrogenic compound detection system. Mar Pollut Bull 57:441-444. https://doi.org/10.1016/j.marpo |bul.2008.03.016

57. Kurauchi K, Nakaguchi Y, Tsutsumi M et al (2005) In vivo visual reporter system for detection of estrogen-like substances by transgenic medaka. Environ Sci Technol 39:2762-2768. https://doi.org/10.1021/es0486465

58. Spirhanzlova P, Leleu M, Sébillot A et al (2016) Oestrogen reporter transgenic medaka for non-invasive evaluation of aromatase activity.
Comparative Biochem Physiol 179:64-71. https://doi.org/10.1016/j. cbpc.2015.08.011

59. Brion $F$ (2017) Draft report of the phase 1 validation study of the EASZY assay. In: National Institute of Industrial Environment and Risks (INERIS) Chronic Risk Division. France. pp 1-12

60. Kiianitsa K, Maizels N (2013) A rapid and sensitive assay for DNA-protein covalent complexes in living cells. Nucleic Acids Res 41:e104. https:// doi.org/10.1093/nar/gkt171

61. Sébillot A, Damdimopoulou P, Ogino Y et al (2014) Rapid fluorescent detection of (anti)androgens with spiggin-gfp medaka. Environ Sci Technol 48:10919-10928. https://doi.org/10.1021/es5030977

62. Browne P, Judson RS, Casey WM et al (2015) Screening chemicals for estrogen receptor bioactivity using a computational model. Environ Sci Technol 49:8804-8814. https://doi.org/10.1021/acs.est.5b02641

63. Kleinstreuer NC, Browne P, Chang X et al (2018) Evaluation of androgen assay results using a curated Hershberger database. Reprod Toxicol 81:272-280. https://doi.org/10.1016/j.reprotox.2018.08.017

64. OECD (2011) Test No. 456: H295R Steroidogenesis Assay, OECD Guidelines for the Testing of Chemicals, Section 4, OECD Publishing, Paris. https://doi.org/10.1787/9789264122642-en

65. EURL ECVAM (2017) European drive to validate in vitro methods for the detection of thyroid disruptors| EU Science Hub. https://ec.europa.eu/ $\mathrm{jrc/en/science-update/vitro-methods-detection-thyroid-disruptors.}$ Accessed 2 Jul 2020

66. JRC (2017) Thyroid receptor microarray assay for real-time Nuclear Receptor-coregulator interaction| EURL ECVAM - TSAR. https://tsar.jrc. ec.europa.eu/test-method/tm2017-02. Accessed 2 Jul 2020

67. OECD (2019) Test No. 248: Xenopus Eleutheroembryonic Thyroid Assay (XETA), OECD Guidelines for the Testing of Chemicals, Section 2, OECD Publishing, Paris. https://doi.org/10.1787/a13f80ee-en

68. Fini JB, Le Mevel S, Turque $\mathrm{N}$ et al (2007) An in vivo multiwell-based fluorescent screen for monitoring vertebrate thyroid hormone disruption. Environ Sci Technol 41:5908-5914. https://doi.org/10.1021/es070 4129

69. IUPAC (1983) Nomenclature of retinoids. Pure Appl Chem 55:721-726

70. SCCS (2016) Opinion on vitamin A (retinol, retinyl acetate, retinyl palmitate). Final version of 6 October 2016, CORRIGENDUM on 23 December 2016. SCCS/1576/16 1-85. https://doi.org/10.2875/642264

71. COT (2014) Committee on toxicity of chemicals in food, consumer products and the environment: statement on the potential risks from high levels of vitamin A in the infant diet. COT Statement 2013(03):1-28

72. PHE (2016) Government dietary recommendations. Government recommendations for energy and nutrients for males and females aged $1-18$ years and $19+$ years. PHE publications; Nutrition Science TeamNutrition Science Team

73. Rhinn M, Dollé $P$, Dolle $P$ (2012) Retinoic acid signalling during development. Development 139:843-858. https://doi.org/10.1242/dev.065938

74. Bryant SV, Gardiner DM (1992) Retinoic acid, local cell-cell interactions, and pattern formation in vertebrate limbs. Develop Biol 152:1-25. https ://doi.org/10.1016/0012-1606(92)90152-7

75. Zieger E, Schubert M (2017) New insights into the roles of retinoic acid signaling in nervous system development and the establishment of neurotransmitter systems. In: International review of cell and molecular biology(330). pp 1-84

76. Maden M (2000) The role of retinoic acid in embryonic and postembryonic development. Proc Nutr Soc 59:65-73

77. Maden M (1993) The effect of vitamin A (retinoids) on pattern formation implies a uniformity of developmental mechanisms throughout the animal kingdom. Acta Biotheor 41:425-445. https://doi. org/10.1007/BF00709375

78. Cunningham TJ, Duester G (2015) Mechanisms of retinoic acid signalling and its roles in organ and limb development. Nat Rev Mol Cell Biol 16:110-123. https://doi.org/10.1038/nrm3932

79. Gardiner D, Ndayibagira A, Grün F, Blumberg B (2003) Deformed frogs and environmental retinoids. In: Pure and Applied Chemistry. De Gruyter, pp 2263-2273

80. Tzimas G, Nau H (2001) The role of metabolism and toxicokinetics in retinoid teratogenesis. Curr Pharm Des 7:803-831. https://doi. org/10.2174/1381612013397708

81. Hendrickx AG, Peterson P, Hartmann D, Hummler H (2000) Vita$\min A$ teratogenicity and risk assessment in the macaque retinoid 
model. Reprod Toxicol 14:311-323. https://doi.org/10.1016/s0890 $-6238(00) 00091-5$

82. Maden M (2007) Retinoic acid in the development, regeneration and maintenance of the nervous system. Nat Rev Neurosci 8:755-765. https ://doi.org/10.1038/nrn2212

83. Allenby G, Bocquel MT, Saunders M et al (1993) Retinoic acid receptors and retinoid $X$ receptors: interactions with endogenous retinoic acids. Proc Natl Acad Sci USA 90:30-34. https://doi.org/10.1073/pnas.90.1.30

84. Priebojová J, Hilscherová K, Procházková T et al (2018) Intracellular and extracellular retinoid-like activity of widespread cyanobacterial species. Ecotoxicol Environ Saf 150:312-319. https://doi.org/10.1016/j.ecoen v.2017.12.048

85. De Lera ÁR, Krężel W, Rühl R (2016) An endogenous mammalian retinoid $X$ receptor ligand, at Last! ChemMedChem 11:1027-1037. https:// doi.org/10.1002/cmdc.201600105

86. Dawson Ml, Xia Z (2012) The retinoid X receptors and their ligands. Biochem Biophys Acta 1821:21-56. https://doi.org/10.1016/j.bbali p.2011.09.014

87. Clark AK, Wilder JH, Grayson AW et al (2016) The Promiscuity of allosteric regulation of nuclear receptors by retinoid $X$ Receptor. J Phys Chem B 120:8338-8345. https://doi.org/10.1021/acs.jpcb.6b02057

88. Krężel W, Rühl R, de Lera AR (2019) Alternative retinoid X receptor (RXR) ligands. Mol Cell Endocrinol 491:110436

89. Sandell LL, Lynn ML, Inman KE et al (2012) RDH10 oxidation of vitamin $A$ is a critical control step in synthesis of retinoic acid during mouse embryogenesis. PLoS ONE 7:e30698. https://doi.org/10.1371/journ al.pone.0030698

90. Ribes V, Wang Z, Dollé P, Niederreither K (2006) Retinaldehyde dehydrogenase 2 (RALDH2)-mediated retinoic acid synthesis regulates early mouse embryonic forebrain development by controlling FGF and sonic hedgehog signaling. Development 133:351-361. https://doi. org/10.1242/dev.02204

91. Niederreither K, Vermot J, Schuhbaur B et al (2000) Retinoic acid synthesis and hindbrain patterning in the mouse embryo. Development 127:75-85

92. Lucek RW, Colburn WA (1985) Clinical pharmacokinetics of the retinoids. Clin Pharmacokinet 10:38-62. https://doi.org/10.2165/00003 088-198510010-00002

93. Shirakami Y, Lee SA, Clugston RD, Blaner WS (2012) Hepatic metabolism of retinoids and disease associations. Biochem Biophys Acta 1821:124-136

94. Blomhoff R, Blomhoff HK (2006) Overview of retinoid metabolism and function. J Neurobiol 66:606-630. https://doi.org/10.1002/neu.20242

95. Rodriguez-Concepcion M, Avalos J, Bonet ML et al (2018) A global perspective on carotenoids: metabolism, biotechnology, and benefits for nutrition and health. Prog Lipid Res 70:62-93

96. Morriss-Kay GM, Wardt SJ (1999) Retinoids and mammalian development. Int Rev Cytol 188:73-131. https://doi.org/10.1016/s0074 -7696(08)61566-1

97. EFSA NDA (2015) Scientific opinion on dietary reference values for vitamin A. EFSA panel on dietetic products, nutrition, and allergies (NDA) EFSA J 13:4028. https://doi.org/10.2903/j.efsa.2015.4028

98. Germain $\mathrm{P}$, Chambon $\mathrm{P}$, Eichele $\mathrm{G}$ et al (2006) International union of pharmacology. LX. Retinoic acid receptors. Pharmacol Rev 58:712-725

99. Das BC, Thapa P, Karki R et al (2014) Retinoic acid signaling pathways in development and diseases. Bioorg Med Chem 22:673-683. https://doi. org/10.1016/j.bmc.2013.11.025

100. Mouchon A, Delmotte M-H, Formstecher P, Lefebvre P (1999) Allosteric regulation of the discriminative responsiveness of retinoic acid receptor to natural and synthetic ligands by retinoid X receptor and DNA. Mol Cell Biol 19:3073-3085. https://doi.org/10.1128/mcb.19.4.3073

101. Vilhais-Neto GC, Pourquié O (2008) Retinoic acid. Curr Biol 18:R191-R192

102. le Maire Tet al (2019) Regulation of RXR-RAR heterodimers by RXR- and RAR-specific ligands and their combinations. Cells 8:1392. https://doi. org/10.3390/cells8111392

103. Ghyselinck NB, Duester G (2019) Retinoic acid signaling pathways. Development (Cambridge). https://doi.org/10.1242/dev.167502

104. Penvose A, Keenan JL, Bray D et al (2019) Comprehensive study of nuclear receptor DNA binding provides a revised framework for understanding receptor specificity. Nature Communications 10:2514. https://doi.org/10.1038/s41467-019-10264-3

105. Szanto A, Narkar V, Shen Q et al (2004) Review retinoid x receptors: $x$-ploring their (patho)physiological functions. Cell Death Differ 11:S126-S143

106. Cai Y, Konishi T, Han G et al (2002) The role of hepatocyte RXRa in xenobiotic-sensing nuclear receptor-mediated pathways. Eur J Pharm Sci 15:89-96. https://doi.org/10.1016/S0928-0987(01)00211-1

107. Evans RM, Mangelsdorf DJ (2014) Nuclear receptors, RXR, and the big bang. Cell 157:255-266

108. Gampe RT, Montana VG, Lambert MH et al (2000) Asymmetry in the PPARY/RXRa crystal structure reveals the molecular basis of heterodimerization among nuclear receptors. Mol Cell 5:545-555. https://doi. org/10.1016/S1097-2765(00)80448-7

109. Lee S-K, Na S-Y, Kim H-J et al (1998) Identification of critical residues for heterodimerization within the ligand-binding domain of retinoid X receptor. Mol Endocrinol 12:325-332. https://doi.org/10.1210/ mend.12.3.0072

110. Bourguet W, Vivat V, Wurtz JM et al (2000) Crystal structure of a heterodimeric complex of RAR and RXR ligand-binding domains. Mol Cell 5:289-298. https://doi.org/10.1016/S1097-2765(00)80424-4

111. André A, Ruivo R, Fonseca E et al (2019) The retinoic acid receptor (RAR) in molluscs: function, evolution and endocrine disruption insights. Aquat Toxicol 208:80-89. https://doi.org/10.1016/j.aquatox.2019.01.002

112. Al Tanoury Z, Piskunov A, Rochette-Egly C (2013) Vitamin a and retinoid signaling: genomic and nongenomic effects. J Lipid Res 54:1761-1775

113. Schug TT, Berry DC, Shaw NS et al (2007) Opposing effects of retinoic acid on cell growth result from alternate activation of two different nuclear receptors. Cell 129:723-733. https://doi.org/10.1016/j. cell.2007.02.050

114. Paul-Friedman K, Martin M, Crofton KM et al (2019) Limited Chemical Structural Diversity Found to Modulate Thyroid Hormone Receptor in the Tox21 Chemical Library. Environ Health Perspect 127:097009. https ://doi.org/10.1289/EHP5314

115. Pascussi J-M, Gerbal-Chaloin S, Duret C et al (2008) The tangle of nuclear receptors that controls xenobiotic metabolism and transport: crosstalk and consequences. Annu Rev Pharmacol Toxicol 48:1-32. https://doi.org/10.1146/annurev.pharmtox.47.120505.105349

116. Kakizaki S, Karami S, Negishi M (2002) Retinoic acids repress constitutive active receptor-mediated induction by 1,4-bis[2-(3,5-dichloropyridyloxy)]benzene of the CYP2B10 gene in mouse primary hepatocytes. Drug Metab Dispos 30:208-211. https://doi.org/10.1124/dmd.30.2.208

117. Dubuquoy L, Dharancy S, Nutten S et al (2002) Role of peroxisome proliferator-activated receptor $\gamma$ and retinoid $X$ receptor heterodimer in hepatogastroenterological diseases. Lancet 360:1410-1418

118. Hua S, Kittler R, White KP (2009) Genomic antagonism between retinoic acid and estrogen signaling in breast cancer. Cell 137:1259-1271. https ://doi.org/10.1016/j.cell.2009.04.043

119. Segars JH, Marks MS, Hirschfeld S et al (1993) Inhibition of estrogenresponsive gene activation by the retinoid $\mathrm{X}$ receptor beta: evidence for multiple inhibitory pathways. Mol Cell Biol 13:2258-2268. https:// doi.org/10.1128/mcb.13.4.2258

120. Rubin M, Fenig E, Rosenauer A et al (1994) 9-Cis retinoic acid inhibits growth of breast cancer cells and down-regulates estrogen receptor RNA and protein. Cancer Res 54:6549-6556

121. Rousseau C, Nichol JN, Pettersson F et al (2004) ERß sensitizes breast cancer cells to retinoic acid: evidence of transcriptional crosstalk. Mol Cancer Res 2:523-531

122. Wang B, Yang Q, Harris CL et al (2016) Nutrigenomic regulation of adipose tissue development - role of retinoic acid: a review. Meat Sci 120:100-106. https://doi.org/10.1016/j.meatsci.2016.04.003

123. Schierle S, Merk D (2019) Therapeutic modulation of retinoid X receptors-SAR and therapeutic potential of RXR ligands and recent patents. Expert Opin Ther Pat 29:605-621. https://doi.org/10.1080/13543 776.2019 .1643322

124. Burt Wolbach S, Howe PR (1925) Tissue changes following deprivation of fat-soluble A vitamin. J Exp Med 42:753-778. https://doi.org/10.1084/ jem.42.6.753

125. Hale F (1933) Pigs born without eye balls. J Hered 24:105-106. https:// doi.org/10.1093/oxfordjournals.jhered.a103720 
126. Green HN, Mellanby E (1928) Vitamin a as an anti-infective agent. BMJ 2:691-696. https://doi.org/10.1136/bmj.2.3537.691

127. Wilson JG, Roth CB, Warkany J (1953) An analysis of the syndrome of malformations induced by maternal vitamin A deficiency. Effects of restoration of vitamin a at various times during gestation. Am J Anatomy 92:189-217. https://doi.org/10.1002/aja.1000920202

128. Thampson JN, Howell JM, Pitt GAJ, McLaughlin Cl (1969) The biological activity of retinoic acid in the domestic fowl and the effects of vitamin A deficiency on the chick embryo. Br J Nutr 23:471-490. https://doi. org/10.1079/bjn19690056

129. Kalter H, Warkany J (1959) Experimental production of congenital malformations in mammals by metabolic procedure. Physiol Rev 39:69-115. https://doi.org/10.1152/physrev.1959.39.1.69

130. Kochhar DM (1973) Limb development in mouse embryos. I. Analysis of teratogenic effects of retinoic acid. Teratology 7:289-298. https://doi. org/10.1002/tera. 1420070310

131. WHO (2009) Global prevalence of vitamin A deficiency in populations at risk 1995-2005 WHO Global Database on Vitamin A Deficiency. World Health Organization, Geneva

132. WHO (2013) Micronutrient deficiencies - Vitamin A deficiency. In: WHO. https://www.who.int/nutrition/topics/vad/en/. Accessed 24 Mar 2020

133. Sommer A, Djunaedi E, Loeden AA et al (1986) Impact of vitamin A supplementation on childhood mortality. A randomised controlled community trial. Lancet 1:1169-1173. https://doi.org/10.1016/S0140 $-6736(86) 91157-8$

134. Niederreither K, Dollé P (2008) Retinoic acid in development: towards an integrated view. Nat Rev Genet 9:541-553

135. Brent GA (2012) Mechanisms of thyroid hormone action. J Clin Investig 122:3035-3043. https://doi.org/10.1172/JCl60047

136. Kogai T, Liu Y-Y, Richter LL et al (2010) Retinoic acid induces expression of the thyroid hormone transporter, monocarboxylate transporter 8 (Mct8). J Biol Chem 285:27279-27288. https://doi.org/10.1074/jbc. M110.123158

137. Duester $G$ (2008) Retinoic acid synthesis and signaling during early organogenesis. Cell 134:921-931. https://doi.org/10.1016/j. cell.2008.09.002

138. D'Aniello E, Waxman JS, D'Aniello E, Waxman JS (2015) Input overload: contributions of retinoic acid signaling feedback mechanisms to heart development and teratogenesis. Dev Dyn 244:513-523. https://doi. org/10.1002/dvdy.24232

139. Antipatis C, Ashworth CJ, Grant G et al (1998) Effects of maternal vitamin A status on fetal heart and lung: changes in expression of key developmental genes. Am J Physiol Lung Cell Mol Physiol. https://doi. org/10.1152/ajplung.1998.275.6.11184

140. Stefanovic S, Zaffran S (2017) Mechanisms of retinoic acid signaling during cardiogenesis. Mech Dev 143:9-19. https://doi.org/10.1016/j. mod.2016.12.002

141. Malpel S, Mendelsohn C, Cardoso WV (2000) Regulation of retinoic acid signaling during lung morphogenesis. Development 127:3057-3067

142. Biesalski HK, Nohr D (2003) Importance of vitamin-A for lung function and development. Mol Aspects Med 24:431-440. https://doi. org/10.1016/50098-2997(03)00039-6

143. Maden M, Hind M (2004) Retinoic acid in alveolar development, maintenance and regeneration. In: Philosophical Transactions of the Royal Society B: Biological Sciences. Roy Soc 359:799-808

144. Sternberg RM, Gooding MP, Hotchkiss AK, LeBlanc GA (2010) Environmental-endocrine control of reproductive maturation in gastropods: implications for the mechanism of tributyltin-induced imposex in prosobranchs. Ecotoxicology 19:4-23

145. Lufkin T, Lohnes D, Mark M et al (1993) High postnatal lethality and testis degeneration in retinoic acid receptor a mutant mice. Proc Natl Acad Sci USA 90:7225-7229. https://doi.org/10.1073/pnas.90.15.7225

146. Spiller CM, Bowles J (2015) Sex determination in mammalian germ cells. Asian J Androl 17:427-432. https://doi.org/10.4103/1008-682X.150037

147. Kastner P, Mark M, Leid M et al (1996) Abnormal spermatogenesis in RXRß mutant mice. Genes Dev 10:80-92. https://doi.org/10.1101/ gad.10.1.80

148. Kam RKT, Deng Y, Chen Y, Zhao H (2012) Retinoic acid synthesis and functions in early embryonic development. Cell and Bioscience 2:11 https://doi.org/10.1186/2045-3701-2-11
149. LiY, Cheng CN, Verdun VA, Wingert RA (2014) Zebrafish nephrogenesis is regulated by interactions between retinoic acid, mecom, and Notch signaling. Develop Biol 386:111-122. https://doi.org/10.1016/j.ydbio .2013.11.021

150. Denisenko-Nehrbass NI, Mello CV (2001) Molecular targets of disulfiram action on song maturation in zebra finches. Mol Brain Res 87:246-250. https://doi.org/10.1016/S0169-328X(01)00002-X

151. Chiang MY, Misner D, Kempermann G et al (1998) An essential role for retinoid receptors RAR $\beta$ and RXRY in long-term potentiation and depression. Neuron 21:1353-1361. https://doi.org/10.1016/S0896 $-6273(00) 80654-6$

152. Cocco S, Diaz G, Stancampiano R et al (2002) Vitamin A deficiency produces spatial learning and memory impairment in rats. Neuroscience 115:475-482. https://doi.org/10.1016/S0306-4522(02)00423-2

153. Etchamendy N, Enderlin V, Marighetto A et al (2003) Vitamin A deficiency and relational memory deficit in adult mice: relationships with changes in brain retinoid signalling. Behav Brain Res 145:37-49. https:// doi.org/10.1016/S0166-4328(03)00099-8

154. Corcoran J, Maden M (1999) Nerve growth factor acts via retinoic acid synthesis to stimulate neurite outgrowth. Nat Neurosci 2:307-308

155. Zhelyaznik N, Schrage K, McCaffery P, Mey J (2003) Activation of retinoic acid signalling after sciatic nerve injury: up-regulation of cellular retinoid binding proteins. Eur J Neurosci 18:1033-1040. https://doi.org/10. 1046/j.1460-9568.2003.02834.x

156. Zhelyaznik N, Mey J (2006) Regulation of retinoic acid receptors a, $\beta$ and retinoid $X$ receptor $a$ after sciatic nerve injury. Neuroscience 141:1761-1774. https://doi.org/10.1016/j.neuroscience.2006.05.021

157. Ross AC (2012) Vitamin A and retinoic acid in T cell-related immunity. Am J Clin Nutr 96:1166S-1172S. https://doi.org/10.3945/ajcn.112.03463 7

158. Mey J, Schrage K, Wessels I, Vollpracht-Crijns I (2007) Effects of inflammatory cytokines IL-1 $\beta, \mathrm{IL}-6$, and TNFa on the intracellular localization of retinoid receptors in Schwann cells. GLIA 55:152-164. https://doi. org/10.1002/glia.20444

159. Wendland K, Niss K, Kotarsky K et al (2018) Retinoic acid signaling in thymic epithelial cells regulates thymopoiesis. J Immunol 201:524-532. https://doi.org/10.4049/jimmunol.1800418

160. Underwood BA (1984) Vitamin A in animal and human nutrition. In: The Retinoids. Elsevier, pp 281-392

161. Topletz AR, Tripathy S, Foti RS et al (2015) Induction of CYP26A1 by metabolites of retinoic acid: evidence that CYP26A1 is an important enzyme in the elimination of active retinoids. Mol Pharmacol 87:430-441. https://doi.org/10.1124/mol.114.096784

162. Samarut $E$, Fraher $D$, Laudet $V$, Gibert $Y$ (2015) ZebRA: an overview of retinoic acid signaling during zebrafish development. Biochimica et Biophysica Acta - Gene Regulatory Mechanisms 1849:73-83

163. Molotkova N, Molotkov A, Duester G (2007) Role of retinoic acid during forebrain development begins late when Raldh3 generates retinoic acid in the ventral subventricular zone. Develop Biol 303:601-610. https ://doi.org/10.1016/j.ydbio.2006.11.035

164 Rhinn M, Schuhbaur B, Niederreither K, Dollé P (2011) Involvement of retinol dehydrogenase 10 in embryonic patterning and rescue of its loss of function by maternal retinaldehyde treatment. Proc Natl Acad Sci USA 108:16687-16692. https://doi.org/10.1073/pnas.1103877108

165. Tonk ECM, Pennings JLA, Piersma AH (2015) An adverse outcome pathway framework for neural tube and axial defects mediated by modulation of retinoic acid homeostasis. Reprod Toxicol 55:104-113. https://doi.org/10.1016/j.reprotox.2014.10.008

166. Robinson JF (2014) Retinoids and developmental neurotoxicity in vivo and in vitro. Available via OECD. https://www.oecd.org/chemicalsafety/ testing/Retinoid CNSv2.pdf. Accessed 27 Apr 2020.

167. Piersma AH, Hessel EV, Staal YC (2017) Retinoic acid in developmental toxicology: teratogen, morphogen and biomarker. Reprod Toxicol 72:53-61. https://doi.org/10.1016/j.jeprotox.2017.05.014

168. Chen Y, Reese DH (2016) Disruption of retinol (vitamin A) signaling by phthalate esters: SAR and mechanism studies. PLoS ONE 11:e0161167. https://doi.org/10.1371/journal.pone.0161167

169. Ellis-Hutchings RG, Cherr GN, Hanna LA, Keen CL (2009) The effects of marginal maternal vitamin A status on penta-brominated diphenyl ether mixture-induced alterations in maternal and conceptal vitamin A 
and fetal development in the Sprague Dawley rat. Birth Defects Res B 86:48-57. https://doi.org/10.1002/bdrb.20181

170. Haggard DE, Das SR, Tanguay RL (2017) Comparative toxicogenomic responses to the flame retardant mITP in developing Zebrafish. Chem Res Toxicol 30:508-515. https://doi.org/10.1021/acs.chemrestox.6b004 23

171. ENDpoiNTs (2019) Novel Testing Strategies for Endocrine Disruptors in the Context of Developmental NeuroToxicity. ENDpoiNTs Project. https ://cordis.europa.eu/project/id/825759. Accessed 2 Jun 2020

172. van Neerven S, Kampmann E, Mey J (2008) RAR/RXR and PPAR/RXR signaling in neurological and psychiatric diseases. Prog Neurobiol 85:433-451

173. Lane MA, Bailey SJ (2005) Role of retinoid signalling in the adult brain Prog Neurobiol 75:275-293

174. Wondolowski J, Dickman D (2013) Emerging links between homeostatic synaptic plasticity and neurological disease. Front Cell Neurosci 7:223

175. Walters BJ, Josselyn SA (2019) Retinoic acid receptor plays both sides of homeostatic plasticity. Proc Natl Acad Sci USA 116:6528-6530

176. Hsu YT, Li J, Wu D et al (2019) Synaptic retinoic acid receptor signaling mediates mTOR-dependent metaplasticity that controls hippocampal learning. Proc Natl Acad Sci USA 116:7113-7122

177. Bremner JD, McCaffery P (2008) The neurobiology of retinoic acid in affective disorders. Prog Neuropsychopharmacol Biol Psychiatry 32:315-331. https://doi.org/10.1016/j.pnpbp.2007.07.001

178. Goodman AB (2006) Retinoid receptors, transporters, and metabolizers as therapeutic targets in late onset Alzheimer disease. J Cell Physiol 209:598-603

179. Alzheimer's Association (2020) 2020 Alzheimer's disease facts and figures. Alzheimer's \& Dementia 16:391-460. https://doi.org/10.1002/ alz.12068

180. Xu J, Murphy SL, Kochanek KD, Arias E (2020) Mortality in the United States, 2018. NCHS Data Brief No 355

181. Carroll WM (2019) The global burden of neurological disorders. Lancet Neurol 18:418-419

182. Nichols E, Szoeke CEl, Vollset SE et al (2019) Global, regional, and national burden of Alzheimer's disease and other dementias, 1990 2016: a systematic analysis for the Global Burden of Disease Study 2016. Lancet Neurol 18:88-106. https://doi.org/10.1016/S1474-4422(18)30403 $-4$

183. Yegambaram M, Manivannan B, Beach T, Halden R (2015) Role of environmental contaminants in the etiology of Alzheimer's Disease: a review. Curr Alzheimer Res 12:116-146. https://doi.org/10.2174/15672 05012666150204121719

184. Gauthier E, Fortier I, Courchesne F et al (2001) Environmental pesticide exposure as a risk factor for Alzheimer's disease: a case-control study. Environ Res 86:37-45. https://doi.org/10.1006/enrs.2001.4254

185. Killin LOJ, Starr JM, Shiue IJ, Russ TC (2016) Environmental risk factors for dementia: a systematic review. BMC Geriatrics 16:1-28. https://doi. org/10.1186/s12877-016-0342-y

186. Adams J (2010) The neurobehavioral teratology of retinoids: a 50-year history. Birth Defects Res A 88:895-905. https://doi.org/10.1002/ bdra.20721

187. Ferguson SA, Cisneros FJ, Gough BJ, Ali SF (2005) Four weeks of oral isotretinoin treatment causes few signs of general toxicity in male and female Sprague-Dawley rats. Food Chem Toxicol 43:1289-1296. https:// doi.org/10.1016/j.fct.2005.02.016

188. Olson CR, Mello CV (2010) Significance of vitamin A to brain function, behavior and learning. Mol Nutr Food Res 54:489-495

189. Galván A (2010) Neural plasticity of development and learning. Hum Brain Mapp 31:879-890. https://doi.org/10.1002/hbm.21029

190. McCaffery P, Zhang J, Crandall JE (2006) Retinoic acid signaling and function in the adult hippocampus. J Neurobiol 66:780-791

191. Nomoto M, Takeda Y, Uchida S et al (2012) Dysfunction of the RAR/RXR signaling pathway in the forebrain impairs hippocampal memory and synaptic plasticity. Mol Brain 5:8. https://doi.org/10.1186/1756-6606-5-8

192. Crandall J, Sakai Y, Zhang J et al (2004) 13-cis-retinoic acid suppresses hippocampal cell division and hippocampal-dependent learning in mice. Proc Natl Acad Sci USA 101:5111-5116. https://doi.org/10.1073/ pnas.0306336101
193. Wagner E, Luo T, Dräger UC (2002a) Retinoic acid synthesis in the postnatal mouse brain marks distinct developmental stages and functional systems. Cerebral cortex (New York, NY : 1991) 12:1244-53. https://doi. org/10.1093/cercor/12.12.1244

194. Fragoso YD, Shearer KD, Sementilli A et al (2012) High expression of retinoic acid receptors and synthetic enzymes in the human hippocampus. Brain Struct Functon 217:473-483. https://doi.org/10.1007/s0042 9-011-0359-0

195. Aoto J, Nam Cl, Poon MM et al (2008) Synaptic signaling by all-trans retinoic acid in homeostatic synaptic plasticity. Neuron 60:308-320. https://doi.org/10.1016/j.neuron.2008.08.012

196. Chen N, Napoli JL (2008) All- trans -retinoic acid stimulates translation and induces spine formation in hippocampal neurons through a membrane-associated RARa. FASEB J 22:236-245. https://doi.org/10.1096/ f.07-8739com

197. Rothwell CM, Spencer GE (2014) Retinoid signaling is necessary for, and promotes long-term memory formation following operant conditioning. Neurobiol Learn Mem 114:127-140. https://doi.org/10.1016/j. nlm.2014.05.010

198. Denisenko-Nehrbass NI, Jarvis E, Scharff C et al (2000) Site-specific retinoic acid production in the brain of adult songbirds. Neuron 27:359-370. https://doi.org/10.1016/S0896-6273(00)00043-X

199. Wood WE, Olson CR, Lovell PV, Mello CV (2008) Dietary retinoic acid affects song maturation and gene expression in the song system of the zebra finch. Develop Neurobiol 68:1213-1224. https://doi.org/10.1002/ dneu.20642

200. Negwer M, Schubert D (2017) Talking convergence: growing evidence links FOXP2 and retinoic acid in shaping speech-related motor circuitry. Front Neurosci 11:19. https://doi.org/10.3389/fnins.2017.00019

201. Enderlin V, Alfos S, Pallet V et al (1997) Aging decreases the abundance of retinoic acid (RAR) and triiodothyronine (TR) nuclear receptor mRNA in rat brain: effect of the administration of retinoids. FEBS Lett 412:629-632. https://doi.org/10.1016/50014-5793(97)00845-4

202. Khatib T, Chisholm DR, Whiting A et al (2020) Decay in retinoic acid signaling in varied models of Alzheimer's Disease and in vitro test of novel retinoic acid receptor ligands (RAR-Ms) to regulate protective genes. J Alzheimer's Dis 73:935-954. https://doi.org/10.3233/JAD-19093

203. Etchamendy N, Enderlin V, Marighetto A et al (2001) Alleviation of a selective age-related relational memory deficit in mice by pharmacologically induced normalization of brain retinoid signaling. J Neurosci 21:6423-6429. https://doi.org/10.1523/jneurosci.21-16-06423.2001

204. Mayeux R, Stern Y (2012) Epidemiology of Alzheimer disease. Cold Spring Harbor Perspect Med 2:a006239. https://doi.org/10.1101/cshpe rspect.a006239

205. Sahin M, Karauzum SB, Perry G et al (2005) Retinoic acid isomers protect hippocampal neurons from amyloid-beta induced neurodegeneration. Neurotox Res 7:243-250. https://doi.org/10.1007/bf03036453

206. Ono K, Yoshiike Y, Takashima A et al (2004) Vitamin A exhibits potent antiamyloidogenic and fibril-destabilizing effects in vitro. Exp Neurol 189:380-392. https://doi.org/10.1016/j.expneurol.2004.05.035

207. Lahiri DK, Nall C (1995) Promoter activity of the gene encoding the beta-amyloid precursor protein is up-regulated by growth factors, phorbol ester, retinoic acid and interleukin-1. Brain Res Mol Brain Res 32:233-240. https://doi.org/10.1016/0169-328x(95)00078-7

208. Steardo L, Signorile A, Scuderi C, Carratù MR (2016) How could retinoids fit into Alzheimer's therapy? Drugs Fut 41:15-23

209. Fukasawa H, Nakagomi M, Yamagata N et al (2012) Tamibarotene: a candidate retinoid drug for Alzheimer's disease. Biol Pharm Bull 35:1206-1212. https://doi.org/10.1248/bpb.b12-00314

210. ClinicalTrials.gov (2011) Efficacy and Safety of Tamibarotene (OAM80) for Alzheimer's Disease. https://clinicaltrials.gov/ct2/show/study/NCT01 120002.Accessed 13 May 2020

211. Corcoran JPT, Po LS, Maden M (2004) Disruption of the retinoid signalling pathway causes a deposition of amyloid $\beta$ in the adult rat brain. Eur J Neurosci 20:896-902. https://doi.org/10.1111/j.1460-9568.2004.03563 $x$

212. Colas J, Chessel N, Ouared A et al (2020) Neuroprotection against amyloid- $\beta$-induced DNA double-strand breaks is mediated by multiple retinoic acid-dependent pathways. Neural Plasticity. ID 9369815. https //doi.org/10.1155/2020/9369815 
213. Gruz-Gibelli E, Chessel N, Allioux C et al (2016) The Vitamin A derivative all-trans retinoic acid repairs amyloid- $\beta$-induced double-strand breaks in neural cells and in the murine neocortex. Neural Plasticity 2016:11. https://doi.org/10.1155/2016/3707406

214. Manzine PR, Ettcheto M, Cano A et al (2019) ADAM10 in Alzheimer's disease: pharmacological modulation by natural compounds and its role as a peripheral marker. Biomed Pharmacother 113:108661

215. Goncalves MB, Clarke E, Hobbs $C$ et al (2013) Amyloid $\beta$ inhibits retinoic acid synthesis exacerbating Alzheimer disease pathology which can be attenuated by an retinoic acid receptor a agonist. Eur J Neurosci 37:1182-1192. https://doi.org/10.1111/ejn.12142

216. Tippmann F, Hundt J, Schneider A et al (2009) Up-regulation of the a-secretase ADAM10 by retinoic acid receptors and acitretin. FASEB J 23:1643-1654. https://doi.org/10.1096/fj.08-121392

217. Endres K, Fahrenholz F, Lotz J et al (2014) Increased CSF APPs-a levels in patients with Alzheimer disease treated with acitretin. Neurology 83:1930-1935. https://doi.org/10.1212/WNL.0000000000001017

218. Jarvis Cl, Goncalves MB, Clarke E et al (2010) Retinoic acid receptor-a signalling antagonizes both intracellular and extracellular amyloid- $\beta$ production and prevents neuronal cell death caused by amyloid- $\beta$. Eur J Neurosci 32:1246-1255. https://doi.org/10.111 1/j.1460-9568.2010.07426.x

219. Cummings JL, Zhong K, Kinney JW et al (2016) Double-blind, placebocontrolled, proof-of-concept trial of bexarotene in moderate Alzheimer's disease. Alzheimer's Res Ther 8:1-9. https://doi.org/10.1186/s1319 5-016-0173-2

220. Nolen GA (1986) The effects of prenatal retinoic acid on the viability and behavior of the offspring. Neurobehav Toxicol Teratol 8:643-654

221. US FDA (2005) Isotretinoin (marketed as Accutane) Capsule Information - FDA. https://www.fda.gov/drugs/postmarket-drug-safety-informatio n-patients-and-providers/isotretinoin-marketed-accutane-capsule-infor mation. Accessed 13 May 2020

222. EMA (2018) Updated measures for pregnancy prevention during retinoid use. Warning on possible risk of neuropsychiatric disorders also to be included for oral retinoids. EMA/261767/2018. Committee for Medicinal Products for Human Use (CHMP) EMEA/H/A-3

223. Marqueling AL, Zane LT (2005) Depression and suicidal behavior in acne patients treated with isotretinoin: a systematic review. Semin Cutan Med Surg 24:92-102. https://doi.org/10.1016/j.sder.2005.04.003

224. Strahan JE, Raimer S (2006) Isotretinoin and the controversy of psychiatric adverse effects. Int J Dermatol 45:789-799. https://doi.org/10.111 1/j.1365-4632.2006.02660.x

225. Bremner JD, Shearer KD, McCaffery PJ (2012) Retinoic acid and affective disorders. J Clin Psychiatry 73:37-50. https://doi.org/10.4088/JCP.10r05 993

226. Krężel W, Ghyselinck N, Samad TA et al (1998) Impaired locomotion and dopamine signaling in retinoid receptor mutant mice. Science 279:863-867. https://doi.org/10.1126/science.279.5352.863

227. Samad TA, Krężel W, Chambon P, Borrelli E (1997) Regulation of dopaminergic pathways by retinoids: activation of the $D 2$ receptor promoter by members of the retinoic acid receptor-retinoid $X$ receptor family. Proc Natl Acad Sci USA 94:14349-14354. https://doi.org/10.1073/ pnas.94.26.14349

228. Zetterström RH, Solomin L, Jansson L et al (1997) Dopamine neuron agenesis in Nurr1-deficient mice. Science 276:248-250. https://doi. org/10.1126/science.276.5310.248

229. Krzyzosiak A, Szyszka-Niagolov M, Wietrzych M et al (2010) Retinoid X receptor gamma control of affective behaviors involves dopaminergic signaling in mice. Neuron 66:908-920. https://doi.org/10.1016/j.neuro n.2010.05.004

230. Valdenaire O, Maus-Moatti M, Vincent J-D et al (2002) Retinoic acid regulates the developmental expression of dopamine D2 receptor in rat striatal primary cultures. J Neurochem 71:929-936. https://doi.org/1 0.1046/j.1471-4159.1998.71030929.x

231. Wang HF, Liu FC (2005) Regulation of multiple dopamine signal transduction molecules by retinoids in the developing striatum. Neuroscience 134:97-105. https://doi.org/10.1016/j.neuroscience.2005.04.008

232. O'Reilly KC, Shumake J, Gonzalez-Lima F et al (2006) Chronic administration of 13-cis-retinoic acid increases depression-related behavior in mice. Neuropsychopharmacology 31:1919-1927. https://doi. org/10.1038/sj.npp.1300998
233. O'Reilly K, Bailey SJ, Lane MA (2008) Retinoid-mediated regulation of mood: possible cellular mechanisms. Exp Biol Med 233:251-258. https ://doi.org/10.3181/0706-MR-158

234. Ferguson SA, Cisneros FJ, Gough B et al (2005) Chronic oral treatment with 13-cis-retinoic acid (isotretinoin) or all-trans-retinoic acid does not alter depression-like behaviors in rats. Toxicol Sci 87:451-459. https:// doi.org/10.1093/toxsci/kfi262

235. Qi XR, Zhao J, Liu J et al (2015) Abnormal retinoid and TrkB signaling in the prefrontal cortex in mood disorders. Cereb Cortex 25:75-83. https:// doi.org/10.1093/cercor/bht203

236. Tschudi-Monnet F, FitzGerald R (2019) AOP 12: Chronic binding of antagonist to $\mathrm{N}$-methyl-D-aspartate receptors (NMDARs) during brain development leads to neurodegeneration with impairment in learning and memory in aging. https://aopwiki.org/aops/12. Accessed 7 Jul 2020

237. Sachana M, Munn S, Bal-Price A (2019) AOP 13: Chronic binding of antagonist to $\mathrm{N}$-methyl-D-aspartate receptors (NMDARs) during brain development induces impairment of learning and memory abilities. https://aopwiki.org/aops/13. Accessed 7 Jul 2020

238. Rolaki A, Pistollato F, Munn S, Bal-Price A (2019) AOP 54: Inhibition of $\mathrm{Na}+/$ - - symporter (NIS) leads to learning and memory impairment. https://aopwiki.org/aops/54. Accessed 7 Jul 2020

239. Jablensky A (2000) Epidemiology of schizophrenia: the global burden of disease and disability. Eur Arch Psychiatry Clin Neurosci 250:274-285. https://doi.org/10.1007/s004060070002

240. Ripke S, Neale BM, Corvin A et al (2014) Biological insights from 108 schizophrenia-associated genetic loci. Nature 511:421-427. https://doi. org/10.1038/nature13595

241. Stilo SA, Murray RM (2019) Non-genetic factors in schizophrenia. Curr Psychiatry Rep 21:100. https://doi.org/10.1007/s11920-019-1091-3

242. Laruelle M, Abi-Dargham A (1999) Dopamine as the wind of the psychotic fire: New evidence from brain imaging studies. J Psychopharmacol 13:358-371

243. Coyle JT (2006) Glutamate and schizophrenia: beyond the dopamine hypothesis. Cell Mol Neurobiol 26:365-384

244. Fernandez-Espejo E, Viveros MP, Núñez L et al (2009) Role of cannabis and endocannabinoids in the genesis of schizophrenia. Psychopharmacology 206:531-549

245. Radhakrishnan R, Kaser M, Guloksuz S (2017) The Link between the Immune System, Environment, and Psychosis. Schizophr Bull 43:693-697. https://doi.org/10.1093/schbul/sbx057

246. Goodman AB (1998) Three independent lines of evidence suggest retinoids as causal to schizophrenia. Proc Natl Acad Sci USA 95:7240-7244

247. Mistry M, Gillis J, Pavlidis P (2013) Genome-wide expression profiling of schizophrenia using a large combined cohort. Mol Psychiatry 18:215-225. https://doi.org/10.1038/mp.2011.172

248. Larsen R, Proue A, Scott EP, et al (2019) The thalamus regulates retinoic acid signaling and development of parvalbumin interneurons in postnatal mouse prefrontal cortex. eNeuro. 6:1-17. https://doi.org/10.1523/ ENEURO.0018-19.2019

249. Sehnal L, Procházková T, Smutná M et al (2019) Widespread occurrence of retinoids in water bodies associated with cyanobacterial blooms dominated by diverse species. Water Res 156:136-147. https://doi. org/10.1016/j.watres.2019.03.009

250. Javůrek J, Sychrová E, Smutná M et al (2015) Retinoid compounds associated with water blooms dominated by Microcystis species. Harmful Algae 47:116-125. https://doi.org/10.1016/j.hal.2015.06.006

251. Wu X, Jiang J, Wan Y et al (2012) Cyanobacteria blooms produce teratogenic retinoic acids. Proc Natl Acad Sci 109:9477-9482. https://doi. org/10.1073/pnas.1200062109

252. Wu X, Jiang J, Hu J (2013) Determination and Occurrence of Retinoids in a Eutrophic Lake (Taihu Lake, China): cyanobacteria Blooms Produce Teratogenic Retinal. Environ Sci Technol 47:807-814. https://doi. org/10.1021/es303582u

253. Yeung KWY, Zhou G-J, Hilscherová K et al (2020) Current understanding of potential ecological risks of retinoic acids and their metabolites in aquatic environments. Environ Int 136:105464. https://doi. org/10.1016/j.envint.2020.105464

254. Vandenberg LN, Hunt PA, Gore AC (2019) Endocrine disruptors and the future of toxicology testing-lessons from CLARITY-BPA. Nat Rev Endocrinol 15:366-374 
255. Wilson VS, LeBlanc GA, Kullman S et al (2016) Where do we go from here: challenges and the future of endocrine disrupting compound screening and testing. PeerJ Preprints 4:e2605v1. https://doi. org/10.7287/peerj.preprints.2605v1

256. Huang R, Sakamuru S, Martin MT et al (2014) Profiling of the Tox21 $10 \mathrm{~K}$ compound library for agonists and antagonists of the estrogen receptor alpha signaling pathway. Scientific Reports 4:1-9. https://doi. org/10.1038/srep05664

257. Huang R, Xia M, Cho M-H et al (2011) Chemical genomics profiling of environmental chemical modulation of human nuclear receptors. Environ Health Perspect 119:1142-1148. https://doi.org/10.1289/ehp.10029 52

258. Knudsen TB, Houck KA, Sipes NS et al (2011) Activity profiles of 309 ToxCast $^{\text {TM }}$ chemicals evaluated across 292 biochemical targets. Toxicology 282:1-15. https://doi.org/10.1016/j.tox.2010.12.010

259. Martin MT, Dix DJ, Judson RS et al (2010) Impact of environmental chemicals on key transcription regulators and correlation to toxicity end points within EPA's toxcast program. Chem Res Toxicol 23:578-590. https://doi.org/10.1021/tx900325g

260. EC (2018) Proposal for a Directive of the European Parliament and of the Council on the quality of water intended for human consumption (recast). COM(2017) 753 final. https://eur-lex.europa.eu/legal-content/ en/TXT/?uri=CELEX\%3A52018DC0257

261. Huisman J, Codd GA, Paerl HW et al (2018) Cyanobacterial blooms. Nat Rev Microbiol 16:471-483. https://doi.org/10.1038/s41579-018-0040-1

262. Verspagen JMH, Van de Waal DB, Finke JF et al (2014) Rising CO2 levels will intensify phytoplankton blooms in eutrophic and hypertrophic lakes. PLoS ONE 9:e104325. https://doi.org/10.1371/journal.pone.01043 25

263. Jankowiak J, Hattenrath-Lehmann T, Kramer BJ et al (2019) Deciphering the effects of nitrogen, phosphorus, and temperature on cyanobacterial bloom intensification, diversity, and toxicity in western Lake Erie. Limnol Oceanogr 64:1347-1370. https://doi.org/10.1002/Ino.11120

264. Vinçon-Leite B, Casenave C (2019) Modelling eutrophication in lake ecosystems: a review. Sci Total Environ 651:2985-3001. https://doi. org/10.1016/j.scitotenv.2018.09.320

265. Havens KE, Ji G, Beaver JR et al (2019) Dynamics of cyanobacteria blooms are linked to the hydrology of shallow Florida lakes and provide insight into possible impacts of climate change. Hydrobiologia 829:43-59. https://doi.org/10.1007/s10750-017-3425-7

266. Meier HEM, Eilola K, Almroth-Rosell E et al (2019) Disentangling the impact of nutrient load and climate changes on Baltic Sea hypoxia and eutrophication since 1850. Clim Dyn 53:1-22. https://doi.org/10.1007/ s00382-018-4296-y

267. Heathwaite AL, Dils RM (2000) Characterising phosphorus loss in surface and subsurface hydrological pathways. Sci Total Environ 251-252:523-538. https://doi.org/10.1016/50048-9697(00)00393-4

268. Jeppesen E, Kronvang B, Meerhoff M et al (2009) Climate change effects on runoff, catchment phosphorus loading and lake ecological state, and potential adaptations. J Environ Qual 38:1930-1941. https://doi. org/10.2134/jeq2008.0113

269. Buratti FM, Manganelli M, Vichi S et al (2017) Cyanotoxins: producing organisms, occurrence, toxicity, mechanism of action and human health toxicological risk evaluation. Arch Toxicol 91:1049-1130. https:// doi.org/10.1007/s00204-016-1913-6

270. Chorus I, Welker M (Eds) (2021) Toxic cyanobacteria in water: A Guide to Their Public Health Consequences, Monitoring and Management, 2nd edn. CRC Press, London. https://doi.org/10.1201/9781003081449

271. Wu X, Hu J, Jia A et al (2010) Determination and occurrence of retinoic acids and their 4-oxo metabolites in Liaodong Bay, China, and its adjacent rivers. Environ Toxicol Chem 29:2491-2497. https://doi. org/10.1002/etc.322

272. Pipal M, Priebojova J, Koci T et al (2020) Field cyanobacterial blooms producing retinoid compounds cause teratogenicity in zebrafish embryos. Chemosphere 241:125061. https://doi.org/10.1016/j.chemo sphere.2019.125061

273. Smutná M, Priebojová J, Večerková J, Hilscherová K (2017) Retinoid-like compounds produced by phytoplankton affect embryonic development of Xenopus laevis. Ecotoxicol Environ Saf 138:32-38. https://doi. org/10.1016/j.ecoenv.2016.12.018
274. Jonas A, Scholz S, Fetter E et al (2015) Endocrine, teratogenic and neurotoxic effects of cyanobacteria detected by cellular in vitro and zebrafish embryos assays. Chemosphere 120:321-327. https://doi. org/10.1016/J.CHEMOSPHERE.2014.07.074

275. Jonas A, Buranova V, Scholz S et al (2014) Retinoid-like activity and teratogenic effects of cyanobacterial exudates. Aquat Toxicol 155:283-290. https://doi.org/10.1016/j.aquatox.2014.06.022

276. Kaya K, Shiraishi F, Uchida H, Sano T (2011) A novel retinoic acid analogue, 7-hydroxy retinoic acid, isolated from cyanobacteria. Biochim Biophys Acta Gen Subj 1810:414-419. https://doi.org/10.1016/j.bbage n.2010.11.009

277. Lambert WE, De Leenheer AP (1985) Demonstration of retinoic acid isomers in human urine under physiological conditions. Experientia 41:359-360. https://doi.org/10.1007/bf02004504

278. Nau H (1994) Retinoid teratogenesis: toxicokinetics and structurespecificity. In: Bolt HM, Hellman B, Dencker L (eds) Use of Mechanistic Information in Risk Assessment. Archives of Toxicology, Supplement 16, vol 16. Springer, Berlin, Heidelberg, pp 118-127

279. AGES (2007) Public Assessment Report - Scientific discussion: Cisderm 5 mg-capsules (Isotretinoin) AT/H/0165/01/DC

280. Zhen H, Wu X, Hu J et al (2009) Identification of retinoic acid receptor agonists in sewage treatment plants. Environ Sci Technol 43:6611-6616. https://doi.org/10.1021/es9000328

281. Sawada K, Inoue D, Wada Y et al (2012) Detection of retinoic acid receptor agonistic activity and identification of causative compounds in municipal wastewater treatment plants in Japan. Environ Toxicol Chem 31:307-315. https://doi.org/10.1002/etc.741

282. Inoue D, Sawada K, Wada Y et al (2013) Removal characteristics of retinoic acids and 4-oxo-retinoic acids in wastewater by activated sludge treatment. Water Sci Technol 67:2868-2874. https://doi.org/10.2166/ wst.2013.214

283. Zhou GJ, Li XY, Leung KMY (2019) Retinoids and oestrogenic endocrine disrupting chemicals in saline sewage treatment plants: removal efficiencies and ecological risks to marine organisms. Environ Int 127:103-113. https://doi.org/10.1016/j.envint.2019.03.030

284. Layton A, Dreno B, Gollnick H, Zouboulis C (2006) A review of the European Directive for prescribing systemic isotretinoin for acne vulgaris. J Eur Acad Dermatol Venereol 20:773-776. https://doi.org/10.111 1/j.1468-3083.2006.01671.x

285. de Almeida NR, Conda-Sheridan M (2019) A review of the molecular design and biological activities of RXR agonists. Med Res Rev 39:1372-1397

286. Bogen R, Lützow-Holm C, Lyche JL et al (2012) Risk assessment of vitamin A (retinol and retinyl esters) in cosmetics. Opinion of the panel on food additives, flavourings, processing aids, materials in contact with food and cosmetics of the norwegian scientific committee for food safety. VKM Report 1:74

287. EC (2019a) Database for information on cosmetic substances and ingredients (CosIng). https://ec.europa.eu/growth/tools-databases/cosing/ pdf/COSING_Annexll_v2.pdf. Accessed 2 Jun 2020

288. EC (2019b) Urban Waste Water Treatment Directive - Evaluation. https:/ ec.europa.eu/environment/water/water-urbanwaste/evaluation/index en.htm. Accessed 11 Feb 2020

289. EC (2019c) European Union Strategic Approach to Pharmaceuticals in the Environment - COM(2019)-128. Brussels

290. Brack W, Dulio V, Ågerstrand M et al (2017) Towards the review of the European Union Water Framework Directive: recommendations for more efficient assessment and management of chemical contamination in European surface water resources. Sci Total Environ 576:720-737. https://doi.org/10.1016/J.SCITOTENV.2016.10.104

291. Directive 2000/60/EC of the European Parliament and of the Council of 23 October 2000 establishing a framework for Community action in the field of water policy. Off J L 327:0001-0073. OJ L 327, 22.12.2000, p. 1-73. ELI: http://data.europa.eu/eli/dir/2000/60/oj

292. Council Directive 91/271/EEC of 21 May 1991 concerning urban wastewater treatment. OJ L 135, 30.5.1991, p. 40-52. ELI: http://data.europ a.eu/eli/dir/1991/271/oj

293. Council Directive $91 / 676 / \mathrm{EEC}$ of 12 December 1991 concerning the protection of waters against pollution caused by nitrates from agricultural sources. OJ L 375, 31.12.1991, p. 1-8. ELl: http://data.europa.eu/eli/ dir/1991/676/oj 
294. Directive (EU) 2020/2184 of the European Parliament and of the Council of 16 December 2020 on the quality of water intended for human consumption (recast). Document 32020L2184. OJ L 435, 23.12.2020, p. 1-62. ELI: http://data.europa.eu/eli/dir/2020/2184/oj

295. Hervás-Gámez C, Delgado-Ramos F (2019) Drought management planning policy: from Europe to Spain. Sustainability 11:1862. https://doi. org/10.3390/su11071862

296. Stein U, Özerol G, Tröltzsch J, et al (2016) European drought and water scarcity policies. In: Governance for Drought Resilience: Land and Water Drought Management in Europe. Springer International Publishing, pp 17-44

297. Posthuma L, Munthe J, van Gils J et al (2019) A holistic approach is key to protect water quality and monitor, assess and manage chemical pollution of European surface waters. Environ Sci Eur. https://doi. org/10.1186/s12302-019-0243-8

298. Kortenkamp A, Faust M, Backhaus T et al (2019) Mixture risks threaten water quality: the European Collaborative Project SOLUTIONS recommends changes to the WFD and better coordination across all pieces of European chemicals legislation to improve protection from exposure of the aquatic environment to improve protection from exposure of the aquatic environment to multiple pollutants. Environ Sci Eur 31:69. https ://doi.org/10.1186/s12302-019-0245-6

299. Jacobson JL, Jacobson SW (1996) Dose-response in perinatal exposure to polychlorinated biphenyls (PCBs): the Michigan and North Carolina cohort studies. Toxicol Ind Health 12:435-445. https://doi. org/10.1177/074823379601200315

300. Jacobson $\mathrm{J}$, Jacobson SW (1996) Intellectual impairment in children exposed to polychlorinated biphenyls in utero. N Engl J Med 335:783789. https://doi.org/10.1056/NEJM199609123351104

301. Urquhart EA, Schaeffer BA, Stumpf RP et al (2017) A method for examining temporal changes in cyanobacterial harmful algal bloom spatial extent using satellite remote sensing. Harmful Algae 67:144-152. https ://doi.org/10.1016/j.hal.2017.06.001

302. Junker T, Atorf C, Berkner S et al (2020) Development of a test method for transformation of veterinary pharmaceuticals and biocides in anaerobic liquid manure. Environmental Sciences Europe 32:1-21. https://doi.org/10.1186/s12302-020-00323-8

303. Saili KS, Antonijevic T, Zurlinden TJ et al (2020) Molecular characterization of a toxicological tipping point during human stem cell differentiation. Reprod Toxicol 91:1-13. https://doi.org/10.1016/j.repro tox.2019.10.001

304. Sewell F, Gellatly N, Beaumont M et al (2018) The future trajectory of adverse outcome pathways: a commentary. Arch Toxicol 92:1657-1661. https://doi.org/10.1007/s00204-018-2183-2

305. Teeguarden JG, Tan YM, Edwards SW et al (2016) Completing the link between exposure science and toxicology for improved environmental health decision making: the Aggregate Exposure Pathway framework. Environ Sci Technol 50:4579-4586. https://doi.org/10.1021/acs. est.5b05311

306. Hines DE, Edwards SW, Conolly RB, Jarabek AM (2018) A Case Study Application of the Aggregate Exposure Pathway (AEP) and Adverse Outcome Pathway (AOP) Frameworks to Facilitate the Integration of Human Health and Ecological End Points for Cumulative Risk Assessment (CRA). Environ Sci Technol 52:839-849. https://doi.org/10.1021/ acs.est.7b04940

307. Altenburger R, BrackW, Burgess RM et al (2019) Future water quality monitoring: improving the balance between exposure and toxicity assessments of real-world pollutant mixtures. Environ Sci Eur 31:12. https://doi.org/10.1186/s12302-019-0193-1

308. US EPA (2008) SAB Advisory on Aquatic Life Water Quality Criteria for Contaminants of Emerging Concern. EPA-SAB-09-007. 63

309. Dulio V, van Bavel B, Brorström-Lundén E et al (2018) Emerging pollutants in the EU: 10 years of NORMAN in support of environmental policies and regulations. Environ Sci Eur 30:1-13

310. UN (2015) The Sustainable Development Goals| International Cooperation and Development. https://ec.europa.eu/europeaid/policies/susta inable-development-goals_en. Accessed 22 Feb 2019

311. EC (2019d) The European Green Deall COM(2019) 640 final

312. Drakvik E, Altenburger R, Aoki $Y$ et al (2020) Statement on advancing the assessment of chemical mixtures and their risks for human health and the environment. Environ Int 134:105267. https://doi.org/10.1016/j. envint.2019.105267

313. Rydeen A, Voisin N, D'Aniello E et al (2015) Excessive feedback of Cyp26a1 promotes cell non-autonomous loss of retinoic acid signaling. Developmental Biology 405:47-55. https://doi.org/10.1016/j.ydbio .2015.06.008

314. Durston AJ (2019) What are the roles of retinoids, other morphogens, and Hox genes in setting up the vertebrate body axis? Genesis 57:e23296. https://doi.org/10.1002/dvg.23296

315. Maden M, Holder N (1992) Retinoic acid and development of the central nervous system. BioEssays 14:431-438. https://doi.org/10.1002/ bies.950140702

316. Kessel M, Gruss P (1991) Homeotic transformations of murine vertebrae and concomitant alteration of Hox codes induced by retinoic acid. Cell 67:89-104. https://doi.org/10.1016/0092-8674\%5b91\%5d90574-i

317. Dalfó D, Albalat R, Molotkov A et al (2002) Retinoic acid synthesis in the prevertebrate amphioxus involves retinol oxidation. Dev Genes Evol 212:388-393. https://doi.org/10.1007/s00427-002-0254-z

318. White RJ, Nie Q, Lander AD, Schilling TF (2007) Complex regulation of cyp26a1 creates a robust retinoic acid gradient in the zebrafish embryo. PLoS Biol 5:e304. https://doi.org/10.1371/journal.pbio.0050304

319. Spoorendonk KM, Peterson-Maduro J, Renn J et al (2008) Retinoic acid and Cyp26b1 are critical regulators of osteogenesis in the axial skeleton. Development 135:3765-3774. https://doi.org/10.1242/dev.02403

320. Bayha E, Jørgensen MC, Serup P, Grapin-Botton A (2009) Retinoic acid signaling organizes endodermal organ specification along the entire antero-posterior axis. PLoS ONE. 4:e5845. https://doi.org/10.1371/journ al.pone.0005845

321. Shimozono S, limura T, Kitaguchi T et al (2013) Visualization of an endogenous retinoic acid gradient across embryonic development. Nature 496:363-366. https://doi.org/10.1038/nature12037

322. André A, Ruivo R, Gesto M et al (2014) Retinoid metabolism in invertebrates: when evolution meets endocrine disruption. Gen Comp Endocrinol 208:134-145. https://doi.org/10.1016/j.ygcen.2014.08.005

323. Kawakami Y, Raya Á, Raya RM et al (2005) Retinoic acid signalling links left-right asymmetric patterning and bilaterally symmetric somitogenesis in the zebrafish embryo. Nature 435:165-171. https://doi. org/10.1038/nature03512

324. Vermot J, Pourquié $O$ (2005) Retinoic acid coordinates somitogenesis and left-right patterning in vertebrate embryos. Nature 435:215-220. https://doi.org/10.1038/nature03488

325. Vermot J, Llamas JG, Fraulob V et al (2005) Retinoic acid controls the bilateral symmetry of somite formation in the mouse embryo. Science 308:563-566. https://doi.org/10.1126/science.1108363

326. Menegola E, Broccia ML, Di Renzo F et al (2005) Craniofacial and axial skeletal defects induced by the fungicide triadimefon in the mouse. Birth Defects Res B 74:185-195. https://doi.org/10.1002/bdrb.20035

327. Del Corral RD, Olivera-Martinez I, Goriely A et al (2003) Opposing FGF and retinoid pathways control ventral neural pattern, neuronal differentiation, and segmentation during body axis extension. Neuron 40:65-79. https://doi.org/10.1016/S0896-6273(03)00565-8

328. Aulehla A, Pourquié $O$ (2010) Signaling gradients during paraxial mesoderm development. Cold Spring Harbor Perspect Biol 2:1049-1054. https://doi.org/10.1101/cshperspect.a000869

329. Pourquié O (2011) Vertebrate segmentation: from cyclic gene networks to scoliosis. Cell 145:650-663. https://doi.org/10.1016/j.cell.2011.05.011

330. Eyal-Giladi H (1954) Dynamic aspects of neural induction in amphibia. Arch Biol 65:179-259

331. Emoto $\mathrm{Y}$, Wada $\mathrm{H}$, Okamoto $\mathrm{H}$ et al (2005) Retinoic acid-metabolizing enzyme Cyp26a1 is essential for determining territories of hindbrain and spinal cord in zebrafish. Develop Biol 278:415-427. https://doi. org/10.1016/j.ydbio.2004.11.023

332. Del Corral RD, Storey KG (2004) Opposing FGF and retinoid pathways: a signalling switch that controls differentiation and patterning onset in the extending vertebrate body axis. BioEssays 26:857-869

333. Wilson V, Olivera-Martinez I, Storey KG (2009) Stem cells, signals and vertebrate body axis extension. Development 136:1591-1604. https:// doi.org/10.1242/dev.021246

334. Molotkov A, Molotkova N, Duester G (2005) Retinoic acid generated by Raldh2 in mesoderm is required for mouse dorsal endodermal 
pancreas development. Dev Dyn 232:950-957. https://doi.org/10.1002/ dvdy.20256

335. Novitch BG, Wichterle H, Jessell TM, Sockanathan S (2003) A requirement for retinoic acid-mediated transcriptional activation in ventral neural patterning and motor neuron specification. Neuron 40:81-95. https://doi.org/10.1016/j.neuron.2003.08.006

336. Wilson L, Gale E, Chambers D, Maden M (2004) Retinoic acid and the control of dorsoventral patterning in the avian spinal cord. Develop Biol 269:433-446. https://doi.org/10.1016/j.ydbio.2004.01.034

337. Ferdous J, Mukherjee R, Ahmed KTT, Ali DWW (2017) Retinoic acid prevents synaptic deficiencies induced by alcohol exposure during gastrulation in zebrafish embryos. NeuroToxicology 62:100-110. https ://doi.org/10.1016/j.neuro.2017.05.011

338. Emmett SD, West KP (2014) Gestational vitamin A deficiency: a novel cause of sensorineural hearing loss in the developing world? Med Hypotheses 82:6-10. https://doi.org/10.1016/j.mehy.2013.09.028

339. Frenz DA, Liu W, Cvekl A, et al (2010) Retinoid signaling in inner ear development: A "Goldilocks" phenomenon. American Journal of Medical Genetics, Part A 152 A:2947-2961

340. Morriss-Kay GM, Sokolova N (1996) Embryonic development and pattern formation. FASEB J 10:961-968. https://doi.org/10.1096/faseb j.10.9.8801178

341. White JC, Shankar VN, Highland M et al (1998) Defects in embryonic hindbrain development and fetal resorption resulting from vitamin $\mathrm{A}$ deficiency in the rat are prevented by feeding pharmacological levels of all-trans-retinoic acid. Proc Natl Acad Sci USA 95:13459-13464. https ://doi.org/10.1073/pnas.95.23.13459

342. Hollemann T, Chen Y, Grunz H, Pieler T (1998) Regionalized metabolic activity establishes boundaries of retinoic acid signalling. EMBO J 17:7361-7372. https://doi.org/10.1093/emboj/17.24.7361

343. Dupé $V$, Ghyselinck NB, Wendling O et al (1999) Key roles of retinoic acid receptors alpha and beta in the patterning of the caudal hindbrain, pharyngeal arches and otocyst in the mouse. Development 126:5051-5059

344. Gale E, Zile M, Maden M (1999) Hindbrain respecification in the retinoid-deficient quail. Mech Dev 89:43-54. https://doi.org/10.1016/ S0925-4773(99)00202-6

345. Yee KK, Rawson NE (2000) Retinoic acid enhances the rate of olfactory recovery after olfactory nerve transection. Brain Res Dev Brain Res 124:129-132. https://doi.org/10.1016/s0165-3806(00)00108-5

346. Chen Y, Pollet N, Niehrs C, Pieler T (2001) Increased XRALDH2 activity has a posteriorizing effect on the central nervous system of Xenopus embryos. Mech Dev 101:91-103. https://doi.org/10.1016/S0925 $-4773(00) 00558-X$

347. Abu-Abed S, Dollé P, Metzger D et al (2001) The retinoic acid-metabolizing enzyme, CYP26A1, is essential for normal hindbrain patterning, vertebral identity, and development of posterior structures. Genes Dev 15:226-240. https://doi.org/10.1101/gad.855001

348. Wagner E, Luo T, Dräger UC (2002) Retinoic acid synthesis in the postnatal mouse brain marks distinct developmental stages and functional systems. Cerebral cortex (New York, NY: 1991) 12:1244-53. https://doi. org/10.1093/cercor/12.12.1244

349. Linville A, Gumusaneli E, Chandraratna RASS, Schilling TF (2004) Independent roles for retinoic acid in segmentation and neuronal differentiation in the zebrafish hindbrain. Develop Biol 270:186-199. https ://doi.org/10.1016/j.ydbio.2004.02.022

350. Kiecker C, Lumsden A (2005) Compartments and their boundaries in vertebrate brain development. Nat Rev Neurosci 6:553-564

351. Maves L, Kimmel CB (2005) Dynamic and sequential patterning of the zebrafish posterior hindbrain by retinoic acid. Develop Biol 285:593605. https://doi.org/10.1016/j.ydbio.2005.07.015

352. Hägglund M, Berghard A, Strotmann J, Bohm S (2006) Retinoic acid receptor-dependent survival of olfactory sensory neurons in postnatal and adult mice. J Neurosci 26:3281-3291. https://doi.org/10.1523/ JNEUROSCI.4955-05.2006

353. Asson-Batres MA, Smith WB (2006) Localization of retinaldehyde dehydrogenases and retinoid binding proteins to sustentacular cells, glia, Bowman's gland cells, and stroma: potential sites of retinoic acid synthesis in the postnatal rat olfactory organ. J Comparative Neurol 496:149-171. https://doi.org/10.1002/cne.20904
354. Hernandez RE, Putzke AP, Myers JP et al (2007) Cyp26 enzymes generate the retinoic acid response pattern necessary for hindbrain development. Development 134:177-187. https://doi.org/10.1242/dev.02706

355. Maden M, Holder N (1991) The involvement of retinoic acid in the development of the vertebrate central nervous system. Development 113:87-94

356. Papalopulu N, Clarke JDD, Bradley L et al (1991) Retinoic acid causes abnormal development and segmental patterning of the anterior hindbrain in Xenopus embryos. Development 113:1145-1158

357. Holder N, Hill J (1991) Retinoic acid modifies development of the midbrain-hindbrain border and affects cranial ganglion formation in zebrafish embryos. Development 113:1159-1170

358. Maden M, Horton C, Graham A et al (1992) Domains of cellular retinoic acid-binding protein I (CRABP I) expression in the hindbrain and neural crest of the mouse embryo. Mech Dev 37:13-23. https://doi. org/10.1016/0925-4773(92)90011-8

359. Maden M, Gale E, Kostetskii I, Zile M (1996) Vitamin A-deficient quai embryos have half a hindbrain and other neural defects. Curr Biol 6:417-426. https://doi.org/10.1016/S0960-9822(02)00509-2

360. LaMantia AS, Colbert MC, Linney E (1993) Retinoic acid induction and regional differentiation prefigure olfactory pathway formation in the mammalian forebrain. Neuron 10:1035-1048. https://doi. org/10.1016/0896-6273(93)90052-S

361. Corwin JT, Cotanche DA (1988) Regeneration of sensory hair cells after acoustic trauma. Science 240:1772-1774. https://doi.org/10.1126/scien ce. 3381100

362. Lefebvre PP, Malgrange B, Staecker H et al (1993) Retinoic acid stimulates regeneration of mammalian auditory hair cells. Science 260:692-695. https://doi.org/10.1126/science.8480180

363. Herrmann K (1995) Teratogenic effects of retinoic acid and related substances on the early development of the zebrafish (Brachydanio rerio) as assessed by a novel scoring system. Toxicol In Vitro 9:267-283. https ://doi.org/10.1016/0887-2333(95)00012-W

364. Deltour L, Ang HL, Duester G (1996) Ethanol inhibition of retinoic acid synthesis as a potential mechanism for fetal alcohol syndrome. FASEB J 10:1050-1057. https://doi.org/10.1096/fasebj.10.9.8801166

365. Kumar A, LaVoie H, DiPette D, Singh U (2013) Ethanol neurotoxicity in the developing cerebellum: underlying mechanisms and implications. Brain Sci 3:941-963. https://doi.org/10.3390/brainsci3020941

366. Dickman ED, Thaller C, Smith SM (1997) Temporally-regulated retinoic acid depletion produces specific neural crest, ocular and nervous system defects. Development 124:3111-3121

367. Mic FA, Molotkov A, Molotkova N, Duester G (2004) Raldh2 expression in optic vesicle generates a retinoic acid signal needed for invagination of retina during optic cup formation. Dev Dyn 231:270-277. https://doi. org/10.1002/dvdy.20128

368. Abbott BD, Harris MW, Birnbaum LS (1989) Etiology of retinoic acidinduced cleft palate varies with the embryonic stage. Teratology 40:533-553. https://doi.org/10.1002/tera.1420400602

369. Lammer EJ, Chen DT, Hoar RM et al (1985) Retinoic acid embryopathy. N Engl J Med 313:837-841. https://doi.org/10.1056/NEJM19851003313 1401

370. Jacobs H, Dennefeld C, Féret B et al (2011) Retinoic acid drives aryl hydrocarbon receptor expression and is instrumental to dioxininduced toxicity during palate development. Environ Health Perspect 119:1590-1595. https://doi.org/10.1289/ehp.1003075

371. Okano J, Udagawa J, Shiota K (2014) Roles of retinoic acid signaling in normal and abnormal development of the palate and tongue. Congenital Anomalies 54:69-76. https://doi.org/10.1111/cga.12049

372. Baker NC, Sipes NS, Franzosa J et al (2020) Characterizing cleft palate toxicants using ToxCast data, chemical structure, and the biomedical literature. Birth Defects Res 112:19-39. https://doi.org/10.1002/bdr2.1581

373. Marklund M, Sjodal M, Beehler BC et al (2004) Retinoic acid signalling specifies intermediate character in the developing telencephalon. Development 131:4323-4332. https://doi.org/10.1242/dev.01308

374. Luo T, Wagner E, Grün F, Dräger UC (2004) Retinoic acid signaling in the brain marks formation of optic projections, maturation of the dorsal telencephalon, and function of limbic sites. J Comparative Neurol 470:297-316. https://doi.org/10.1002/cne.20013 
375. McCaffery P, Drager UC (1994) High levels of a retinoic acid-generating dehydrogenase in the meso- telencephalic dopamine system. Proc Natl Acad Sci USA 91:7772-7776. https://doi.org/10.1073/pnas.91.16.7772

376. Smith D, Wagner E, Koul O, et al (2001) Retinoic acid synthesis for the developing telencephalon. Cerebral cortex (New York, NY : 1991) 11:894-905. https://doi.org/10.1093/cercor/11.10.894

377. Rajaii F, Bitzer ZT, Xu Q, Sockanathan S (2008) Expression of the dominant negative retinoid receptor, RAR403, alters telencephalic progenitor proliferation, survival, and cell fate specification. Developmental Biology 316:371-382. https://doi.org/10.1016/j.ydbio.2008.01.041

378. Zhang J, Smith D, Yamamoto M et al (2003) The meninges is a source of retinoic acid for the late-developing hindbrain. J Neurosci 23:76107620. https://doi.org/10.1523/JNEUROSCI.23-20-07610.2003

379. Romand R, Kondo T, Cammas L et al (2008) Dynamic expression of the retinoic acid-synthesizing enzyme retinol dehydrogenase 10 (rdh10) in the developing mouse brain and sensory organs. J Comparative Neurol 508:879-892. https://doi.org/10.1002/cne.21707

380. Chatzi C, Brade T, Duester G (2011) Retinoic acid functions as a key GABAergic differentiation signal in the basal ganglia. PLoS Biol 9:e1000609. https://doi.org/10.1371/journal.pbio.1000609

381. Misner DL, Jacobs S, Shimizu Y et al (2001) Vitamin A deprivation results in reversible loss of hippocampal long-term synaptic plasticity. Proc Natl Acad Sci USA 98:11714-11719. https://doi.org/10.1073/pnas.19136 9798

382. Wietrzych M, Meziane $H$, Sutter A et al (2005) Working memory deficits in retinoid $X$ receptor $\gamma$-deficient mice. Learning and Memory 12:318-326. https://doi.org/10.1101//m.89805

383. Silva AJ (2003) Molecular and cellular cognitive studies of the role of synaptic plasticity in memory. J Neurobiol 54:224-237

384. Husson M, Enderlin V, Delacourte A et al (2006) Retinoic acid normalizes nuclear receptor mediated hypo-expression of proteins involved in $\beta$-amyloid deposits in the cerebral cortex of vitamin A deprived rats. Neurobiol Dis 23:1-10. https://doi.org/10.1016/j.nbd.2006.01.008

385. Maury CPJ, Teppo AM (1987) Immunodetection of protein composition in cerebral amyloid extracts in Alzheimer's disease: enrichment of retinol-binding protein. J Neurol Sci 80:221-228. https://doi. org/10.1016/0022-510X(87)90156-0

386. Saga Y, Kobayashi M, Ohta H et al (1999) Impaired extrapyramidal function caused by the targeted disruption of Retinoid X receptor RXRY1 isoform. Genes Cells 4:219-228. https://doi.org/10.104 6/j.1365-2443.1999.00253.x

387. Pan JB, Monteggia LM, Giordano T (1993) Altered levels and splicing of the amyloid precursor protein in the adult rat hippocampus after treatment with DMSO or retinoic acid. Brain Res Mol Brain Res 18:259-266. https://doi.org/10.1016/0169-328x(93)90198-x

388. Yoshikawa K, Aizawa T, Hayashi Y (1992) Degeneration in vitro of postmitotic neurons overexpressing the Alzheimer amyloid protein precursor. Nature 359:64-67. https://doi.org/10.1038/359064a0

389. Iñiguez MA, Morte B, Rodriguez-Peña A et al (1994) Characterization of the promoter region and flanking sequences of the neuron-specific gene RC3 (neurogranin). Mol Brain Res 27:205-214. https://doi. org/10.1016/0169-328X(94)90002-7

390. Wang YZ, Christakos S (1995) Retinoic acid regulates the expression of the calcium binding protein, calbindin-D28k. Mol Endocrinol 9:1510-1521. https://doi.org/10.1210/mend.9.11.8584029

391. Hernández-Pinto AM, Puebla-Jiménez L, Arilla-Ferreiro E (2006) A vitamin A-free diet results in impairment of the rat hippocampal somatostatinergic system. Neuroscience 141:851-861. https://doi. org/10.1016/j.neuroscience.2006.04.034

392. Berse B, Blusztajn JK (1995) Coordinated up-regulation of choline acetyltransferase and vesicular acetylcholine transporter gene expression by the retinoic acid receptor a, CAMP, and leukemia inhibitory factor/ciliary neurotrophic factor signaling pathways in a murine septal cell lin. J Biol Chem 270:22101-22104. https://doi.org/10.1074/ jbc.270.38.22101

393. Bonnet E, Touyarot K, Alfos S et al (2008) Retinoic acid restores adult hippocampal neurogenesis and reverses spatial memory deficit in vitamin A deprived rats. PLoS ONE 3:e3487. https://doi.org/10.1371/ journal.pone.0003487

394. Haskell GT, LaMantia AS (2005) Retinoic acid signaling identifies a distinct precursor population in the developing and adult forebrain. J Neurosci 25:7636-7647. https://doi.org/10.1523/JNEUR OSCI.0485-05.2005

395. Tafti M, Ghyselinck NB (2007) Functional implication of the vitamin A signaling pathway in the brain. Arch Neurol 64:1706-1711. https://doi. org/10.1001/archneur.64.12.1706

396. Audouin-Chevallier I, Pallet V, Coustaut M et al (1995) Retinoids modulate the binding capacity of the glucocorticoid receptor and its translocation from cytosol to nucleus in liver cells. J Steroid Biochem Mol Biol 52:321-328. https://doi.org/10.1016/0960-0769094)00184-n

397. Krężel W, Kastner P, Chambon P (1999) Differential expression of retinoid receptors in the adult mouse central nervous system. Neuroscience 89:1291-1300. https://doi.org/10.1016/s0306-4522(98)00342-x

398. Zetterström RH (1999) Role of retinoids in the CNS: differential expression of retinoid binding proteins and receptors and evidence for presence of retinoic acid. Eur J Neurosci 11:407-416. https://doi.org/10.104 6/j.1460-9568.1999.00444.x

399. Holson RR, Adams J, Ferguson SA (1999) Gestational stage-specific effects of retinoic acid exposure in the rat. Neurotoxicol Teratol 21:393-402. https://doi.org/10.1016/s0892-0362(99)00007-0

400. Maynard TM, Sikich L, Lieberman JA, LaMantia A-S (2001) Neural Development, Cell-Cell Signaling, and the "Two-Hit" Hypothesis of Schizophrenia. Schizophr Bull 27:457-476. https://doi.org/10.1093/ oxfordjournals.schbul.a006887

401. Palha JA, Goodman AB (2006) Thyroid hormones and retinoids: a possible link between genes and environment in schizophrenia. Brain Res Rev 51:61-71. https://doi.org/10.1016/j.brainresrev.2005.10.001

402. Krauss JK, Mohadjer M, Wakhloo AK, Mundinger F (1991) Dystonia and akinesia due to pallidoputaminal lesions after disulfiram intoxication. Mov Disord 6:166-170. https://doi.org/10.1002/mds.870060214

403. Laplane D, Attal N, Sauron B et al (1992) Lesions of basal ganglia due to disulfiram neurotoxicity. J Neurol Neurosurg Psychiatry 55:925-929

404. Husson M, Enderlin V, Alfos S et al (2004) Expression of neurogranin and neuromodulin is affected in the striatum of vitamin A-deprived rats. Mol Brain Res 123:7-17. https://doi.org/10.1016/j.molbrainre s.2003.12.012

405. Haskell GT, Maynard TM, Shatzmiller RA, Lamantia AS (2002) Retinoic acid signaling at sites of plasticity in the mature central nervous system. J Comparative Neurol 452:228-241. https://doi.org/10.1002/cne.10369

406. Wendling O, Dennefeld C, Chambon P, Mark M (2000) Retinoid signaling is essential for patterning the endoderm of the third and fourth pharyngeal arches. Development 127:1553-1562

407. Heine Ul, Roberts AB, Munoz EF et al (1986) Effects of retinoid deficiency on the development of the heart and vascular system of the quail embryo. Virchows Archiv B Cell Pathol Mol Patholgy 50:135-152. https://doi.org/10.1007/BF02889897

408. Niederreither K, Vermot J, Le Roux I et al (2003) The regional pattern of retinoic acid synthesis by RALDH2 is essential for the development of posterior pharyngeal arches and the enteric nervous system. Development 130:2525-2534

409. Guris DL, Duester G, Papaioannou VE, Imamoto A (2006) Dose-dependent interaction of Tbx1 and Crkl and locally aberrant RA signaling in a model of del22q11 syndrome. Dev Cell 10:81-92. https://doi. org/10.1016/j.devcel.2005.12.002

410. Ryckebusch L, Bertrand N, Mesbah Ket al (2010) Decreased levels of embryonic retinoic acid synthesis accelerate recovery from arterial growth delay in a mouse model of DiGeorge syndrome. Circ Res 106:686-694. https://doi.org/10.1161/CIRCRESAHA.109.205732

411. Golzio C, Martinovic-Bouriel J, Thomas S et al (2007) Matthew-Wood syndrome is caused by truncating mutations in the retinol-binding protein receptor gene STRA6. Am J Hum Genet 80:1179-1187. https:// doi.org/10.1086/518177

412. Pasutto F, Sticht H, Hammersen G et al (2007) Mutations in STRA6 cause a broad spectrum of malformations including anophthalmia, congenital heart defects, diaphragmatic hernia, alveolar capillary dysplasia, lung hypoplasia, and mental retardation. Am J Hum Genet 80:550-560. https ://doi.org/10.1086/512203

413. Roberts C, Ivins S, Cook AC et al (2006) Cyp26 genes a1, b1 and C1 are down-regulated in Tbx1 null mice and inhibition of Cyp26 enzyme function produces a phenocopy of DiGeorge Syndrome in the chick. Hum Mol Genet 15:3394-3410. https://doi.org/10.1093/hmg/ddl416 
414. Keegan BR, Feldman JL, Begemann G et al (2005) Retinoic acid signaling restricts the cardiac progenitor pool. Science 307:247-249. https:// doi.org/10.1126/science.1101573

415. Bilbija D, Haugen F, Sagave J et al (2012) Retinoic acid signalling is activated in the postischemic heart and may influence remodelling. PLoS ONE 7:e44740. https://doi.org/10.1371/journal.pone.0044740

416. Merki E, Zamora M, Raya A et al (2005) Epicardial retinoid X receptor $a$ is required for myocardial growth and coronary artery formation. Proc Natl Acad Sci USA 102:18455-18460. https://doi.org/10.1073/ pnas.0504343102

417. Stainier DYR, Fishman MC (1992) Patterning the zebrafish heart tube: acquisition of anteroposterior polarity. Develop Biol 153:91-101. https ://doi.org/10.1016/0012-1606(92)90094-W

418. Stainier DYR (2001) Zebrafish genetics and vertebrate heart formation. Nat Rev Genet 2:39-48

419. Huang S, Ma J, Liu X et al (2011) Retinoic acid signaling sequentially controls visceral and heart laterality in zebrafish. J Biol Chem 286:28533-28543. https://doi.org/10.1074/jbc.M111.244327

420. Moss JB, Xavier-Neto J, Shapiro MD et al (1998) Dynamic patterns of retinoic acid synthesis and response in the developing mammalian heart. Develop Biol 199:55-71. https://doi.org/10.1006/dbio.1998.891

421. Yutzey KE, Bader D (1995) Diversification of cardiomyogenic cell lineages during early heart development. Circ Res 77:216-219. https://doi. org/10.1161/01.RES.77.2.216

422. Mark M, Ghyselinck NB, Chambon P (2006) Function of retinoid nuclear receptors: lessons from genetic and pharmacological dissections of the retinoic acid signaling pathway during mouse embryogenesis. Annu Rev Pharmacol Toxicol 46:451-480. https://doi.org/10.1146/annur ev.pharmtox.46.120604.141156

423. Ratajska A, Złotorowicz R, Błażejczyk M, Wasiutyñski A (2005) Coronary artery embryogenesis in cardiac defects induced by retinoic acid in mice. Birth Defects Res A 73:966-979. https://doi.org/10.1002/ bdra.20200

424. Yasui H, Nakazawa M, Morishima M et al (1995) Morphological observations on the pathogenetic process of transposition of the great arteries induced by retinoic acid in mice. Circulation 91:2478-2486. https://doi. org/10.1161/01.cir.91.9.2478

425. Hochgreb T, Linhares VL, Menezes DC et al (2003) A caudorostral wave of RALDH2 conveys anteroposterior information to the cardiac field. Development 130:5363-5374. https://doi.org/10.1242/dev.00750

426. Isales GM, Hipszer RA, Raftery TD et al (2015) Triphenyl phosphateinduced developmental toxicity in zebrafish: potential role of the retinoic acid receptor. Aquat Toxicol 161:221-230. https://doi. org/10.1016/j.aquatox.2015.02.009

427. De Carlo Massaro G, Massaro D (1997) Retinoic acid treatment abrogates elastase-induced pulmonary emphysema in rats. Nat Med 3:675-677. https://doi.org/10.1038/nm0697-675

428. Desai TJ, Chen F, Lü J et al (2006) Distinct roles for retinoic acid receptors alpha and beta in early lung morphogenesis. Develop Biol 291:12-24 https://doi.org/10.1016/j.ydbio.2005.10.045

429. Desai TJ, Malpel S, Flentke GR et al (2004) Retinoic acid selectively regulates Fgf10 expression and maintains cell identity in the prospective lung field of the developing foregut. Develop Biol 273:402-415. https:// doi.org/10.1016/j.ydbio.2004.04.039

430. Chen F, Cao Y, Qian J et al (2010) A retinoic acid-dependent network in the foregut controls formation of the mouse lung primordium. J Clin Investig 120:2040-2048. https://doi.org/10.1172/JCl40253

431. Wang Z, Dollé P, Cardoso WV, Niederreither K (2006) Retinoic acid regulates morphogenesis and patterning of posterior foregut derivatives. Develop Biol 297:433-445. https://doi.org/10.1016/j.ydbio.2006.05.019

432. Rankin SA, Han L, McCracken KW et al (2016) A retinoic acid-hedgehog cascade coordinates mesoderm-inducing signals and endoderm competence during lung specification. Cell Reports 16:66-78. https:// doi.org/10.1016/j.celrep.2016.05.060

433. Pederiva F, Martinez L, Tovar JA (2012) Retinoic acid rescues deficient airway innervation and peristalsis of hypoplastic rat lung explants. Neonatology 101:132-139. https://doi.org/10.1159/000329613

434. Yun EJ, Lorizio W, Seedorf G et al (2016) VEGF and endothelium-derived retinoic acid regulate lung vascular and alveolar development. Am J Physiol Lung Cell Mol Physiol 310:L287-L298. https://doi.org/10.1152/ ajplung.00229.2015
435. Chen Y, Pan FC, Brandes N et al (2004) Retinoic acid signaling is essential for pancreas development and promotes endocrine at the expense of exocrine cell differentiation in Xenopus. Develop Biol 271:144-160. https://doi.org/10.1016/j.ydbio.2004.03.030

436. Stafford D, Prince VE (2002) Retinoic acid signaling is required for a critical early step in zebrafish pancreatic development. Curr Biol 12:1215-1220. https://doi.org/10.1016/S0960-9822(02)00929-6

437. Kinkel MD, Prince VE (2009) On the diabetic menu: zebrafish as a model for pancreas development and function. BioEssays 31:139-152

438. Kinkel MD, Eames SC, Alonzo MR, Prince VE (2008) Cdx4 is required in the endoderm to localize the pancreas and limit $\beta$-cell number. Development 135:919-929. https://doi.org/10.1242/dev.010660

439. Ostrom M, Loffler KA, Edfalk S et al (2008) Retinoic acid promotes the generation of pancreatic endocrine progenitor cells and their further differentiation into $\beta$-cells. PLoS ONE 3:e2841. https://doi.org/10.1371/ journal.pone.0002841

440. Alexa K, Choe SK, Hirsch N et al (2009) Maternal and zygotic aldh1a2 activity is required for pancreas development in zebrafish. PLoS ONE. 4:e8261. https://doi.org/10.1371/journal.pone.0008261

441. Martín M, Gallego-Llamas J, Ribes V et al (2005) Dorsal pancreas agenesis in retinoic acid-deficient Raldh2 mutant mice. Developmental Biology 284:399-411. https://doi.org/10.1016/j.ydbio.2005.05.035

442. Kinkel MD, Sefton EM, Kikuchi Y et al (2009) Cyp26 enzymes function in endoderm to regulate pancreatic field size. Proc Natl Acad Sci USA 106:7864-7869. https://doi.org/10.1073/pnas.0813108106

443. Serluca FC, Fishman MC (2001) Pre-pattern in the pronephric kidney field of zebrafish. Development 128:2233-2241

444. Cartry J, Nichane M, Ribes V et al (2006) Retinoic acid signalling is required for specification of pronephric cell fate. Develop Biol 299:35-51. https://doi.org/10.1016/j.ydbio.2006.06.047

445. Mendelsohn C, Lohnes D, Decimo D et al (1994) Function of the retinoic acid receptors (RARs) during development. (II) Multiple abnormalities at various stages of organogenesis in RAR double mutants. Development 120:2749-2771

446. Osafune K, Nishinakamura R, Komazaki S (2002) In vitro induction of the pronephric duct in Xenopus explants. Dev Growth Differ 44:161-167. https://doi.org/10.1046/j.1440-169x.2002.00631.x

447. Wingert RA, Selleck R, Yu J et al (2007) The cdx genes and retinoic acid control the positioning and segmentation of the zebrafish pronephros. PLoS Genet 3:1922-1938. https://doi.org/10.1371/journal.pgen.00301 89

448. Rosselot C, Spraggon L, Chia I et al (2010) Non-cell-autonomous retinoid signaling is crucial for renal development. Development 137:283-292. https://doi.org/10.1242/dev.040287

449. Gray SP, Cullen-McEwen LA, Bertram JF, Moritz KM (2012) Mechanism of alcohol-induced impairment in renal development: could it be reduced by retinoic acid? Clin Exp Pharmacol Physiol 39:807-813. https://doi.org /10.1111/j.1440-1681.2011.05597.x

450. Kot-Leibovich H, Fainsod A (2009) Ethanol induces embryonic malformations by competing for retinaldehyde dehydrogenase activity during vertebrate gastrulation. DMM Dis Models Mech 2:295-305. https ://doi.org/10.1242/dmm.001420

451. Zuniga A (2015) Next generation limb development and evolution: old questions, new perspectives. Development (Cambridge) 142:3810 3820. https://doi.org/10.1242/dev.125757

452. Probst S, Kraemer C, Demougin P et al (2011) SHH propagates distal limb bud development by enhancing CYP26B1-mediated retinoic acid clearance via AER-FGF signalling. Development 138:1913-1923. https:// doi.org/10.1242/dev.063966

453. Mohanty-Hejmadi P, Dutta SK, Mahapatra P (1992) Limbs generated at site of tail amputation in marbled balloon frog after vitamin A treatment. Nature 355:352-353. https://doi.org/10.1038/355352a0

454. Niazi IA, Ratnasamy CS (1984) Regeneration of whole limbs in toad tadpoles treated with retinol palmitate after the wound-healing stage. Exp Zool 230:501-505. https://doi.org/10.1002/jez.1402300320

455. Niazi IA, Saxena S (1978) Abnormal hind limb regeneration in tadpoles of the toad, Bufo andersoni, exposed to excess vitamin A. Folia Biol 26:3-8

456. Viviano CM, Horton CE, Maden M, Brockes JP (1995) Synthesis and release of 9 -cis retinoic acid by the urodele wound epidermis. Development 121:3753-3762 
457. Maden M (1993) The homeotic transformation of tails into limbs in Rana temporaria by retinoids. Develop Biol 159:379-391. https://doi. org/10.1006/dbio.1993.1249

458. Thaller C, Eichele G (1987) Identification and spatial distribution of retinoids in the developing chick limb bud. Nature 327:625-628. https ://doi.org/10.1038/327625a0

459. Stratford T, Horton C, Maden M (1996) Retinoic acid is required for the initiation of outgrowth in the chick limb bud. Curr Biol 6:1124-1133. https://doi.org/10.1016/S0960-9822(02)70679-9

460. Brent GA, Dunn MK, Harney JW et al (1989) Thyroid hormone aporeceptor represses T3-inducible promoters and blocks activity of the retinoic acid receptor. New Biol 1:329-336

461. Koide T, Downes M, Chandraratna RASS et al (2001) Active repression of RAR signaling is required for head formation. Genes Dev 15:2111-2121. https://doi.org/10.1101/gad.908801

462. Weston AD, Blumberg B, Underhill TM (2003) Active repression by unliganded retinoid receptors in development: less is sometimes more. J Cell Biol 161:223-228. https://doi.org/10.1083/jcb.200211117

463. Astapova I, Lee LJ, Morales C et al (2008) The nuclear corepressor, NCoR, regulates thyroid hormone action in vivo. Proc Natl Acad Sci USA 105:19544-19549. https://doi.org/10.1073/pnas.0804604105

464. Verhaegen Y, Parmentier K, Swevers L et al (2011) The heterodimeric ecdysteroid receptor complex in the brown shrimp Crangon crangon: ecR and RXR isoform characteristics and sensitivity towards the marine pollutant tributyltin. Gen Comp Endocrinol 172:158-169. https://doi. org/10.1016/j.ygcen.2011.02.019

465. Thummel CS (1995) From embryogenesis to metamorphosis: the regulation and function of drosophila nuclear receptor superfamily members. Cell 83:871-877. https://doi.org/10.1016/0092-8674(95)90203-1

466. Ghbeish N, Tsai CC, Schubiger M et al (2001) The dual role of ultraspiracle, the Drosophila retinoid $X$ receptor, in the ecdysone response. Proc Natl Acad Sci USA 98:3867-3872. https://doi.org/10.1073/pnas.06143 7798

467. Ollikainen N, Chandsawangbhuwana C, Baker ME (2006) Evolution of the thyroid hormone, retinoic acid, ecdysone and liver $\mathrm{X}$ receptors. Integr Comp Biol 46:815-826. https://doi.org/10.1093/icb/icl035

468. Héral M, Alzieu C, Deslous-Paoli J-M (1989) Effect of organotin compounds (TBT) used in antifouling paints on cultured marine molluscs - a literature study. In: Pauw D, Jaspers E, Ackefors H, Wilkins N (eds) Aquaculture - a biotechnology in progress. European Aquaculture Society, Bredene, Belgium, pp 1081-1089

469. Lima D, Reis-Henriques MA, Silva R et al (2011) Tributyltin-induced imposex in marine gastropods involves tissue-specific modulation of the retinoid $X$ receptor. Aquat Toxicol 101:221-227. https://doi. org/10.1016/j.aquatox.2010.09.022

470. Vogeler S, Galloway TS, Isupov M, Bean TP (2017) Cloning retinoid and peroxisome proliferator-activated nuclear receptors of the Pacific oyster and in silico binding to environmental chemicals. PLOS ONE 12:e0176024. https://doi.org/10.1371/journal.pone.0176024

471. Nishikawa Jl, Mamiya S, Kanayama T et al (2004) Involvement of the retinoid $X$ receptor in the development of imposex caused by organotins in gastropods. Environ Sci Technol 38:6271-6276. https:// doi.org/10.1021/es049593u

472. Castro LFC, Lima D, Machado A et al (2007) Imposex induction is mediated through the Retinoid X Receptor signalling pathway in the neogastropod Nucella lapillus. Aquat Toxicol 85:57-66. https://doi. org/10.1016/j.aquatox.2007.07.016

473. Sternberg RM, Hotchkiss AK, Leblanc GA (2008) Synchronized expression of retinoid $X$ receptor $m R N A$ with reproductive tract recrudescence in an imposex-susceptible mollusc. Environ Sci Techno 42:1345-1351. https://doi.org/10.1021/es702381g

474. Lohnes D, Kastner P, Dierich A et al (1993) Function of retinoic acid receptor $\gamma$ in the mouse. Cell 73:643-658. https://doi.org/10.1016/00928674(93)90246-M

475. Busada JT, Geyer CB (2016) The role of retinoic acid (RA) in spermatogonial differentiation. Biol Reprod 94:1-10. https://doi.org/10.1095/biolr eprod.115.135145

476. Ogino Y, Suzuki K, Haraguchi R et al (2001) External genitalia formation: role of fibroblast growth factor, retinoic acid signaling, and distal urethral epithelium. Ann N Y Acad Sci 948:13-31
477. Liu L, Suzuki K, Nakagata N et al (2012) Retinoic acid signaling regulates sonic hedgehog and bone morphogenetic protein signalings during genital tubercle development. Birth Defects Res Part B Develop Reproductive Toxicol 95:79-88. https://doi.org/10.1002/bdrb.20344

478. Pennimpede T, Cameron DA, MacLean GA et al (2010) The role of CYP26 enzymes in defining appropriate retinoic acid exposure during embryogenesis. Birth Defects Res A 88:883-894. https://doi.org/10.1002/ bdra.20709

479. Eikel D, Lampen A, Nau H (2006) Teratogenic effects mediated by inhibition of histone deacetylases: evidence from quantitative structure activity relationships of 20 valproic acid derivatives. Chem Res Toxicol 19:272-278. https://doi.org/10.1021/tx0502241

480. Kultima K, Jergil M, Salter H et al (2010) Early transcriptional responses in mouse embryos as a basis for selection of molecular markers predictive of valproic acid teratogenicity. Reprod Toxicol 30:457-468. https:// doi.org/10.1016/j.reprotox.2010.05.014

481. Li ASWW, Marikawa Y (2016) Adverse effect of valproic acid on an in vitro gastrulation model entails activation of retinoic acid signaling. Reprod Toxicol 66:68-83. https://doi.org/10.1016/j.reprotox.2016.09.015

482. Nau H, Tzimas G, Mondry M et al (1995) Antiepileptic drugs alter endogenous retinoid concentrations: a possible mechanism of teratogenesis of anticonvulsant therapy. Life Sci 57:53-60. https://doi. org/10.1016/0024-3205(95)00242-X

483. Corcoran J, So PL, Barber RD et al (2002) Retinoic acid receptor $\beta 2$ and neurite outgrowth in the adult mouse spinal cord in vitro. J Cell Sci 115:3779-3786. https://doi.org/10.1242/jcs.00046

484. Corcoran J, So PL, Maden M (2002) Absence of retinoids can induce motoneuron disease in the adult rat and a retinoid defect is present in motoneuron disease patients. J Cell Sci 115:4735-4741. https://doi. org/10.1242/jcs.00169

485. Malaspina A, Kaushik N, De Belleroche J (2001) Differential expression of 14 genes in amyotrophic lateral sclerosis spinal cord detected using gridded cDNA arrays. J Neurochem 77:132-145. https://doi.org/10.104 6/j.1471-4159.2001.00231.x

486. Jiang YM, Yamamoto M, Kobayashi Y et al (2005) Gene expression profile of spinal motor neurons in sporadic amyotrophic lateral sclerosis. Ann Neurol 57:236-251. https://doi.org/10.1002/ana.20379

487. Holson RR, Adams J, Ferguson SA, Scalzo FM (2000) Retinoic acid exposure on gestational days 11 to 13 impairs swallowing in rat offspring. Neurotoxicol Teratol 22:541-545. https://doi.org/10.1016/s0892 -0362(00)00072-6

488. Holson RR, Cogan JE, Adams J (2001) Gestational retinoic acid exposure in the rat: effects of sex, strain and exposure period. Neurotoxicol Teratol 23:147-156. https://doi.org/10.1016/s0892-0362(01)00133-7

489. Coluccia A, Borracci P, Belfiore D et al (2009) Late embryonic exposure to all-trans retinoic acid induces a pattern of motor deficits unrelated to the developmental stage. NeuroToxicology 30:1120-1126. https://doi. org/10.1016/j.neuro.2009.08.002

490. Coluccia A, Belfiore D, Bizzoca A et al (2008) Gestational all-trans retinoic acid treatment in the rat: neurofunctional changes and cerebellar phenotype. Neurotoxicol Teratol 30:395-403. https://doi.org/10.1016/j. ntt.2008.03.064

491. Sahu B, Maeda A (2016) Retinol dehydrogenases regulate vitamin A metabolism for visual function. Nutrients 8:746. https://doi. org/10.3390/nu8110746

492. Fuchs E, Green H (1981) Regulation of terminal differentiation of cultured human keratinocytes by vitamin A. Cell 25:617-625. https://doi. org/10.1016/0092-8674(81)90169-0

493. Ross AC, Zolfaghari R, Weisz J (2001) Vitamin A: recent advances in the biotransformation, transport, and metabolism of retinoids. Curr Opin Gastroenterol 17:184-192

494. Wiseman EM, Bar-El Dadon S, Reifen R (2017) The vicious cycle of vitamin a deficiency: a review. Crit Rev Food Sci Nutr 57:3703-3714. https:// doi.org/10.1080/10408398.2016.1160362

495. Hall JA, Cannons JL, Grainger JR et al (2011) Essential role for retinoic acid in the promotion of $\mathrm{CD} 4+\mathrm{T}$ cell effector responses via retinoic acid receptor alpha. Immunity 34:435-447. https://doi.org/10.1016/j. immuni.2011.03.003

496. Bono MR, Tejon G, Flores-Santibañez F et al (2016) Retinoic acid as a modulator of T cell immunity. Nutrients. 8:349. https://doi.org/10.3390/ nu8060349 
497. Reay WR, Atkins JR, Quidé Y et al (2020) Polygenic disruption of retinoid signalling in schizophrenia and a severe cognitive deficit subtype. Molecular Psychiatry 25:719-731. https://doi.org/10.1038/s4138 0-018-0305-0

498. Takeda A, Nyssen OP, Syed A et al (2014) Vitamin A and carotenoids and the risk of Parkinson's Disease: a systematic review and meta-analysis. Neuroepidemiology 42:25-38. https://doi.org/10.1159/000355849

\section{Publisher's Note}

Springer Nature remains neutral with regard to jurisdictional claims in published maps and institutional affiliations.

\section{Submit your manuscript to a SpringerOpen ${ }^{\odot}$ journal and benefit from:}

- Convenient online submission

- Rigorous peer review

- Open access: articles freely available online

- High visibility within the field

- Retaining the copyright to your article

Submit your next manuscript at $\boldsymbol{\nabla}$ springeropen.com 